VILNIAUS GEDIMINO TECHNIKOS UNIVERSITETAS

Nomeda BRATČIKOVIENÉ

\title{
ŠALIES EKONOMIKOS INDIKATORIŲ DINAMIKOS MODELIS
}

DAKTARO DISERTACIJA

SOCIALINIAI MOKSLAI, EKONOMIKA (04S)

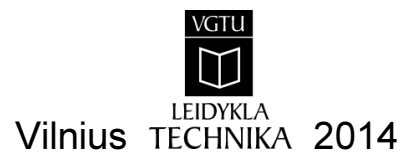


Disertacija rengta 2002-2014 metais Vilniaus Gedimino technikos universitete.

Disertacija ginama eksternu.

\section{Mokslinis konsultantas}

prof. habil. dr. Aleksandras Vytautas RUTKAUSKAS (Vilniaus Gedimino technikos universitetas, ekonomika - 04S).

\section{Mokslinis vadovas}

doc. dr. Bronislava KAMINSKIENE (Vilniaus Gedimino technikos universitetas, matematika-01P), (2002-2007).

Vilniaus Gedimino technikos universiteto Ekonomikos mokslo krypties disertacijos gynimo taryba:

\section{Pirmininkas}

prof. habil. dr. Romualdas GINEVIČIUS (Vilniaus Gedimino technikos universitetas, ekonomika-04S).

\section{Nariai:}

prof. dr. Meilutė JASIENĖ (Vilniaus universitetas, ekonomika - 04S), prof. dr. Natalja LACE (Rygos technikos universitetas, ekonomika - 04S), doc. dr. Marijus RADAVIČIUS (Vilniaus universitetas, matematika-01P), doc. dr. Jelena STANKEVIČIENE (Vilniaus Gedimino technikos universitetas, ekonomika-04S).

Disertacija bus ginama viešame Ekonomikos mokslo krypties disertacijos gynimo tarybos posėdyje $2014 \mathrm{~m}$. vasario 14 d. 13 val. Vilniaus Gedimino technikos universiteto senato posèdžių salejje.

Adresas: Saulètekio al. 11, LT-10223 Vilnius, Lietuva.

Tel.: (8 5) 274 4956; faksas (8 5) 270 0112; el. paštas doktor@vgtu.lt

Pranešimai apie numatomą ginti disertaciją išsiųsti $2014 \mathrm{~m}$. sausio $13 \mathrm{~d}$.

Disertaciją galima peržiūrèti interneto svetainèje http://dspace.vgtu.lt/ ir Vilniaus Gedimino technikos universiteto bibliotekoje (Sauletekio al. 14, LT-10223 Vilnius, Lietuva).

VGTU leidyklos TECHNIKA 2228-M mokslo literatūros knyga.

ISBN 978-609-457-618-8

(C) VGTU leidykla TECHNIKA, 2014

(C) Nomeda Bratčikovienè, 2014

nomeda.bratcikoviene@vgtu.lt 
VILNIUS GEDIMINAS TECHNICAL UNIVERSITY

Nomeda BRATČIKOVIENÉ

THE MODEL OF THE COUNTRY'S ECONOMIC INDICATORS DYNAMICS

DOCTORAL DISSERTATION

SOCIAL SCIENCES,

ECONOMICS (04S)

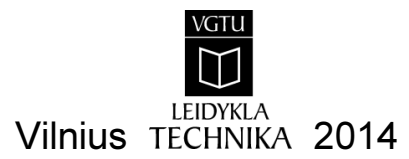


Doctoral dissertation was prepared at Vilnius Gediminas Technical University in 2002-2014.

The dissertation is defended as an external work.

\section{Scientific Consultant}

Prof Dr Habil Aleksandras Vytautas RUTKAUSKAS (Vilnius Gediminas Technical University, Economics - 04S).

\section{Scientific Supervisor}

Assoc Prof Dr Bronislava KAMINSKIENE (Vilnius Gediminas Technical University, Mathematics - 01P), (2002-2007).

The Dissertation Defense Council of Scientific Field of Economics of Vilnius Gediminas Technical University:

\section{Chairman}

Prof Dr Habil Romualdas GINEVIČIUS (Vilnius Gediminas Technical University, Economics - 04S).

\section{Members:}

Prof Dr Meilute JASIENE (Vilnius University, Economics - 04S),

Prof Dr Natalja LACE (Ryga Technical University, Economics - 04S), Assoc Prof Dr Marijus RADAVIČIUS (Vilnius University, Mathematics $-01 P)$,

Assoc Prof Dr Jelena STANKEVIČIENĖ (Vilnius Gediminas Technical University, Economics - 04S).

The dissertation will be defended at the public meeting of the Dissertation Defense Council of Economics in the Senate Hall of Vilnius Gediminas Technical University at 1 p. m. on 14 February 2014.

Address: Sauletekio al. 11, LT-10223 Vilnius, Lithuania.

Tel.: +370 5274 4956; fax +370 5270 0112; e-mail: doktor@vgtu.lt

A notification on the intend defending of the dissertation was send on 13 January 2014. A copy of the doctoral dissertation is available for review at the Internet website http://dspace.vgtu.lt/ and at the Library of Vilnius Gediminas Technical University (Sauletekio al. 14, LT-10223 Vilnius, Lithuania). 


\section{Reziumè}

Disertacijoje nagrinejjamos šalies pagrindinių ekonominių indikatorių modeliavimo galimybès, analizuojamos teorinès bei praktinès vertinimo prielaidos, šalies ūkio ypatumų sąlygojami apribojimai, tiriama Lietuvos bei užsienio šalių ekonominių modelių struktūra, šiuose modeliuose naudojamų ekonominiu indikatorių rinkiniai bei pasirinkti metodai. Norint gauti patikimus rezultatus, darbe atlikta ekonominio modeliavimo metodų lyginamoji analizè. Disertacijos tyrimų objektas - makroekonominių, verslo bei socialinių indikatorių laiko eilutès.

Pagrindinis disertacijoje keliamas darbo tikslas - sukurti pagrindinių šalies ekonomikos pokyčius matuojančių indikatorių dinamikos modelį, kuri naudojant galima kompleksiškai vertinti susiformavusių ekonominių indikatorių adekvatumą, jų suderinamumą bei tarpusavio sąveiką, tirti esamą šalies ekonominę būklę bei jos tvaruma, analizuoti atskirų ekonominių indikatorių pokyčių pasekmes ekonominei būsenai, kurti skirtingus ekonominius scenarijus bei ịvertinti šalies ūkio ekonominę perspektyvą.

Darbe sprendžiami pagrindinai uždaviniai: kuriamo šalies ekonomikos indikatorių dinamikos modelio struktūros bei teorinio pagrindimo nustatymas, tinkamų kompleksinio modeliavimo metodų parinkimas, modelio bei prognozių tikslumo ir stabilumo tyrimas, programinių priemonių sukūrimas.

Atlikus esamų ekonominio modeliavimo metodų analizę, disertacijos užsibrěžtiems tikslams pasiekti ir uždaviniams igyvendinti, buvo nuspręsta kurti naują šalies ekonominès būsenos ir perspektyvos vertinimo metodika, kuri leido pilniau atspindèti esamus ekonominius procesus.

Disertacija sudaro ivadas, trys skyriai, bendrosios išvados, naudotos literatūros šaltinių sąrašas, autorès publikacijų disertacijos tema sąrašas, santrauka anglų kalba. Ivade atskleidžiamas problemos aktualumas, formuluojamas darbo tikslas, uždaviniai, išryškinamas mokslinis bei praktinis darbo naujumas. Pirmame disertacijos skyriuje pateikta esamų Lietuvos bei užsienio ekonominių modelių apžvalga. Antrasis disertacijos skyrius skirtas šalies ekonomikos indikatorių modeliavimo metodikos parinkimui. Trečiame disertacijos skyriuje aprašyti teikiamos metodikos praktinio realizavimo rezultatai.

Disertacijos tema perskaityta dešimt pranešimų mokslinėse tarptautinėse bei šalies konferencijose ir paskelbtos devynios recenzuojamos mokslinės publikacijos: vienas straipsnis mokslo žurnale, itrauktame i ISI Web of Science duomenų bazę, penki - recenzuojamuose mokslo žurnaluose, trys - kituose recenzuojamuose mokslo leidiniuose. 


\section{Abstract}

The doctoral thesis investigates the opportunities for the modelling of leading county's economic indicators, analyses the theoretical and practical assumptions, the limitations conditioned by the country's economic features, studies the structure of economic models existing in Lithuania and foreign countries, the set of economic indicators used and selected methods of modelling. A comparative analysis of economic modelling methods was also carried out. The object of this research is the time series of macroeconomic, business and social indicators.

The goal of the work - to create the model of indicators that measure the country's economic dynamics, which enables the comprehensive assessment of the adequacy, coherence and interoperability of available economic indicators, the investigation and analysis of the current economic situation and its sustainability, the evaluation of the consequences of changes in certain economic indicators for the economic situation, the development of different economic scenarios, and the assessment of the country's economic prospects.

The main tasks solved in the work: determination of the structure and theoretical validity of the model of county's economic indicators dynamics, selection of appropriate comprehensive modelling methods, investigation of the accuracy and stability of the model and forecasts, development of software.

After an analysis of existing economic modelling methods, in order to achieve the objectives and goals of the thesis, it was decided to create a new methodology for the assessment of the country's economic situation and prospects, which enabled a more accurate and full reflection of the current economic processes.

The thesis consists of an introduction, three chapters, general conclusions, references, a list of the author's publications on the topic of the thesis, a summary in English. The introduction reveals the relevance of the problem, formulates the objective, tasks of the work, and highlights its scientific and practical novelty. The first chapter presents a broad review of the economic models existing in Lithuania and foreign countries. The second chapter is dedicated to the selection of a methodology for the modelling of county's economic indicators. The third chapter provides the results of the practical realisation of the methodology proposed.

Ten presentations on the topic of the thesis were made at scientific international and national conferences and nine reviewed scientific papers were published: one - in a scientific periodical journal included in the ISI Web of Science database, five - in reviewed scientific journals, three - other reviewed publications. 


\section{Žymèjimai}

\section{Simboliai}

$A(t)$ - bendrasis gamybos veiksnių našumas;

$B(t)$ - nacionalinio biudžeto pajamos;

$B^{m}(t)$ - mokestinès pajamos;

$B^{m}(t)$ - Europos Sajungos parama;

$C(t)$ - ciklo komponenté;

$D(t)$ - vidaus prekių paklausa;

$D P(t)$ - darbo pajamų kreditas;

$e(t)$ - eksportuota produkcija;

$E X(t)$ - eksportas;

$I(t)$ - investicijos;

$I M(t)$ - importas;

$I R(t)$ - atsitiktinè komponente;

$y(t)$ - analizuojama laiko eilute;

$Y(t)$ - pridètinè verté;

$Y_{L}(t)$ - viešojo valdymo ir gynybos, privalomojo socialinio draudimo sukurta pridètinè verte;

$K(t)$ - kapitalas;

$L(t)$ - darbas; 
$l(t)$ - pajamos;

$L S(t)$ - darbo pasiūla;

$M P(t)$ - mažmeninès prekybos ir maitinimo i̇monių apyvarta;

$P(t)$ - parduodamų prekių ar paslaugų kainos;

$P_{i}(t)$ - $i$-ojo gamybos išteklio kainos indeksas;

$P_{\text {exp }}(t)$ - eksporto kainų indeksas;

$P_{i m j}(t)-j$-tosios importuojamos prekès, prekių grupès ar paslaugų kainų indeksas.

$P^{e}(t)$ - tikètinas vartojimo prekių ir paslaugų kainų pokytis;

$p^{d}(t)$ - bendrojo vidaus produkto defliatorius;

$P_{G}(t)$ - gamintojų Lietuvos rinkoje parduotos produkcijos kainu indeksai;

$P_{V i}(t)-i$-tosios prekių ir paslaugų grupės vartotojų kainų indeksai,

$P A(t)$ - suteiktu paskolų apimtis;

$P B(t)$ - pinigu baze;

$P C(t)$ - privatus vartojimas;

$P N(t)$ - palūkanų norma;

$r c(t)$ - reali kapitalo kaina;

$S(t)$ - sezoninè komponente;

$T(t)$ - trendo komponente;

$T P(t)$ - technologinis progresas;

$T C(t)$ - trendo-ciklo komponente;

$U_{i}(t)$ - nestebimos laiko eilutès komponentès;

$U n(t)$ - nedarbo lygis

$V_{n}(t)$ - namų ūkių vartojimo išlaidos;

$V_{v}(t)$ - valdžios sektoriaus vartojimo išlaidos;

$Z(t)$ - gamybos kaštai;

$Q(t)$ - produkcija;

$W(t)$ - nominalus darbo užmokestis;

$w_{i}-i$-tosios prekès, prekių grupės ar paslaugos svoris vartojimo prekiu ir paslaugu krepšelyje;

$\widetilde{X}(t)$ - darbuotojų paklausa;

$\bar{X}(t)$ - įmonių ūkinès veiklos pelnas;

$X_{1}(t)$ - užimtujų skaičius;

$X_{2}(t)$ - faktiškai dirbtų valandų skaičius;

$X_{5}(t)$ - prekių ir paslaugų pardavimo pajamos;

$X_{7}(t)$ - nuosavas kapitalas;

$X_{8}(t)$ - parduota produkcija

$\prod(t)$ - darbo paklausa;

$\mu(t)$ - gamintojų marža;

$\eta$ - mažmenininkų marža;

$\xi(t)$ - realus valiutos kursas; 
$\bar{\xi}_{R U}(t)$ - lito ir Rusijos rublio santykis,

$\vec{\xi}_{P L}(t)$ - lito ir Lenkijos zloto santykis,

$\bar{\xi}_{L V}(t)$ - lito ir Latvijos lato santykis.

\section{Santrumpos}

ASETAR - adaptuotas slenkstinis autoregresinis metodas (angl. ASETAR - Adapted Self Exciting Threshold Autoregressive Model),

RESET - testas, naudojamas laiko eilučių netiesiškumui nustatyti (angl. RESET Ramsey Regression Equation Error Test),

VSAP - vidutinè santykinè absoliutinè paklaida,

VSKP - vidutinè santykinè kvadratinè paklaida,

SVKI - Suderintas vartotojų kainų indeksas. 



\section{Turinys}

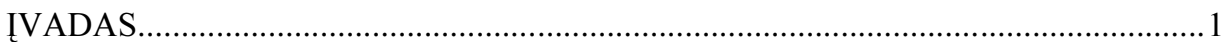

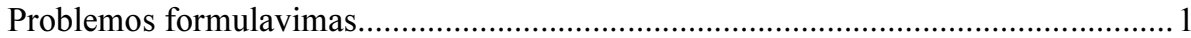

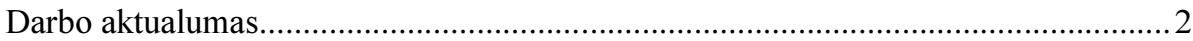

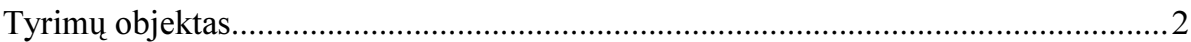

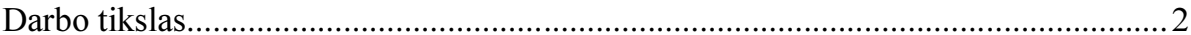

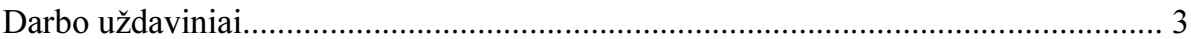

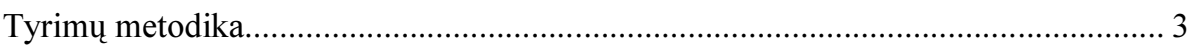

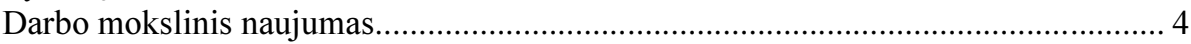

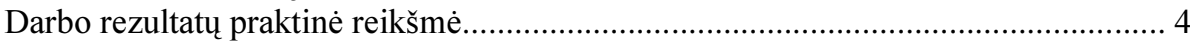

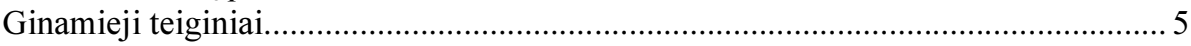

Darbo rezultatu aprobavimas................................................................................ 5

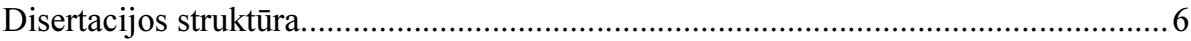

1. EKONOMETRINIO MODELIAVIMO APŽVALGA IR TIKSLAI.......................... 7

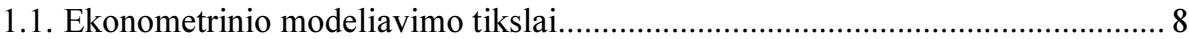

1.2. Trumpa ekonometrinio modeliavimo istorija................................................ 9

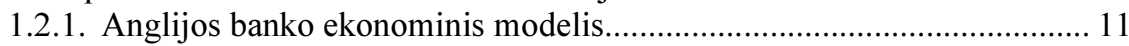

1.2.2. Austrijos makroekonominis modelis LIMA........................................... 12

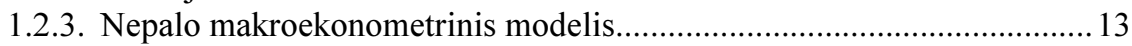

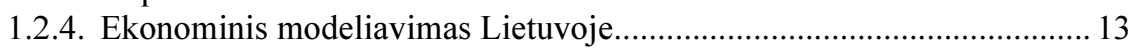

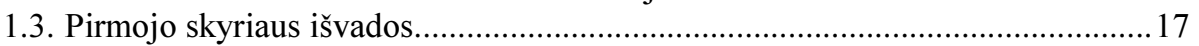


2. EKONOMETRIJOS ANATOMIJA. EKONOMINIŲ INDIKATORIU MODELIO

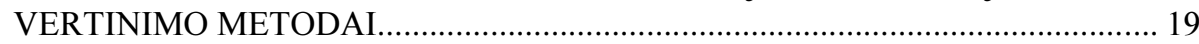

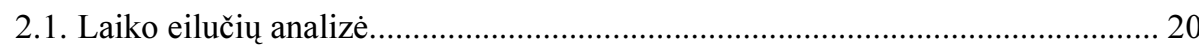

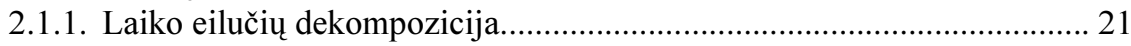

2.1.2. Laiko eilučių pirminė analizè ir koregavimas.......................................... 22

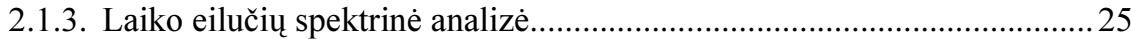

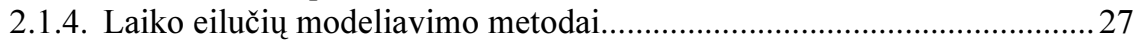

2.1.5. Laiko eilučiu nestebimų komponenčių vertinimo diagnostika................. 32

2.2. Autoregresiniai SETAR modeliai............................................................... 37

2.3. Modelio vertinimo pagrindimas: tyrimo metodika, algoritmai ir analizė........... 38

2.3.1. Laiko eilučių komponenčių nustatymo analizè.......................................... 39

2.3.2. Laiko eilučių nestebimų komponenčių vertinimo metodų lyginamoji

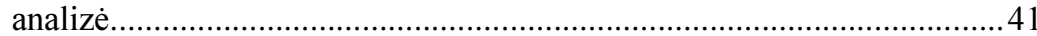

2.3.3. ASETAR modelis ir jo vertinimo algoritmas..........................................43

2.3.4. ASETAR ir ARIMA modelių lyginamoji analizè.................................... 49

2.3.5. Ekonominių indikatorių modelio lygčių sudarymo algoritmas..................52

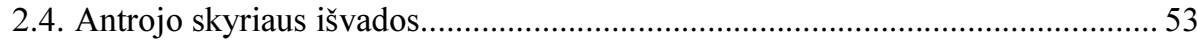

3. ŠALIES EKONOMIKOS INDIKATORIU DINAMIKOS MODELIO

ADEKVATUMO EMPIRINIS TYRIMAS LIETUVOS ATVEJU ...........................55

3.1. Modelio struktūra ir formavimo principai.......................................................56

3.1.1. Modelio lygčių formavimo principai ir specifikacija.................................57

3.1.2. Modelio lygčiu parametrų vertinimo eiga ir rezultatai...............................76

3.2. Siūlomos metodikos ir klasikinių modeliavimo metodų palyginimas................. 92

3.3. Priemonès šalies ūkio pokyčiu analizei..........................................................94

3.4. Trečiojo skyriaus išvados............................................................................... 97

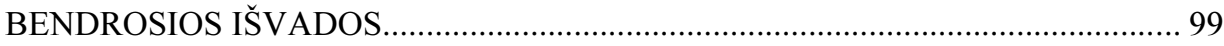

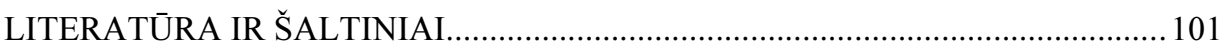

AUTORĖS MOKSLINIŲ PUBLIKACIJŲ DISERTACIJOS TEMA SĄRAŠAS..... 109

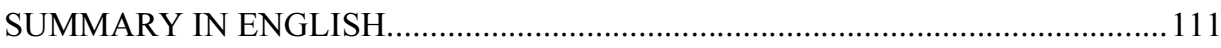

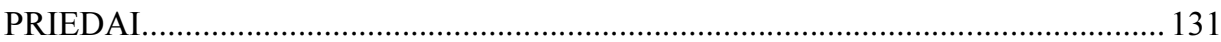

A priedas. Modeliuotų laiko eilučių nestebimų komponenčių vertinimo

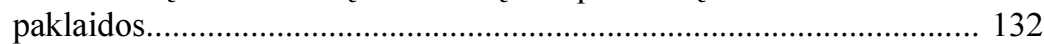

B priedas. Adaptuoto SETAR specifikacija......................................................... 134

C priedas. SETAR poklasiu keitimo grafikai........................................................ 137

D priedas. ASETAR ir ARIMA modeliu iverčiu grafikai...................................... 143

E priedas. SETAR ir ARIMA modelių paklaidų grafikai....................................... 148

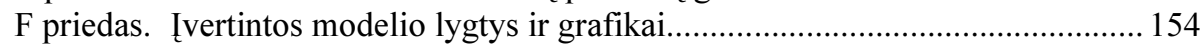

$\mathrm{G}$ priedas. Bendraautorių sutikimai teikti publikacijų medžiagą disertacijoje........ 184

$\mathrm{H}$ priedas. Autoriaus mokslinių publikacijų disertacijos tema kopijos..................... 185 


\section{Contents}

INTRODUCTION

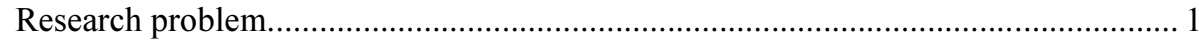

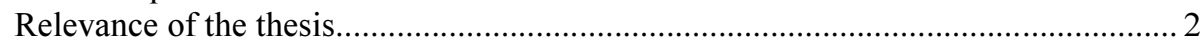

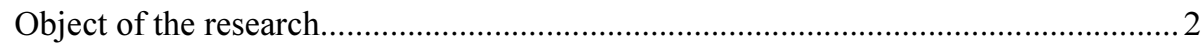

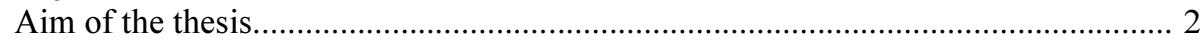

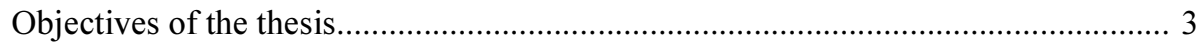

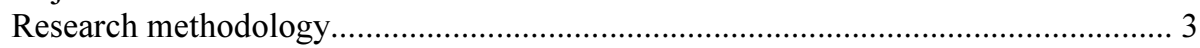

Scientific novelty of the thesis................................................................................ 4

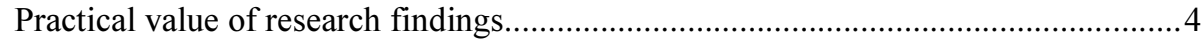

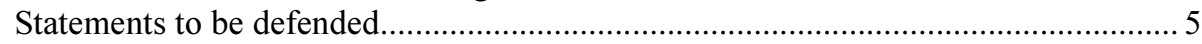

Approval of research findingd...........................................................................

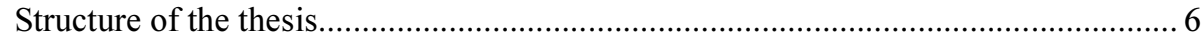

1. OVERVIEW AND PURPOSES OF ECONOMETRIC MODELLING.................... 7

1.1. Objectives of econometric modeling................................................................ 8

1.2. A short history of econometric modeling......................................................... 9

1.2.1. Economic model at the Bank of England.................................................. 11

1.2.2. The Macroeconometric Model LIMA for Austria......................................12

1.2.3. Nepal Macroeconometric Model .......................................................... 13

1.2.4. Modelling experience in Lithuania.......................................................... 13

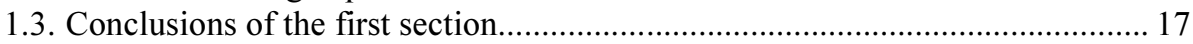




\section{ANATOMY OF ECONOMETRICS. METHODS FOR THE ASSESSMENT OF}

THE MODEL OF ECONOMIC INDICATORS................................................. 19

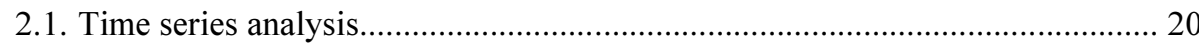

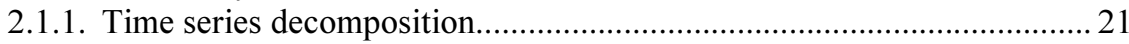

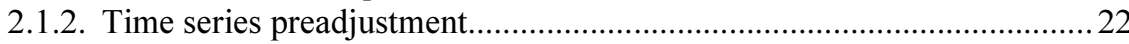

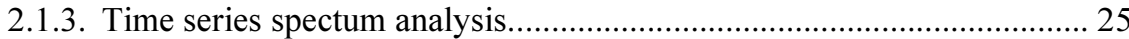

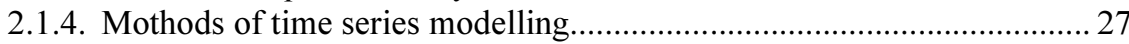

2.1.5. Diagnostic of unobserved time series components estimation................ 32

2.2. Autoregressive SETAR models.................................................................. 37

2.3. Validation of modelling assessment: research methodology, algorithms and

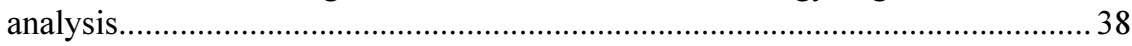

2.3.1. Analysis of time series component identification.................................... 39

2.3.2. Comparative analysis of time series unobserved components estimation

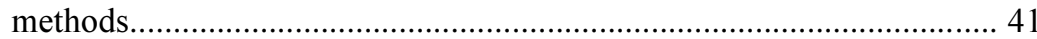

2.3.3. ASETAR model and its algorithm evaluation.......................................... 43

2.3.4. Comparative analysis of ASETAR and ARIMA models.......................... 49

2.3.5. Algorithm of the of the economic indicatos model equations

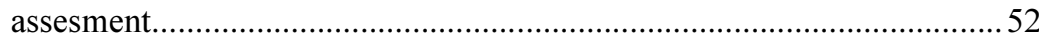

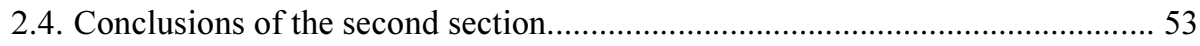

3. EMPIRICAL INVESTIGATION ON COUNTY'S ECONOMIC INDICATORS DYNAMICS MODEL ADEQUACY IN LITHUANIA.........................................55

3.1. Model structure and formation principles...................................................... 56

3.1.1. Formation principles and specifications of model equations...................57

3.1.2. Process and results of model parameters estimation............................... 76

3.2. Comparison of the proposed methodology and classical modelling methods... 92

3.3. Tools for country's economic development analysis.......................................... 94

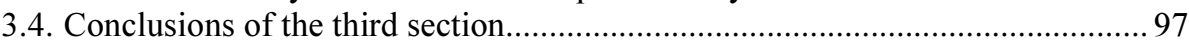

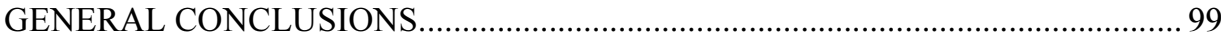

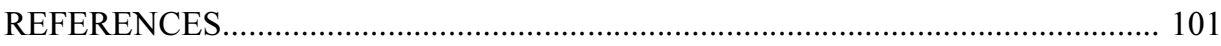

LIST OF THE AUTHOR'S SCIENTIFIC PUBLICATIONS ON THE THE TOPIC

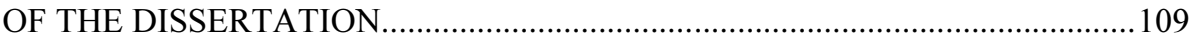

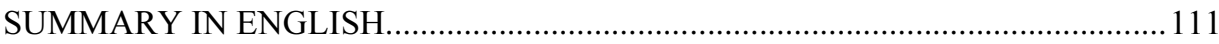

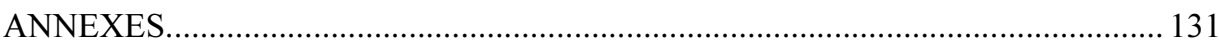

Annex A. Errors of estimated simulated time series unobserved components...... 132

Annex B. Specifications of adopted SETAR......................................................... 134

Annex C. SETAR regime switching graphs........................................................... 137

Annex D. The graphs of ASETAR and ARIMA models estimates......................... 143

Annex E. The graphs of SETAR and ARIMA models errors................................. 148

Annex F. Estimated model equations and graphs................................................ 154

Annex G. The coauthtors agreements to present publications in the dissertation.. 184

Annex H. Copies of scientific publications by the author on the topic of the dissertation. 


\section{Ivadas}

\section{Problemos formulavimas}

Ekonominiai modeliai kuriami nacionalinių ar tarptautinių ekonominių procesų analizei bei perspektyvos vertinimui, ekonominio tvarumo analizei, reakcijos $\mathfrak{i}$ vienokius ar kitokius ekonominius impulsus tyrimui, ekonomikos dèsningumų ir priklausomybių identifikavimui ir kalibravimui, prognozavimui ir valdymui reikalingos informacijos generavimui bei kiekybiniam priimamų sprendimų pagrindimui. Ekonominiai modeliai remiasi ekonometrinėmis ir/ar balansinėmis lygtimis bei tapatybėmis, aprašančiomis visuminę ekonomikos elgseną.

Daugelis pasaulio šalių ūkio analizei atlikti, ekonominių indikatorių prognozèms rengti, i̇vairiems ekonominiams scenarijams tikrinti naudoja ekonominius modelius. Ekonominių indikatorių modeliavimas yra ypač plačiai išvystytas Jungtinèse Amerikos Valstijose, Jungtinejje Karalysteje, Nyderlanduose bei Skandinavijos šalyse. Šių šalių ūkio ekonominis modeliavimas vyksta jau daug metų, o kadangi dažniausiai modeliai kuriami skirtingiems tikslams igyvendinti, tai kai kurios šalys turi net keletą tokių modelių.

Nors, skaičiuojant nuo nepriklausomybès atgavimo, Lietuvą galima laikyti pakankamai jaunos ekonomikos valstybe istoriniu požiūriu, tačiau per ši laikotarpi ivvyko nemažai esminių pokyčių visame Lietuvos ūkyje ekonominiu 
požiūriu: nuo planinès ekonomikos Lietuva perejo prie rinkos ekonomikos, susidūrè su hiperinfliacija ir aukštu nedarbo lygiu. Tvarumą igaunanti Lietuvos ekonomika pergyveno dvi ekonomines krizes, skaudžiai paveikusias Lietuvos ekonomikos vystymąsi. Dèl sparčiai besikeičiančių Lietuvos ekonominių sąlygų ir vis didesnio poreikio patikimoms ivvairių ekonominių indikatorių prognozėms bei šalies ūkio reakcijos į tam tikrus ekonominius pokyčius tyrimams, tikslinga sukurti šalies ekonomini modeli, kuris padètu parengti patikimas prognozes bei suteiktu galimybę priklausomai nuo įvairių prielaidu, sumodeliuoti skirtingus šalies ūkio elgsenos scenarijus.

\section{Darbo aktualumas}

Lietuvoje ekonominis modeliavimas vystomas jau senokai, tačiau dauguma ankstesnių viešai prieinamų Lietuvos ekonomikos tyrinejjimų buvo daugiausiai skirti konkrečių uždavinių sprendimui, o kurti modeliai vienalaikei platesnei ūkio analizei šiuo metu neatnaujinami ir dèl po pastaraisiais metais ivvykusių svarbių ekonomikos posūkių tapo nebeaktualūs ir nebepatikimi. Todèl reikalingas aktualus dabartinei Lietuvos ekonominei situacijai ekonominis modelis, apimantis visas Lietuvos ūkio ekonomines veiklas, kuri būtu galima taikyti šalies ūkio ekonominei būklei tirti ir vertinti, kiekybinei pagrindinių ekonominių indikatorių analizei atlikti, tolesnei ekonomikos plètrai prognozuoti, priimamų socialinių ir ekonominių sprendimų argumentavimui, skirtingų ekonominių scenarijų kūrimui.

\section{Tyrimų objektas}

Darbe tiriamos šalies makroekonominių (nacionalinių sąskaitu, valdžios sektoriaus finansų, investicijų, kainų ir užsienio prekybos), verslo (įmonių statistikos, pramonès, statybos ir vidaus prekybos) bei socialinès statistikos laiko eilutes, analizuojami matematiniai modeliai ir metodai, kuriu pagalba galima aprašyti ir prognozuoti šių laiko eilučių elgseną bei generuoti informacija, reikalingą ekonominio efektyvumo didinimui.

\section{Darbo tikslas}

Disertacijos tikslas - sukurti šalies ekonomiką matuojančių indikatorių dinamikos modelį, kuri naudojant galima tirti ir kompleksiškai vertinti ekonominių indikatorių adekvatuma, suderinamumą ir tarpusavio ryšius, atlikti 
atskirų indikatoriu pokyčiu itakos šalies ekonomikos būsenai vertinimus bei, naudojant skirtingas ekonomines prielaidas, prognozuoti šalies ūkio pagrindinius ekonominius indikatorius.

\section{Darbo uždaviniai}

Darbo tikslui igyvendinti ir mokslinei problemai spręsti disertaciniame darbe buvo iškelti šie uždaviniai:

1. Išanalizuoti šalies ekonominio modeliavimo patirti Lietuvoje, kitų šalių ekonominių modeliu taikymo galimybes bei nustatyti teorines ir praktines modeliavimo prielaidas, kuriant šalies ekonomikos indikatorių dinamikos modeli.

2. Nustatyti kuriamo šalies ekonomikos indikatorių dinamikos modelio struktūrą ir teorinị pagrindimą.

3. Atlikti pirminę pagrindinių ekonomikos indikatorių laiko eilučių analizę ir nustatyti jų nestebimas komponentes.

4. Atlikti ekonominių indikatorių modeliavimo metodų lyginamają analizę ir pasiūlyti modeliavimo metodika, leidžiančią tiksliau aprašyti tipines bei sudètingos prigimties ekonomikos indikatorių laiko eilutes.

5. Sudaryti modelio lygčių specifikacijas, ivertinti modelio lygčių parametrus ir ištirti sudarytų modelio lygčių ir prognozių tikslumą bei tvarumą.

6. Sukurti naujas programines priemones kompleksiniam šalies ekonomikos būsenos ir perspektyvos vertinimui, ekonominių scenarijų kūrimui, atskirų ekonomikos indikatorių pokyčių poveikio esamai šalies ekonomikos būsenai vertinimui.

\section{Tyrimų metodika}

Siekiant igyvendinti darbe numatytus tikslus ir išspręsti iškeltus uždavinius buvo nagrinèta ekonomikos, ūkio statistikos ir ekonometrijos teorija, analizuoti Lietuvoje ir kitose šalyse naudojami ekonominiai modeliai, atlikta ekonominiu indikatorių modeliavimo metodų lyginamoji analizè, tirti teoriniai modeliavimo metodai ir nustatytos jų praktinio panaudojimo galimybès. 


\section{Darbo mokslinis naujumas}

Darbo mokslinį naujumą rodo šie rezultatai:

1. Pasiūlyta nauja šalies ekonomikos būsenos ir perspektyvos vertinimo metodika, leidžianti analizuoti šalies ekonominių indikatorių tarpusavio ryšius ir jų tapatumą jų matuojamiems ekonominiams procesams, apskaičiuoti ekonominių indikatoriu trumpalaikes ir vidutinio ilgumo prognozes, atlikti vienalaikę ūkio analizę, analizuoti atskirų ypatumų ir sąlygų poveikị šalies ekonominei būklei ir perspektyvai.

2. Sukurtas kompleksinis šalies ekonominių indikatorių modelis, kuris leidžia stebèti, analizuoti ir prognozuoti ekonominius šalies procesus visumoje bei atskiras komponentes. Ivertintas modelio ir prognozių tvarumas. Ištirtas modelio lygčių parametrų stabilumas.

3. Irodyta, kad sudètingos elgsenos ekonominių indikatorių modeliavimui naudojant disertacijoje teikiamą adaptuotą SETAR modelį išsamiau atspindimi ekonominiai procesai, o tai galima nustatyti iš sumažejusių modelio lygčiu paklaidų.

4. Naudojant modeliuotas ir realias pagrindinių ekonomikos indikatorių sekas, atlikta nestebimų laiko eilučių komponenčių vertinimo metodų lyginamoji analizè.

5. Nustatyta, kad modeliuojant šalies ekonominių indikatorių laiko eilučių atskiras komponentes, pagal disertacijoje aprašytą metodika, pagerinamas modelio pagalba gautų prognozių tvarumas.

6. Sukurtos programinès priemonès, leidžiančios: kompleksiškai vertinti šalies ekonomikos būseną ir perspektyva, analizuoti šalies ūkio vedančiujuc ekonominių indikatorių pokyčius, ivvertinti modeliuojamų ekonominių indikatorių pokyčių poveikị šalies ekonomikai.

\section{Darbo rezultatų praktinė reikšmè}

Disertaciniame darbe teikiama šalies ekonomikos indikatorių dinamikos vertinimo metodika, kuri suteikia galimybę pilniau atspindèti esamus ekonominius procesus, o kartu gauti mažesnes modeliu bei prognozių paklaidas bei pagerinti atliekamos analizès bei rengiamų prognozių tikslumą bei tvarumą. Ši metodika yra tinkama ir sudètingos prigimties ekonominių indikatorių modeliavimui, kuriems iprasti laiko eilučiu modeliavimo metodai neduoda tinkamų rezultatų. 
Pasinaudojant darbe teikiama metodika, gauti disertacijoje aprašytų tyrimų rezultatai gali būti naudojami kompleksiniam šalies ekonominių indikatorių suderinamumo tikrinimui, patikimam vienalaikiam šalies vedančiujų ekonominių indikatorių vertinimui bei analizei, trumpalaikių ir vidutinio ilgumo prognozių rengimui, skirtingų ekonominių scenarijų kūrimui.

\section{Ginamieji teiginiai}

1. Dél Lietuvos ekonomikos ypatumų ir jų sąlygojamų apribojimų, esamų modelių aktualumo ir aprèpties stokos, kitų šalių bei Lietuvoje egzistuojančių ekonominių modelių taikymas, visuminei Lietuvos ūkio ekonominei analizei atlikti ir ekonominių indikatorių prognozei apskaičiuoti netikslingas arba gali būti taikoma tik fragmentiškai.

2. Modeliuojamų laiko eilučių struktūrinè analizè, išskiriant nestebimas laiko eilučiu komponentes leidžia tiksliau aprašyti vykstančius ekonominius procesus ir taip sumažinti modelių ir prognozių paklaidas.

3. Nestabilių sudètingos prigimties laiko eilučiu (su ivvairiais lūžiais, išsiskiriančiais stebejjimais, kintančia dispersija laike) modeliavimui darbe pasiūlytas adaptuotas SETAR metodas igalina sudaryti patikimus ekonominių indikatorių analizès bei prognozių vertinimo modelius.

4. Darbo autorès sukurtos originalios programinès priemonès leidžia atlikti kompleksinę pagrindinių šalies ekonominių indikatorių analizę, išmatuoti jų pokyčius priklausomai nuo sąlygojančiu pokyčių, sudaryti šalies ūkio ekonominius scenarijus, patikimai įvertinti šalies ekonomikos ir atskiru jos indikatorių perspektyvą.

\section{Darbo rezultatu aprobavimas}

Disertacijos tema paskelbti 9 moksliniai straipsniai: šeši - recenzuojamuose mokslo žurnaluose, trys - kituose recenzuojamuose mokslo leidiniuose. Disertacijos rezultatai buvo pristatyti dešimtyje Lietuvos ir tarptautinèse mokslinèse konferencijose:

- 5-oji Ernesto Galvanausko vardo tarptautinè mokslinè konferencija 2005 m. Šiauliuose, Lietuvoje;

- XLVI Lietuvos matematiku draugijos mokslinè konferencija $2005 \mathrm{~m}$. Vilniuje, Lietuvoje;

- Tarptautineje mokslineje konferencijoje „Conference on seasonality, seasonal adjustment and their implications for short-term analysis and 
forecasting” 2006 m. Liuksemburge, Liuksemburgo Didžiojoje Hercogysteje;

- XLVII Lietuvos matematikų draugijos mokslinè konferencija $2006 \mathrm{~m}$. Kaune, Lietuvoje;

- 7-oji Ernesto Galvanausko vardo tarptautinè mokslinè konferencija 2007 m. Šiauliuose, Lietuvoje;

- XLVIII Lietuvos matematikų draugijos mokslinè konferencija $2007 \mathrm{~m}$. Vilniuje, Lietuvoje;

- 12-oji tarptautinè mokslinè konferencija „,Mathematical Modelling and Analysis" 2007 m. Trakuose, Lietuvoje;

- Tarptautinè mokslinè konferencija „Nordic Conference on Mathematical Statistics" 2008 m. Vilniuje, Lietuvoje;

- XLIX Lietuvos matematikų draugijos mokslinè konferencija $2008 \mathrm{~m}$. Kaune, Lietuvoje;

- 13-oji tarptautinè mokslinè konferencija „Economics and Management" 2008 m. Kaune, Lietuvoje.

\section{Disertacijos struktūra}

Disertaciją sudaro ịvadas, trys skyriai, bendrosios išvados, literatūros šaltinių sąrašas, autorès publikacijų disertacijos tema sąrašas, aštuoni priedai, santrauka anglu kalba. Darbo apimtis - 130 puslapių, neskaitant prieduc, tekste yra 137 formulès, 44 paveikslai ir 8 lentelès. Rašant disertaciją buvo panaudoti 102 literatūros šaltiniai. 


\section{1}

\section{Ekonometrinio modeliavimo apžvalga ir tikslai}

Nors ekonometrinių modelių kūrimo ištakos siekia XVII amžių Davenant ir King darbuose, tačiau oficialia ekonometrijos, kaip atskiro mokslo atsiradimo data laikoma 1993 m., kai buvo isteigta Ekonometrijos draugija. Draugija ekonometrijos apibrèžime nurode, kad ekonometrija yra ekonomikos teorijos saryšis su statistika ir matematika, o jos tikslas - teoretinio ir empirinio kiekybinio požiūrio ekonomikos problemoms spręsti unifikavimas (Frisch, 1933).

Pagrindinès ekonometrinès funkcijos gana ženkliai prasiplètė nuo šio mokslo ikūrimo ir šiuo metu galima ịvardinti mažiausiai keturias pagrindines ekonometrijos funkcijas:

- Ekonometrija naudojama esamų ir apriorinių teorinių ekonomikos tiesų empiriniam patikrinimui;

- Ekonometrija gali būti naudojama ekonomikos teorijoje apibrèžtų bet praktikoje nestebimų kintamųų įvertinimui bei išmatavimui;

- Ekonometrijos mokslo metodais galima prognozuoti ekonominio kintamojo būsimas reikšmes.

- Ekonometrijos mokslas padeda nustatyti kintamujų tarpusavio ryšių charakteristikas. 


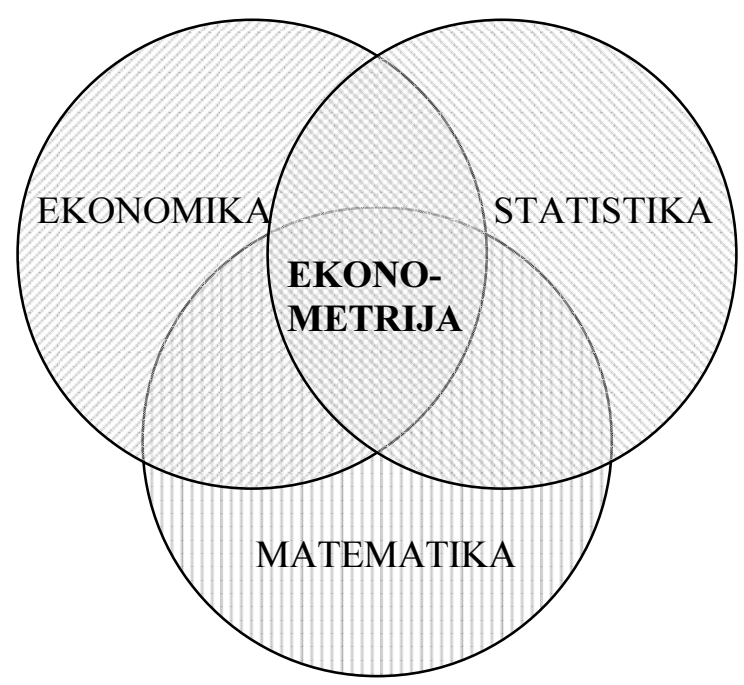

1.1 pav. Ekonometrijos mokslo sandara

Fig. 1.1. Structure of econometrics science

Ekonometrija suteikia galimybę atlikti realių ekonominių reiškinių kiekybinę analizę, pagrisstą šiuolaikine ekonomikos teorija ir naujausiais ekonometriniais duomenų analizès metodais. Sėkmingas ekonometrijos mokslo žinių taikymas priklauso ne tik nuo ekonometrijos metodų išmanymo, bet ir ekonomikoje vykstančių procesų supratimo bei turimo ekonominių duomenų paketo.

\subsection{Ekonometrinio modeliavimo tikslai}

Pirmieji ekonominiai modeliai atsirado XIX amžiaus pabaigoje, XX amžiaus pradžioje, kai žinomi to meto ekonomistai Walras, Klein, Keynes ir kt. bandė aprašyti ekonomiką vienalaikiai sprendžiama lygčių sistemomis. Remiantis šių iškilių ekonomistų idejomis, skirtingose šalyse buvo sukurtas ne vienas modelis.

Pagrindinis ekonominio modelio pranašumas išliko ir iki šių dienų vienalaike ekonomikos visumos analizè. Korektiškas ekonominis modelis atskleidžia ne tik ekonomikos rinkų tarpusavio ryšius bei priklausomybes, bet garantuoja prognozavimo vientisumą ir suderinamumą.

Ekonominių modelių kūrimui šiuo metu naudojamos ne tik balansinės, bet ir ekonometrinès lygtys. Kuriant modelius remiamasi ekonomikos, ekonometrijos ir matematinès statistikos mokslų žiniomis. Ekonometrinis 
modelis sujungia ekonominius reiškinius aiškinančias lygtis $i$ bendrą neprieštaraujančią sistemą.

Modelių reikšmè ir svarba pripažistama daugelyje pasaulio šalių bei atskirų institucijų, kur šiuo metu jau sukaupta ilgamete ekonominių modelių kūrimo ir taikymo patirtis. Pasaulio bankas nurodè, kad ekonominių modelių naudojimo sritys gali būti įvairios (A. Budraitytè, V. Kvedaras, 2000):

1. Ekonominio stabilumo palaikymo tyrimui.

2. Struktūrinių pasikeitimų padarinių vertinimui.

3. Ūkio raidos strategijos analizei.

4. Kiekybiniam svarstomų ir priimtų polinių sprendimų rezultatų vertinimui.

5. Vidaus ir išorès politikos tinkamumo tyrimams.

6. Skirtingų ekonominès politikos scenarijų poveikio ir sąnaudų vertinimui.

Dèl tokio plataus ekonominių modeliu panaudojimo galimybių, ekonometrinio modeliavimo poreikis tapo itin aktualiu kasdieniniu reiškiniu tiek sprendžiant ivairius mokslinius uždavinius, analizuojant esamą situaciją, tiek kuriant ịvairius politinius, socialinius ar ekonominius scenarijus, tiek ir norint ivertinti ivairiausių ekonominių indikatorių prognozes.

Kuriami ne tik nauji ekonominiai modeliai, bet ir praktikoje dažnai taikomi jau esami modeliai, adaptuojami kitų šalių modeliai. Todèl labai svarbu išanalizuoti ir jei įmanoma panaudoti sukauptą ekonominių modelių kūrimo bei taikymo patirti, palyginti modelio lygtis ir tapatybes, ivertinti taikytas modelio ekonomines bei matematines prielaidas. Šiame skyriuje apžvelgti ekonominio modeliavimo rezultatai Lietuvoje bei esami kitų šalių ekonometriniai bei pusiausvyros modeliai, analizuojamos jų taikymo galimybès Lietuvos ekonominių indikatorių modeliavimui.

\subsection{Trumpa ekonometrinio modeliavimo istorija}

Ekonominiai modeliai gali būti pagristi, iš dalies pagrịsti, ar visiškai nepagrịsti ekonomine teorija. Praktikoje, dažniausiai modeliai kuriami derinant keletą ekonominių teorijų ir ekspertinę patirti. Modeliai pritaikomi individualiems tikslams igyvendinti ir savitoms kiekvienos šalies ekonominėms priklausomybèms, vykdomai politikai (fiskalinei, monetarinei, socialinei) aprašyti. Todèl esami ekonominiai modeliai kiekvienai šaliai labai individualūs.

Ekonominius modelius dažniausiai kuria valstybinių, mokslo ir studijų institucijų darbuotojai ir analitikai. Norint, kad išliktų aktualumas esamai ekonominiai padèčiai, sukurti modeliai, modelių lygtys ir jų parametrai nuolat peržiūrimi ir atnaujinami. Dauguma kitų šalių modelių yra keleto dešimtmečių nuolatinio darbo rezultatas. 
Toliau pateiksime trumpa Anglijos banko ekonominio modelio, Austrijos makroekonominio modelio LIMA ir Nepalo makroekonometrinio modelio apžvalgą. Kadangi nemažai kitų šalių ir pasaulinių institucijų naudojami modeliai buvo analizuojami ir išsamiai aprašyti V. Avdejenkovos, V. Kvedaro, E. Mačiulaitytės darbuose, tai pasaulio banko modelio RMSM.X, kuris skirtas atskiru ūkio sektorių makroekonominiam subalansuotumo analizei bei prognozei, Švedijoje sukurto bendrosios pusiausvyros modelio KOSMOS, Korejos ekonominès pusiausvyros modeliu - BOK97 ir BOKAM97, kurie pagristi keinsistine pajamų-išlaidų metodologija, vidutinio dydžio ekonominis Suomijos modelio BOF (A. Willman ir kt., 1998, 2000), kuris turi daugiau nei 300 tapatybių, pagrisstų ekonomikos teorija ir dèl to kylanti lygčiu sistemos netiesiškuma, vidutinio laikotarpio makroekonometrinio modelio MODAG, naudojamo Norvegijos ekonomikos planavime, Nyderlandų banko daugiašalio modelio EUROMON (M. Demertzis ir kt., 2002), Centrinio ir Rytų Europos šalims skirto modelio LAM3 (W. Charemza ir kt., 2002), kuris skirtas ilgalaikei ekonominei analizei, šiame disertaciniame darbe išsamiai nebeaptarinèsime.

Nors Lietuvoje ekonominis modeliavimas vystomas jau senokai, tačiau dauguma ankstesnių tyrinejjimų Lietuvoje buvo skirti konkrečių sričių pagrindinių ekonominių indikatorių modeliavimui arba konkrečių uždavinių ir problemų sprendimui, kurie aprašomi ivvairiuose moksliniuose leidiniuose: Ž. Kalinauskas ir kt. (2000) darbe Lietuvos ekonomiką aprašo bendrosios pusiausvyros modeliu, kurio struktūra pagrissta $1997 \mathrm{~m}$. Lietuvos socialinès apskaitos matrica, R. Kuodis ir kt. $(2002,2005)$ analizavo pinigu politikos poveikio mechanizmus Lietuvoje, bei prognozavo valiutų krizes, A. Jakaitienè ir kt. (2003) prognozavo Lietuvos ekonomikos augimą taikant išankstinio ivertinimo metodą šalies realiojo bendrojo vidaus produkto pokyčiams trumpuoju laikotarpiu aprašyti, T. Ramanauskas ir kt. (2007) modeliavo namų ūkių vartojima, I. Vetlov ir kt. (2000, 2001, 2002, 2003, 2006) atliko Lietuvos infliacijos inercijos analizę, analizavo kainų kitimą ir tai ịtakojančius veiksnius, tyrè darbo rinkos lankstumą bei Baltijos šalių ekonomikos augimo apskaita, A. Proškutè (2012) ir kt. straipsnyje aprašè empirinị realaus verslo ciklo modelį, ivertintą 1995-2011 m. Lietuvos makroekonominiais duomenimis.

Norint, aktualizuoti ekonominius modelius, atsižvelgti į esminius pokyčius šalies ekonomikoje, pasinaudoti naujausiais statistiniais duomenimis, ekonometriniai modeliai turi būti periodiškai atnaujinami, tobulinamos modelio lygtys, pervertinami modelio lygčių parametrai. Daugumai toliau aprašomų darbų, tam, kad jie būtų aktualūs šiuo metu, būtinas atnaujinimas. Užsienio šalyse kurtus modelius sudètinga taikyti dèl šalių, kuriems buvo kurti ekonominiai modeliai ekonomikos ypatybių neatitikimo dabartinems 
ekonomikos salygoms ir specifikai. Toliau trumpai aprašysime Lietuvoje vykdytus projektus ir atliktus ekonominio modeliavimo darbus.

\subsubsection{Anglijos banko ekonominis modelis}

Anglijos banko ekonomini modeli (Bank of England, 1999) sudaro 20 pagrindinių ekonometrinių lygčių. Be pagrindinių lygčių modelyje naudojamos ivairios tapatybès, transformacijos ir susiejimo lygtys. Sudarytas modelis pakankamai gerai atspindi Jungtinès Karalystès ekonomika, nes modelio lygtyse naudojama 150 ketvirtinio dažnumo kintamujų.

Ekonomini modelį sudaro šeši struktūriniai blokai: pinigų, finansų ir turto, išeigos ir sąnaudų, darbo rinkos, kainų, fiskalinès politikos ir pajamų.

Modelio ilgalaikès pusiausvyros struktūrą apibendrina septyni sąryšiai:

1. Produkcija modeliuojama naudojant Cobb-Douglas funkcija, kurios pagrindiniai kintamieji yra darbas, kapitalas ir technologinis progresas:

$$
Q=\beta_{y}+\alpha T P+\alpha L+(1-\alpha) K .
$$

Čia $Q$ - produkcija, $K$ - kapitalas, $L$ - darbas ir $T P$ - technologinis progresas.

2. Darbo paklausa priklauso nuo produkcijos ir realaus darbo užmokesčio:

$$
Q-L=\beta_{l}+W-p^{d} .
$$

Čia $p^{d}-$ BVP defliatorius, $W$ - nominalus darbo užmokestis, $\beta_{l}-$ parametras, rodantis gamybos technologijos lygi.

3. Kapitalo paklausa ịvertinama pagal produkciją ir realią kapitalo kainą:

$$
Q-K=\beta_{k}+r c .
$$

Čia $r c$ - reali kapitalo kaina. $\beta_{k}$ - parametras, rodantis konkurencijos produktų rinkoje lygi.

4. Realūs darbo kaštai vertinami naudojant struktūrinius kintamuosius ir nedarbo lygi:

$$
W-p^{d}=\beta_{w}+Q-L+\theta_{1} Z^{s}-\theta_{2} U n .
$$

Čia $Z^{s}$ - struktūrinių kintamujų rinkinys, $U n$ - nedarbo lygis.

5. Bendroji paklausa apskaičiuojama sumuojant vartojimą, investicijas, atsargu pasikeitima, valdžios sektoriaus išlaidas ir grynaji eksportą (eksportą atemus importa). Kiekvienas bendrosios paklausos komponentas modeliuojamas atskirai. 
6. Pinigų paklausa priklauso nuo kainų lygio, pajamų ir turto, bei palūkanų normų.

$$
m^{d}-p^{d}=\beta_{m}+\gamma_{1} l_{t}+\gamma_{2}\left(a_{t}-p_{t}^{d}\right)+\gamma_{3}\left(i_{t}-i d_{t}\right) .
$$

Čia $\left(m^{d}-p^{d}\right)$ - pinigu paklausa, $l-$ pajamos, $\left(a-p^{d}\right)-\operatorname{turtas},(i-i d)-$ skirtumas tarp palūkanų normos ir indèlių palūkanų normos.

7. Kainų lygis priklauso nuo monetarinès politikos.

Be minètu modeliavimo metodu, Jungtinès Karalystès ekonominiame modelyje dar naudojami Philips kreivès ir atskirų ekonominių rodiklių modeliai, vektorinès autoregresijos (VAR) ir optimizavimo modeliavimo metodai.

\subsubsection{Austrijos makroekonominis modelis LIMA}

Austrijos makroekonomini modelį LIMA sudaro 78 lygtys, kuriose naudojami 78 metinio dažnumo endogeniniai kintamieji. Tik 21 iš 78 modelio lygčiu yra struktūrinès lygtys, su įvertintais koeficientais. Kitos modelio lygtys yra tapatybès. Todèl LIMA yra palyginus mažas makroekonominis modelis. Modelio parametrai atnaujinami vieną kartą metuose, kurie ịvertinami mažiausių kvadratų metodu.

Austrijos makroekonomini modelị sudaro septyni struktūriniai blokai: vidaus paklausos, importo ir eksporto, bendrosios gamybos, kainų, darbo rinkos, užsienio balanso, ir valstybès finansų.

LIMA yra tradicinis Keinistinis makroekonominių prognozių modelis, kuriame akcentuojama paklausa. Vidaus paklausa apskaičiuojama sumuojant privataus vartojimo, kuris skaidomas i ilgalaikiu, kitu prekių bei paslaugų vartojima, ir investiciju paklausos apimtis. Pagrindiniai aiškinamieji kintamieji vertinant investicijų paklausą yra bendrojo vidaus produkto pokyčiai ir praejusio laikotarpio investicijos, o privataus vartojimo komponentès modeliuojamos naudojant namų ūkių disponuojamas pajamas.

Importas modelyje yra endogeninis kintamasis, nes importo paklausa priklauso nuo vidaus paklausos, o eksportas naudojamas kaip egzogeninis kintamasis.

LIMA modelyje, sudaromos lygtys kiekvienos paklausos komponentès defliatorių vertinimui, t. y. modeliuojamos vartojimo, investicijų ir eksporto kainos. Importo kainos modelyje yra egzogeninis kintamasis. Egzogeniniu kintamuoju modelyje laikomas ir BVP komponentas - valdžios sektoriaus vartojimas. 


\subsubsection{Nepalo makroekonometrinis modelis}

Nepalo makroekonometrinis modelis yra vidutinio laikotarpio modelis. Modeli sudaro 37 lygtys, kuriose naudojami 59 metinio dažnumo kintamieji. Iš 37 lygčių 17 tapatybių. Todèl tai taip pat palyginus mažas makroekonometrinis modelis.

Nepalo makroekonometrinis modelis pagrịstas Keynes pajamų-išlaidų modeliu, kuriame bendraji vidaus produktą nulemia paklausa.

Makroekonometrini modelị sudaro penki struktūriniai blokai: galutinès paklausos, kainų, pinigų ir kreditų, valstybės finansų bei mokejjimo balanso.

Galutinès paklausos bloko pagrindinis ekonominis indikatorius yra realus bendrasis vidaus produktas. Kainų bloke modeliuojamas vartojimo kainų indeksas ir BVP defliatoriai, pinigu ir kreditu bloke P2 pinigų kiekis, valdžios sektoriaus bloke - nemokestinès pajamos (kiti šio sektoriaus endogeniniai kintamieji apibréžti tapatybèmis). Mokèjimų balanso bloke modeliuojamas prekių eksportas ir importas, užsienio skola bei oficialios kapitalo dotacijos.

\subsubsection{Ekonominis modeliavimas Lietuvoje}

Lietuvos makroekonometrinis modelis LITMOD. Vienas iš pirmuju makroekonometrinių modelių Lietuvoje buvo LITMOD (D. Celov ir kt., 2003). Pirmojoje LITMOD modelio versijoje pagrindinis dèmesys buvo skiriamas energijos suvartojimui. 2004 metais Ūkio ministerijos užsakymu, Ekonomikos institutas, kartu su Danijos Risoe nacionaline laboratorija pateiké atnaujintą ir išplèstą LITMOD2004 versiją bei pateikè pagrindinių ekonomikos augimo tempu prognozes iki 2020 metų. Kuriant modelį siekta apibūdinti trumpalaikę ir vidutinio laikotarpio Lietuvos ekonomikos plètrą ir struktūrą. Be to modelis turèjo padèti siekti vidinio ekonominès analizès nuoseklumo ir spręsti ekonominès plètros problemas. Pagrindinis projekto dèmesys buvo skirtas energijos suvartojimui. Tačiau tam, kad gauti patikimas energijos paklausos prognozes, autoriai turèjo gauti patikimas kitų sektorių ekonominès plètros prognozes.

LITMOD yra nedidelis, vidutinio laikotarpio, ketvirtinis paklausos modelis pagrịstas Keinistine makroekonomikos teorija. Visumine paklausa modelyje suskaidyta i privatu vartojima, investicijas, vyriausybini vartojima, eksportą ir importą. Modeliuoti ir atskiri pasiūlos elementai.

Svarbiausi modelio egzogeniniai kintamieji: gyventojų skaičius, ìvairūs mokesčiai, mokesčiu dydžiai, valdžios sektoriaus vartojimas, palūkanų norma, užsienio šalių kainos ir paklausa. Modelio endogeniniai rodikliai yra vartojimas ir paklausa, pajamos, valdžios sektoriaus deficitas, mokesčiai, darbo užmokestis, užimtumas, nedarbas ir darbo jèga, kainos, investicijos, importas, eksportas ir kiti rodikliai. 
Nagrinejjamiems rodikliams aprašyti LITMOD modelyje naudojamos lygtys su regresine ir autoregresine komponentemis:

$$
\begin{gathered}
\Delta \log (Y(t))=\beta \cdot \Delta \log \left(f\left(X_{1}(t), X_{2}(t)\right)\right)- \\
-\gamma\left(\log (Y(t-1))-\log \left(f\left(X_{1}(t-1), X_{2}(t-1)\right)\right)\right)+\varepsilon .
\end{gathered}
$$

Čia $Y$ - priklausomas kintamasis, $X_{1}, X_{2}$ - nepriklausomi kintamieji, $\alpha$ ir $\beta-$ vertinami parametrai.

Modelyje naudojamos ketvirtinès laiko eilutès nuo 1995 metų I ketvirčio iki 2002 metų II ketvirčio. Naudoti sektoriniai duomenys (bendroji produkcija, BVP, sąnaudos, investicijos ir darbas), valdžios sektoriaus finansai (išlaidos, pajamos, skola, biudžeto perteklius), gyventojai ir socialinè statistika (gyventojų skaičius, užimtujų skaičius, darbo jèga, nedarbo lygis), darbo užmokestis (vidutinis mènesinis darbo užmokestis privačiame ir valstybiniame sektoriuose), mokejjimų balansas (einamoji sąskaita, importas ir eksportas, tiesioginès užsienio investicijos), bendrosios pridètinès vertès komponentai (mokesčiai ir subsidijos gaminiams), pinigų valiutų ir finansų rinkos statistika (valiutos kursas, palūkanų normos).

Nors pirmoje LITMOD versijoje naudotiems rodikliams eliminuota sezoninè komponentè, vèliau, dèl lengvesnio gautų modelio duomenų palyginamumo su oficialiaja statistika, sezoninès komponentès eliminavimo atsisakyta. Sezoninei komponentei aprašyti autoriai naudojo tik fiktyviuosius kintamuosius.

LITMOD projekto direktorius Frits Møller Andersen ir profesorius Eduardas Vilkas ịvade pažymėjo, kad tam, kad modelis būtų naudingas, ekonominè ir ypač ekonometrinè modelio dalis reikalauja nuolatinès peržiūros, atnaujinimo ir naujų vertinimų. Nuo 2003 metų ivyko esminių pokyčių Lietuvoje, tačiau iki šių dienų nèra viešai prieinamos atnaujintos LITMOD modelio versijos.

Lietuvos bendrojo vidaus produkto modeliavimas. Bendrojo vidaus produkto, bendrosios pridètinès vertès (BPV) pirminių iverčių pagal EVRK sekcijas, atitinkančių naujausius Eurostato reikalavimus, skaičiavimo modeli 2003 metais daktaro disertacijoje „Bendrojo vidaus produkto modeliavimas“ pateikè Vitalija Avdejenkova (V. Avdejenkova, 2003). Autorè atliko išsamią kitų šalių makroekonominių modelių analizę ir nustatè, kad šiuose modeliuose taikomus BVP modeliavimo metodus, pirmajam Lietuvos BVP ịverčiui skaičiuoti naudoti netikslinga. Naudojant esamą standartinę programinę irangą, taip pat negalima operatyviai gauti pakankamai tikslius BVP iverčius. Savo darbe V. Avdejenkova taikydama ūkio statistikos, makroekonominės teorijos, indeksų teorijos, hipotezių tikrinimo, koreliacinès analizès, regresinès analizès, 
laiko eilučiu teorijos, kointegravimo analizès metodus, sukūrè BPV pirmojo iverčio skaičiavimo metodiką ir sudarè skaičiavimo algoritmus.

BPV įverčių skaičiavimui buvo taikomi 5 tipų ekonometriniai modeliai:

1. Modeliai, kuriuose dalyvauja regresinès, trendo, sezoninè ar autoregresinès komponentès ar jų derinys:

$$
\begin{aligned}
Y_{t}= & a_{0}+\sum_{k=1}^{K} \sum_{l=0,1,4} a_{k l} \cdot X_{k}(t-l)+b_{1} \cdot t+b_{2} \cdot \frac{1}{t}+ \\
& +\sum_{s=1}^{3} c_{s} \cdot S_{s}(t)+\sum_{j=1,4} d_{j} \cdot Y(t-j)+\varepsilon(t) .
\end{aligned}
$$

Čia $S_{1}(t), S_{2}(t), S_{3}(t)$ - sezono identifikavimo kintamasis:

$$
S_{i}(t)=\left\{\begin{array}{l}
0, \text { jei } t \neq i \text { ketvirtis } \\
1, \text { jei } t=i \text { ketvirtis }
\end{array}, i=1,2,3 .\right.
$$

2. Antro tipo modeliai skyrèsi nuo pirmojo tipo tik tuo, kad vertinant parametrus naudojamas apibendrintas mažiausių kvadratų metodas, kai liekanos yra autokoreliuotos.

3. Trečio tipo modeliuose nagrinèti transformuoti rodikliai: santykiniai rodiklių reikšmių pokyčiai per metus, atvirkštiniai rodikliai (priklausomas kintamasis, regresoriai arba visi kintamieji), pokyčiai per ketvirti bei jų logaritminès transformacijos.

4. Ketvirtojo tipo modelis - kointegravimo.

5. Penktojo tipo naudoti modeliai - liekanų. Šio tipo modeliai vertinami dviem etapas: eliminuojami ilgalaikiai trendai ir po to ieškoma prie ilgalaikio trendo pridedama trumpalaike priklausomybè.

Integracijos i Europos Sajungą pasekmių Lietuvos ūkiui makroekonometrinis modeliavimas. Virmantas Kvedaras, 2004 metais, daktaro disertacijoje „Integracijos i Europos Sajunga pasekmių Lietuvos ūkiui makroekonometrinis modeliavimas" darbo tikslu iškèlè sukurti integracijos i ES poveikio Lietuvos ūkio bendrajam vidaus produktui įvertinimo modeli bei nustatyti konkrečią integracijos itaką Lietuvos bendrajam vidaus produktui (V. Kvedaras, 2004). Sudarytas tikslinis integracijos pasekmių vertinimo makroekonometrinis modelis. Endogeniniais rodikliais pasirinkta bendroji produkcija, BVP, BVP defliatorius, darbo užmokestis, sąlyginis darbuotojų skaičius, visuminès privačios vartojimo išlaidos, valdžios išlaidos, visuminès investicijos ir importas. Darbo jèga, eksportas eksporto kainos, importo kainos, palūkanų normos buvo laikomi egzogeniniais kintamaisiais. 
Pirmiausia buvo formuojamas struktūinis modelis:

$$
\Gamma \Delta Y_{t}=H Z_{t-l}+F\left(t^{-}\right) \Delta Y_{t}+E\left(t^{-}\right) \Delta X_{t}+\operatorname{Det}_{t}+\varepsilon_{t} .
$$

Čia $Y_{t}$ - endogeninių kintamujjų vektorius, $X_{t}$ - egzogeninių kintamujų vektorius, $Z_{t}^{\prime}=\left(Y_{t}^{\prime}: X_{t}^{\prime}\right), \Gamma-$ normalizuota, vienalaikius ryšius tarp endogeninių kintamujų vektoriaus $Y_{t}$ apibrèžianti, parametrų matrica, narys $H Z_{t-1}$ apibrèžia stacionarias kointegruotų nestacionarių kintamujų tiesines transformacijas, $F(t)$ ir $E\left(t^{t}\right)-$ atitinkami véluojančių stacionarių endogeninių kintamujų bei stacionarių egzogeninių kintamujuc poveikị nusakantys polinomai, $t$ - vèlavimo operatorius, Det $_{t}$ - determinuota modelio dalis, galinti apimti trendo funkcija, fiktyvius sezoniškumo kintamuosius ir nuo laiko nepriklausančią konstanta, $\varepsilon_{t}-$ baltojo triukšmo procesas.

Po to tikrinamas modelio empirinis adekvatumas. Be to, buvo laikoma, kad struktūrinis modelis iš anksto apibrèžia potencialius kointegravimo vektorius ir jų skaičių. Naudojant kointegruotus kintamuosius, buvo sudarytas struktūrinis vektorinis paklaidų korekcijos modelis (SVECM).

\section{Lietuvos ekonomikos matematiniai modeliai ekonominiams procesams} prognozuoti. 2003 metais startavo projektas „Lietuvos ekonomikos matematiniai modeliai ekonominiams procesams prognozuoti“ (LEMM, 2003). Šio projekto vykdymo metu iškelti du pagrindiniai tikslai:

1. Sukurti taikomaji bendrosios pusiausvyros Lietuvos modeli socialinès apskaitos matricos (SAM) bazeje ir modeliuoti ivairius ekonomikos ir politikos poveikius (vidinius ir užsienio, nominalius ir realius), kurie ateityje galètų itakoti Lietuvos ekonomika;

2. Sukurti daugiasektorini makroekonometrini Lietuvos ekonomikos modeli, skirtą trumpalaikèms prognozèms.

Sukūrus modelius, planuota išbandyti juos sprendžiant mokesčiu politikos, darbo jègos migracijos procesu itakos, galimų vidinių investicijų itakos ekonomikos augimui, ES ekonominès politikos itakos Lietuvos ekonomikai, kitų Lietuvos integracijos i ES pasekmių itakos, socialinès politikos itakos, technologinès pažangos įtakos, bei kai kurių išorinių faktorių itakos, sprendimų, susijusių su energetikos sektoriumi, prièmimo, problemas.

Tiketasi, kad galutinis viso projekto rezultatas bus reguliaraus prognozavimo sistemos įdiegimas plačiam ekonominių ịvairių ekonomikos šakų kintamujų elgesiui prognozuoti, prognozavimo sistema igalins atlikti esamos ekonomikos būklès monitoringą.

Projekto rezultatai pateikti metinèse ataskaitose 2004, 2005 metais ir 2006 metų galutinejje ataskaitoje, tačiau apie jo taikymą ir atnaujinimus šiuo metu nepavyko rasti. 
Lietuvos verslo ciklų modeliai. Aurelija Proškutè, 2013 metais disertacijoje „Ekonominių ciklų dinamika Lietuvoje ir ją lemiantys struktūriniai veiksniai“" analizavo Lietuvos ekonominius ciklus bei juos lemiančias struktūrines priežastis. Buvo sudaryti du empiriniai verslo ciklų modeliai: dalinès bei bendrosios pusiausvyros, kuriais kiekybiškai vertinta struktūrinių šoku itaka Lietuvos bendrajam vidaus produktui (BVP), darbo produktyvumui, darbo pasiūlai bei visuminès paklausos komponentams. Darbe pristatyti abiejų modelių rezultatai Lietuvai, jie palyginti su kitų mažų atvirų augančių ekonomikų rezultatais.

Pirmiausia buvo sudarytas struktūrinès vektorinès autoregresijos modelis, kuris naudotas pagrindinių Lietuvos darbo produktyvumo ir dirbtų valandų, kuriuos itakoja technologiniai ir netechnologiniai šokai, verslo ciklų savybių nustatymui.

Antrasis ivvertintas modelis grindžiamas dinaminiu stochastiniu bendrosios pusiausvyros modeliu. Jis suteikia pilną informaciją apie verslo ciklus ir įvertina penkių šokų efektą agreguotai paklausai ir atskiriems jos komponentams: produkcijai, vartojimui, investicijoms ir darbo - produkcijos balanso santykiui.

Tyrimas parode, kad Lietuvos ekonomikos realiojo BVP dinamiką 1995$2011 \mathrm{~m}$. labiausiai įtakojo ilgalaikiai produktyvumo šokai. Antrasis pagal svarbą buvo pereinamasis produktyvumo šokas. Namų ūkių vartojimo pokyčius labiausiai lėmé preferencijų šokai ir jų paveikti tarplaikiniai vartojimo pasirinkimai. Didžiausias investicijų dinamikos veiksnys - palūkanų normų šokas. Nors valstybès išlaidų šokai neturejjo didelio ilgalaikio poveikio visuminès paklausos komponentu dinamikai, tačiau trumpuoju laikotarpiu ivertinta šių šoku i itaka prekybos balanso dalies bendrajame vidaus produkte dinamikai stipri. Prekybos balanso dalis BVP ilguoju laikotarpiu labiausiai priklause nuo preferencijų šokų. Taip pat ivertinta, kad technologiniai šokai neturi stipraus neigiamo poveikio darbo pasiūlai Lietuvoje.

\subsection{Pirmojo skyriaus išvados}

1. Daugelis pasaulio šalių bei pasaulinių institucijų naudoja ekonominius modelius skirtingiems tikslams bei uždaviniams spręsti (ekonominio stabilumo, struktūrinių pasikeitimų padarinių, ūkio raidos, kiekybiniam svarstomų ir priimtų sprendimų, vidaus iš išorès politikos tinkamumo ekonominiams tikslams pasiekti bei ekonomikos politikos scenarijų poveikio vertinimui bei tyrimui), todèl ju svarba ir aktualumas neabejotinas.

2. Pirmame disertacijos skyriuje pateikta Anglijos banko ekonominio modelio, Austrijos makroekonominio modelio LIMA, Nepalo 
makroekonometrinio modelio, ekonominio modeliavimo Lietuvoje apžvalga bei trumpai aptarti kiti ekonominiai modeliai, kurių gausa parodo, kad norint gauti adekvatų šalies ekonominiams procesams modelį, būtina atlikti išsamią šalies ypatumų, ekonominių ir matematinių prielaidų studijac atrinkti pagrindinių ekonomikos kintamujų rinkinį bei pasirinkti tinkamus modeliavimo metodus.

3. Atlikus užsienio šalių ekonominių modelių analizę, nustatyta, kad, dèl Lietuvos ūkio ypatumų ir jų sąlygojamų apribojimų, panaudoti kitų šalių kurtus modelius galima tik fragmentiškai.

4. Išanalizavus šalies ūkio modeliavimo patirti Lietuvoje, nustatyta, kad dauguma ankstesnių sukurtų modelių buvo skirti konkrečių sričių pagrindinių ekonominių indikatorių modeliavimui arba konkrečių uždavinių ir problemų sprendimui.

5. Nestabiliomis šalies ūkio raidos sąlygomis taikant ekonometrinius modelius būtina aktualizuoti periodiškai atnaujinant modelio lygtis, iš naujo ivvertinant jų parametrus, atsižvelgiant i pokyčius vidaus ekonomikoje ir jos aplinkoje. 


\section{2}

\section{Ekonometrijos anatomija. Ekonominių indikatorių modelio vertinimo metodai}

Patikima ir nuosekli šalies ūkio analizè leidžia turèti bendrą šalies ūkio raidos vaizdą, suteikia galimybę ívertinti priimamų politinių/socialinių sprendimų ekonominę naudą bei apskaičiuoti prognozes. Siam tikslui pirmiausia reikia nustatyti šalies ūkio sektorių svarbiausias charakteristikas, ivertinti analizuojamu ekonominių indikatorių tarpusavio ryšius, išanalizuoti jų modeliavimo galimybes, teorines prielaidas ir praktinio realizavimo būdus. Disertacijoje gvildenama problema - šalies ekonominių indikatorių modeliavimo teorinès ir praktinès galimybès, patikimų trumpalaikių prognozių apskaičiavimo būdai, ekonominių indikatorių laiko eilučių struktūros ir atskirų nestebimų komponenčių vertinimo galimybès ir modelio tikslumo aspektai.

Ivairūs ekonominiai, kalendoriniai, politiniai, demografiniai ar kiti pokyčiai veikia ekonomines laiko eilutes - atsiranda pastovūs ar atsitiktiniai svyravimai, ivairios išskirtys, struktūriniai lūžiai, reikšmingas dispersijos kitimas laike. Dèl šių priežasčių ekonominių indikatorių laiko eilutès tampa sudètingomis tiek savo prigimtimi, tiek jų vertinimo būdais. Tokias laiko eilutes pakankamai sudètinga aprašyti, taikant iprastus laiko eilučiu modeliavimo metodus. Dèl aukščiau paminètų priežasčių bei gana sudetingos Lietuvos ekonominès raidos, dauguma 
šalies ekonominių laiko eilučių reikalauja sudètingesnio ekonometrinio požiūrio. Šioms problemoms spręsti, darbe teikiama nauja šalies ekonominių indikatorių analizès ir modeliavimo metodologija - adaptuotas slenkstinis autoregresinis modelis (ASETAR), kai prieš modeliavimą atliekama pirminè laiko eilučių analize ir koregavimas bei laiko eilučių nestebimų komponenčių dažnuminė analizè.

Šiame skyriuje trumpai aprašyti darbe naudoti modeliavimo metodai, nusakytos priimtos prielaidos. Ypatingas dèmesys skirtas ekonominių laiko eilučių struktūrinei analizei, nes tolimesnejje darbo eigoje nustatyta, kad atskirų nestebimų laiko eilučių komponenčių vertinimas reikšmingai pagerina bendrą modelio paklaidą. Pristatytas disertacijoje teikiamo naujo sudètingos prigimties laiko eilučių modeliavimo metodo - ASETAR parametrų vertinimo algoritmas, aprašyta siūloma modelio lygčių sudarymo metodika.

Skyriaus tematika paskelbtos 2 autorès publikacijos (Bratčikovienè 2012, 2006) bei skaityti 3 pranešimai Lietuvos ir tarptautinèse mokslinèse konferencijose.

\subsection{Laiko eilučių analizè}

Laiko eilutès pagal savo charakteristikas (vidurki, dispersiją ir kovariacija) skirstomos i stacionarias ir nestacionarias. Stacionarioms laiko eilutems $y(t)$ aprašyti naudojami modeliai:

- $\quad p$-os eilès autoregresinis modelis $\operatorname{AR}(p)$ :

$$
y(t)=\alpha_{1} y(t-1)+\ldots+\alpha_{p} y(t-p)+\varepsilon(t),
$$

čia $\alpha_{1}, \ldots, \alpha_{p}$ - modelio parametrai, $\varepsilon_{t}-$ nepriklausomi standartiniai normaliai pasiskirstę atsitiktiniai dydžiai.

- $q$-os eilès slenkančio vidurkio modelis $\operatorname{MA}(q)$ :

$$
y(t)=\varepsilon(t)+\beta_{1} \varepsilon(t-1)+\ldots+\beta_{q} \varepsilon(t-q),
$$

čia $\beta_{1}, \ldots, \beta_{q}$ modelio parametrai, $\varepsilon(t)-$ nepriklausomi standartiniai normaliai pasiskirstę atsitiktiniai dydžiai.

- mišrus modelis $\operatorname{ARMA}(p, q)$ :

$$
y(t)=\alpha_{1} y(t-1)+\ldots+\alpha_{p} y(t-p)+\varepsilon(t)+\beta_{1} \varepsilon(t-1)+\ldots+\beta_{q} \varepsilon(t-q) .
$$

Ekonominių indikatorių laiko eilutès dažniausiai nèra stacionarios, bet jų skirtumų arba aukštesnès eilès skirtumų eilutè yra stacionari. Tokios laiko eilutès, naudojant skirtumines transformacijas, aprašomos $\operatorname{ARIMA}(p, d, q)$ modeliu. 
$\operatorname{ARIMA}(p, d, q)$ modelis užrašomas kaip $\operatorname{ARMA}(p, q)$ modelis laiko eilutès $d$-os eilès skirtumams $\Delta^{d} x(t)$ :

$$
\Delta^{d} y(t)=\alpha_{1} \Delta^{d} y(t-1)+\ldots+\alpha_{p} \Delta^{d} y(t-p)+\varepsilon(t)+\beta_{1} \varepsilon(t-1)+\ldots+\beta_{q} \varepsilon(t-q) .
$$

$\mathrm{Ne}$ visas laiko eilutes, naudojant skirtumines transformacijas, galima suvesti i stacionarias. Tokių laiko eilučių modeliavimui taikomi ịvairūs koregavimai, transformacijos ar sudetingesni modeliai. Dauguma Lietuvos ekonominių laiko eilučių yra gana sudètingos, todèl dažniausiai nepavyksta gauti tinkamų rezultatų, naudojant iprastus laiko eilučių analizès metodus. Tokios laiko eilutès reikalauja sudètingesnių ekonometrinių vertinimų.

\subsubsection{Laiko eilučių dekompozicija}

Norint gauti detalesnę informaciją apie nagrinejjamą ekonomini indikatorių, svarbu žinoti jo struktūrą - nustatyti nestebimas komponentes. Ekonometrinès ekonominių indikatorių laiko eilučių analizès rezultatai yra nestebimų laiko eilutès komponenčių (trendo, sezoninès, ciklo, atsitiktinės komponentès ir kt.) iverčiai.

Laiko eilutems aprašyti, priklausomai nuo jų prigimties, taikomi adityvūs, multiplikatyvūs ar pseudo-adityvūs modeliai. Toliau trumpai aprašysime šiame darbe naudotus laiko eilučių dekompozicijos modelius:

1. Adityvus modelis - paprasčiausias nestebimų laiko eilučių komponenčių modelis:

$$
y(t)=\sum_{i} U_{i}(t) .
$$

Čia $U_{i}(t)$ - nestebimos laiko eilučių komponentès.

2. Multiplikatyvus modelis dažniausiai taikomas laiko eilutems, kurių sezoninès komponentès dydis pastoviai auga arba mažeja laike. Tai būdinga daugumai makroekonominių laiko eilučių:

$$
y(t)=\prod_{i} U_{i}(t) .
$$

Multiplikatyvų modeli, pritaikius logaritmines transformacijas, galima nesudètingai suvesti $\mathfrak{i}$ adityvų modelį, todèl toliau darbe aprašysime tik adityvius modelius.

3. Laiko eilutėms, kurių reikšmès yra teigiamos, o kai kuriais atitinkamais laiko mementais reikšmès yra labai mažos arba lygios nuliui, taikomas ir pseudo-adityvus modelis: 


$$
y(t)=T(t) \times\left(\sum_{i}\left(\widetilde{U}_{i}(t)\right)-1\right)=T(t) \cdot(S(t)+I R(t)-1) .
$$

Šis modelis naudojamas X12-ARIMA metode. Išsamiau laiko eilučių modeliavimo metodai aprašyti 2.1.4 skyrelyje, o jų vertinimas, naudojant modeliuotas laiko eilutes, pateiktas 2.3.2 skyrelyje.

Laiko eilučių dekompozicijai dažniausiai naudojamos šios nestebimos laiko eilutès komponentès:

- trendas, kuris parodo ilgalaikę kitimo tendenciją (toliau žymèsime $T(t)$ ). Dažnai šią tendenciją galima aprašyti kokia nors neatsitiktine monotoniška funkcija. Naudojami parametriniai ir neparametriniai trendo įverčiai.

- sezoninè komponentè, kuri aprašo periodiškai pasikartojančius tam tikrais metų laikotarpiais analizuojamos eilutès reikšmių svyravimus (toliau žymėsime $S(t)$ ). I sezoninę komponentę įeina ir darbo dienų skaičiaus pasikeitimo bei švenčių įtakos įverčiai.

$$
\sum_{i=1}^{T} S(i)=0, S(i)=S(i+k \cdot T), i=1, \ldots, T, k=0, \ldots, \frac{N-1}{T} .
$$

- ciklo komponentè, kuri parodo ilgo laikotarpio, trunkančius ilgiau nei metai, nereguliarius svyravimus (toliau žymėsime $C(t)$ ).

- atsitiktinè komponentè, kuri nusako laiko eilutės atsitiktinius pokyčius (toliau žymėsime $I R(t)$ ). Dažniausiai ji aprašoma ARIMA modeliu.

\subsubsection{Laiko eilučių pirminè analizè ir koregavimas}

Pirminis laiko eilutès koregavimas atliekamas, norint tiksliau ivertinti nestebimas laiko eilutès komponentes. Pirmiausia ịvertinamos išsiskiriančios reikšmės, nustatoma kalendoriaus, specifinių poveikių (darbo dienų, Velykų, atostogų, istatymų pasikeitimo ir kt.) itaka laiko eilutès reikšmèms, po to jos eliminuojamos.

Pirminio koregavimo elementus galima suskirstyti $i$ tris grupes:

1. Išsiskiriantys stebẻjimai. Laiko eilutèse dèl įvairių ekonominių, politinių ar kitǔ priežasčiu gali atsirasti netikèti pasikeitimai, kuriuos sudètinga aprašyti ARIMA modeliu. Dažniausiai išskiriami trijų tipu išsiskiriantys stebèjimai (R. Kaiser, A. Maravall 2002):

- Adityvios išsiskiriančios reikšmès, momentiniai lygio pasikeitimai, veikiantys vieną laiko eilutès stebejjimą. Šiuos pokyčius gali 
sąlygoti streikai, staigus trumpalaikis oro sąlygu pasikeitimas ar kt. Adityvi išsiskirianti reikšmè užrašoma:

$$
D_{t}=\left\{\begin{array}{l}
0, \text { kai } t \neq t_{0} \\
1, \text { kai } t=t_{0}
\end{array} .\right.
$$

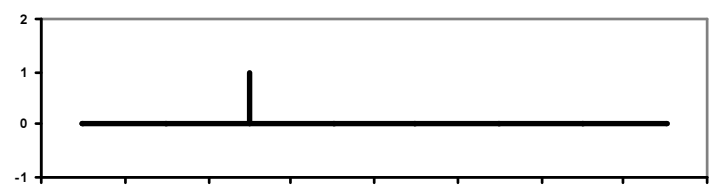

2.1 pav. Adityvios išsiskiriančios reikšmès schematinis vaizdavimas

Fig. 2.1. Schematic representation of additive outlier

- Lygio postūmiai, tai išskirtys, kai konkrečiu laiko momentu ženkliai pasikeičia laiko eilutès reikšmių vidurkis. Šis pokytis veikia visas laiko eilutès reikšmes nuo tam tikro momento. Pokyčiai gali atsirasti dèl pakitusio mokesčių tarifo, ekonominè krizès, struktūros pokyčio, teisès aktų pasikeitimo, tradicijų ar kitų priežasčių.

$$
D_{t}=\left\{\begin{array}{l}
0, \text { kai } t<t_{0} \\
1, \text { kai } t \geq t_{0}
\end{array}\right. \text {. }
$$

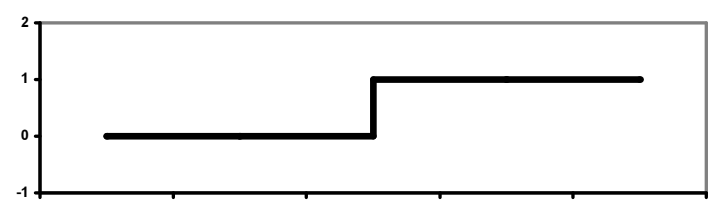

2.2 pav. Lygio postūmio schematinis vaizdavimas

Fig. 2.2. Schematic representation of level shift

- Praeinantys pokyčiai, tai išskirtys, panašios $\mathfrak{i}$ adityvias išsiskiriančias reikšmes, tačiau jų įtaka tęsiasi ilgiau nei vieną laikotarpi. Kaip ir lygio postūmio atveju, šie pokyčiai veikia ne vieną laiko eilutès reikšmę - pirmiausia ịvyksta staigus laiko eilutės reikšmių pokytis, o kitoms laiko eilutès reikšmėms šis poveikis 
mažèja eksponentiškai. Praeinantys pokyčiai gali atsirasti dèl ekonominès krizès, ilgesnị laikotarpi trunkančios orų permainos ar kt.

$$
D_{t}^{\left(t_{0}, t_{1}\right)}=\left\{\begin{array}{l}
-1, \text { kai } t \leq t_{0} \\
\left(t-t_{0}\right) /\left(t_{1}-t_{0}\right)-1, \text { kai } t_{0}<t<t_{1} . \\
0, \text { kai } t \geq t_{0}
\end{array}\right.
$$

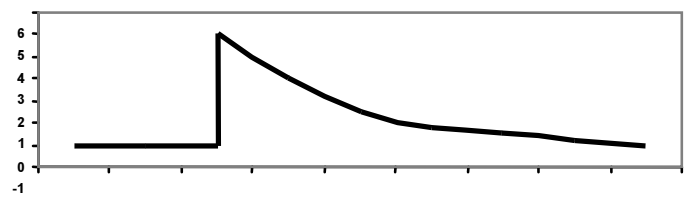

2.3 pav. Praeinančio pokyčio schematinis vaizdavimas Fig. 2.3. Schematic representation of transitory change

2. Kalendoriaus itaka. Ekonominèms laiko eilutèms būdingi ne tik atsitiktiniai, bet ir pasikartojantys svyravimai. Galimos pasikartojančių svyravimų priežastys - kalendoriaus, administraciniai, socialiniai, kultūriniai, religiniai faktoriai, t. y. laiko eilučių reikšmes itakoja skirtingas darbo dienų per laikotarpi skaičius, îvairios šventés ir atostogos.

2.1 lentelè. Regresiniai kintamieji, aprašantys kalendoriaus itaką

Table 2.1. Regression variables for calendar impact

\begin{tabular}{|c|c|}
\hline Regresorius & Kintamojo apibrèžimas \\
\hline $\begin{array}{lr}\text { Darbo } & \text { dienos } \\
\text { (mènesinio } & \text { ir } \\
\text { ketvirtinio dažnumo } \\
\text { laiko eilutems) }\end{array}$ & $\begin{array}{l}T_{1 t}=\text { pirmadieniu skaičius }- \text { sekmadieniu } \\
\text { skaičius } \\
\ldots, \\
T_{6 t}=\text { šeštadieniu skaičius }- \text { sekmadieniu } \\
\text { skaičius }\end{array}$ \\
\hline Mènesio ilgis & $\begin{array}{l}N_{t}-\bar{N}, \text { čia } N_{t}-t-\text { ojo mènesio dienų skaičius, } \\
\bar{N}=30,4375 \text { vidutinis mènesio dienų skaičius. }\end{array}$ \\
\hline Keliamieji metai & $\begin{array}{l}N_{t}-N_{t}^{*} \text {, čia } N_{t}^{*}=\left(N_{t}+N_{t-12}+N_{t-24}+N_{t-36}\right) / 4, \\
\text { ne vasario menesi kintamasis lygus } 0 .\end{array}$ \\
\hline
\end{tabular}


2.1 lentelès pabaiga

Table 2.1 ending

\begin{tabular}{|c|c|}
\hline Regresorius & Kintamojo apibrėžimas \\
\hline $\begin{array}{l}\text { Darbo dienu fondas } \\
\text { (stock) }\end{array}$ & $\begin{array}{l}T_{1, t}=\left\{\begin{array}{r}1 \widetilde{w}-\text { oji } t \text { mènesio diena pirmadienis, } \\
-1 \widetilde{w}-\text { oji } t \text { mėnesio diena sekmadienis, } \\
0, \text { kitais atvejais }\end{array}\right. \\
\ldots, \\
T_{6, t}=\left\{\begin{array}{cc}1 \widetilde{w}-\text { oji } & t \text { mènesio diena šeštadienis, } \\
-1 \widetilde{w}-\text { oji } & t \text { mènesio diena sekmadienis, } \\
0, \text { kitais atvejais }\end{array}\right.\end{array}$ \\
\hline Velykų šventė & $\begin{array}{l}E(w, t)=\frac{1}{w} \text {, dienų iki Velykų skaičius, } \\
\text { ne vasario, kovo, ir balandžio mènesiais (arba } \\
\text { pirma, antrą ketvirti) kintamasis lygus } 0 \text {. Vasario } \\
\text { ménesi nelygus } 0 \text {, tik kai } w>22 \text {. }\end{array}$ \\
\hline $\begin{array}{lr}\text { Tarptautinè } & \text { darbo } \\
\text { diena } & \text { (ménesinio } \\
\text { dažnumo } & \text { laiko } \\
\text { eilutėms) } & \end{array}$ & $\begin{array}{l}L(w, t)=\frac{1}{w} \text { čia } w-t \text {-ojo mènesio/ketvirčio } \\
\text { dienų iki Tarptautinès darbo dienos skaičius, } \\
\text { ne rugpjūčio ir rugsèjo mènesiais kintamasis } \\
\text { lygus } 0 .\end{array}$ \\
\hline
\end{tabular}

Kadangi darbo dienų skaičius kinta kiekvieną ketvirti/mėnesį, tai skirtingų laikotarpių rodiklių reikšmes sudètinga palyginti ne tik dèl sezoninių svyravimų bet ir dèl darbo dienų skaičiaus skirtumo. Be to, dauguma kalendorinių švenčių yra individualios kiekvienoje šalyje. Dèl skirtingo darbo dienų ar švenčių skaičiaus, net ir pagal identišką metodologija apskaičiuotų rodiklių reikšmès skirtingose šalyse tampa nepalyginamomis. Šios problemos sprendžiamos eliminuojant darbo dienų ir švenčių itaką tiriamo rodiklio reikšmẻms, dažniausiai modeliuojant regresijos metodu (R. Kaiser, A. Maravall 2002). Standartiniai regresiniai kintamieji, aprašantys kalendoriaus itaka, pateikti 2.1 lentelèje.

\subsubsection{Laiko eilučių spektrinè analizè}

Atlikus pirminę laiko eilutès analizę ir koregavima, norint nustatyti laiko eilutės nestebimas komponentes, koreguotos laiko eilutès reikšmėms taikoma dažnuminè spektrinè analizè.

Kai turime stacionarią laiko eilutę, tai ją galima išskaidyti ị begalinę svertinę periodinių ortogonalių komponentų sumą. Tuomet spektras apibrezžiamas: 


$$
\operatorname{Spectrum}_{y}(\omega)=\frac{1}{2 \pi} \sum_{j=-\infty}^{\infty} \gamma_{j} e^{-i \omega j}, \quad-\pi \leq \omega \leq \pi .
$$

Čia $i^{2}=-1, \omega-$ dažnis, matuojamas radianais, o $\gamma_{j}$ sekos $\{y(t)\}$ j-ojo vèlavimo autokovariacijos funkcija.

Tuomet egzistuoja procesas $\{z(\omega),-\pi \leq \omega \leq \pi\}$ (Brockwell ir Davis, 1991) toks, kad

$E\left[(z(\omega)-z(-\pi))(z(\omega)-z(-\pi))=F_{Y}[\omega]=\int_{-\pi}^{\omega} \operatorname{Spectrum}_{y}(\omega) d \omega\right],-\pi \leq \omega \leq \pi$

ir $y(t)=\int_{-\pi}^{\pi} e^{i \omega t} d z(\omega)$, t. y. $y(t)$ galima išskaidyti į begalinę svertinę ortogonolių svyravimų, kurių dažnis $\omega$, sumą.

Integruotų laiko eilučių dažnuminei analizei atlikti naudojamas pseudospektras:

$$
S_{y}(\omega)=\frac{\sigma_{\varepsilon}^{2}}{2 \pi\left|1-e^{-i \omega}\right|^{2}}, \omega \neq 0
$$

Spektro funkcijos pikai parodo esamas laiko eilutės komponentes. Pikas, kai $\omega=0$, siejamas su trendo komponente. Pikai esantys intervale $\left[0+\varepsilon_{1} ; \frac{\pi}{2}-\varepsilon_{2}\right]$, kai $\varepsilon_{1}, \varepsilon_{2}>0$ ir $\varepsilon_{1}<\frac{\pi}{2}-\varepsilon_{2}$ parodo, kad tiriamoje laiko eiluteje yra svyravimų, kurių periodas ilgesnis nei metai, t.y. egzistuoja ciklo komponentè. Pikas, kai $\omega=\frac{\pi}{2}$ rodo, kad laiko eilutejje egzistuoja svyravimai besikartojantys vieną kartą kiekvienais metais, t.y. laiko eilutejje reikšminga sezoninè komponentè. Jeigu egzistuoja pikai intervale $\left(\frac{\pi}{2} ; \pi\right)$, tai parodo, kad laiko eiluteje egzistuoja svyravimai, kurių periodas yra trumpesnis nei metai. Pikas kai $\omega=\pi$, parodo, kad laiko eiluteje yra sezoniškumų kurie kartojasi du kartus per metus. 


\subsubsection{Laiko eilučių modeliavimo metodai}

Egzistuoja parametriniai ir neparametriniai laiko eilučių nestebimų komponenčių modeliavimo metodai, kurie naudoja skirtingus algoritmus ir principus. Toliau pateikiame trumpą šių metodų aprašymą.

Bendrą parametrini laiko eilutès modeli galime užrašyti:

$$
y(t)=\beta R^{\prime}(t)+\eta^{\prime} \text { Cal }(t)+\sum_{j=1}^{k} \alpha_{j} \lambda_{j} \operatorname{Ind}\left(t_{j}\right)+\sum_{i=1}^{l} U_{i}(t) .
$$

Čia $\beta=\left(\beta_{1}, \beta_{2}, \ldots, \beta_{n}\right)^{\prime} \quad-\quad$ regresijos parametrų vektorius, $R^{\prime}(t)=\left(r_{1}(t), r_{2}(t), \ldots, r_{n}(t)\right)$ regresoriniai kintamieji, Cal $(t)$ - matrica, kurios stulpelius sudaro kalendoriaus (darbo dienų, Velykų efekto, keliamujų metų ir kt.,) kintamieji, o $\eta^{\prime}$ atitinkamai kalendoriaus kintamujų koeficientų vektorius, $\operatorname{Ind}\left(t_{j}\right)$ galimų išsiskiriančiu stebejjimų periodu $t_{j}$ indikatorius, $\lambda_{j}-j$-taji išsiskirianti stebejjimą nusakantis kintamasis, $\alpha_{j}-$ vertinami atitinkami parametrai, $U_{i}(t)$ nestebimos (trendo, sezoninè ir atsitiktinè) laiko eilutès komponentès.

Parametriniuose laiko eilučių nestebimų komponenčių modeliavimo metoduose, trendo komponentė aprašoma tam tikra determinuota funkcija (pvz. tiesine, logaritmine, eksponentine, polinomine ir kt.), kurios parametrai ivertinami mažiausių kvadratų arba maksimalaus tikètinumo metodais.

Sezoninè komponentè laiko momentu $t$ apibrèžiama:

$$
S(t)=\sum_{i=1}^{s-1} \alpha_{i} D_{i}(t)
$$

kai

$$
D_{i t}=\left\{\begin{array}{l}
1 \text { kai } t=i+k s \\
0 \text { kai } t \neq i+k s
\end{array} .\right.
$$

Čia $\alpha_{i}$ - vertinami parametrai, sąlyginis laikas $t=1,2, \ldots, N, i=1,2, \ldots, s$ $1, k=0,1, \ldots$, o $s$ - laiko eilutès periodiškumas.

Toks sezoninès komponentès apibrèžimas tenkina fiksuotos sezoninès komponentès reikalavimą, kad metų sezoninès komponentès reikšmių suma lygi nuliui: 


$$
\sum_{i=1}^{s} S_{i}=0
$$

Nežinomų sezoninès komponentės parametrų vertinimui taip pat naudojami mažiausių kvadratų arba maksimalaus tikètinumo metodai. Toliau trumpai aprašysime šiuos metodus.

\section{Mažiausių kvadratų metodas}

Tegul galioja modelis $\mathbf{U}=\theta^{T} \mathbf{X}+\boldsymbol{E}$, čia $\mathbf{U}=\left(U_{1}, \ldots, U_{n}\right)^{T}-$ nestebimų laiko eilutès komponenčių reikšmių vektorius, $\theta=\left(\theta_{1}, \ldots, \theta_{n}\right)^{T}-$ nežinomų parametrų vektorius, $\mathbf{X}=\left(X_{1}, X_{2}, \ldots, X_{n}\right)$ - daugiamačių determinuotų dydžių $X_{1}, X_{2}, \ldots, X_{n}$ matrica, $\boldsymbol{\varepsilon}=\left(\varepsilon_{1}, \ldots, \varepsilon_{n}\right)^{T}$ - modelio liekanų vektorius.

Mažiausių kvadratų metodo esmè yra rasti tokius nežinomu parametrų $\theta$ iverčius $\hat{\theta}$, kurie minimizuotuc modelio paklaidas, t.y. $\hat{\theta}=\underset{\theta}{\arg \min } S(\theta)=\underset{\theta}{\arg \min } \sum_{t=1}^{n}(U(t)-\hat{U}(t))^{2}$. Matricinejje formoje $S(\theta)=\left(\mathbf{U}-\theta^{T} \mathbf{X}\right)\left(\mathbf{U}-\theta^{T} \mathbf{X}\right)^{T}$. Funkcijos $S(\theta)$ minimumo tašką surandame apskaičiavus išvestinę $\frac{1}{2} S^{\prime}(\theta)=-\mathbf{X} \mathbf{U}^{T}+\mathbf{X} \mathbf{X}^{T} \theta$ ir prilyginus ją 0 . Gauname $\mathbf{X X}^{T} \boldsymbol{\theta}=\mathbf{X} \mathbf{U}^{T}$. Jei matrica $\mathbf{B}=\mathbf{X} \mathbf{X}^{T}$ yra neišsigimusi, tai egzistuoja vienintelis sprendinys $\hat{\theta}=\mathbf{B}^{-1} \mathbf{X} \mathbf{Y}^{T}$, kuris vadinamas mažiausių kvadratų metodo įverčiu.

\section{Maksimalaus tikètinumo metodas}

Maksimalaus tikètinumo metodo įverčiai yra vieni iš tiksliausių, bet dažnai sunkiai įvertinami. Šis metodas gali būti taikomas kai žinomas skirstinys, pagal kuri pasiskirstęs nagrinejjamas atsitiktinis dydis.

Tegul nagrinėjamo atsitiktinio dydžio tankio funkcija yra $f(x)$, $f \in\left\{f_{\theta}, \theta \in \Theta\right\}$ tai tikètinumo funkcija apibrèžiama $L(\theta)=\prod_{j=1}^{n} f_{\theta}\left(X_{j}\right)$.

Nežinomų parametrų $\hat{\theta}$ maksimalaus tikètinumo ịvertis yra funkcijos $L(\theta)$ maksimumo taškas, t.y. $\hat{\theta}=\underset{\theta \in \Theta}{\arg \max } L(\theta)$. Kad ịvertinti nežinomus parametrus, dažniausiai funkcija $L(\theta) \quad$ logaritmuojama $\quad l(\theta)=\ln L(\theta) . \quad$ Kadangi 
$\theta=\left(\theta_{1}, \ldots, \theta_{n}\right)^{T}$ turime $n$ nežinomų parametrų, tai toliau apskaičiuojamos dalinès $l(\theta)$ išvestinès pagal $\theta_{1}, \ldots, \theta_{n}$ ir prilyginamos 0 . Gautas rezultatas laikomas maksimalaus tikètinumo metodo ivverčiu.

Kai turime Gauso skirstini, maksimalaus tikètinumo metodo ivertis sutampa mažiausių kvadratų metodo įverčiu, t. y. $\hat{\theta}=\mathbf{B}^{-1} \mathbf{X} \mathbf{Y}^{T}$.

Neparametrinis laiko eilučių nestebimų komponenčių vertinimo metodas X12-ARIMA sukurtas X-11 (J. Shiskin, A. H. Yong ir J. C. Musgrave, 1967), X11-ARIMA ir X-11-ARIMA/88 (E. B. Dagum, 1988) metodu pagrindu.

X-12-ARIMA metodo nestebimų komponenčių vertinimo procedūra pavaizduota 2.4 paveiksle.

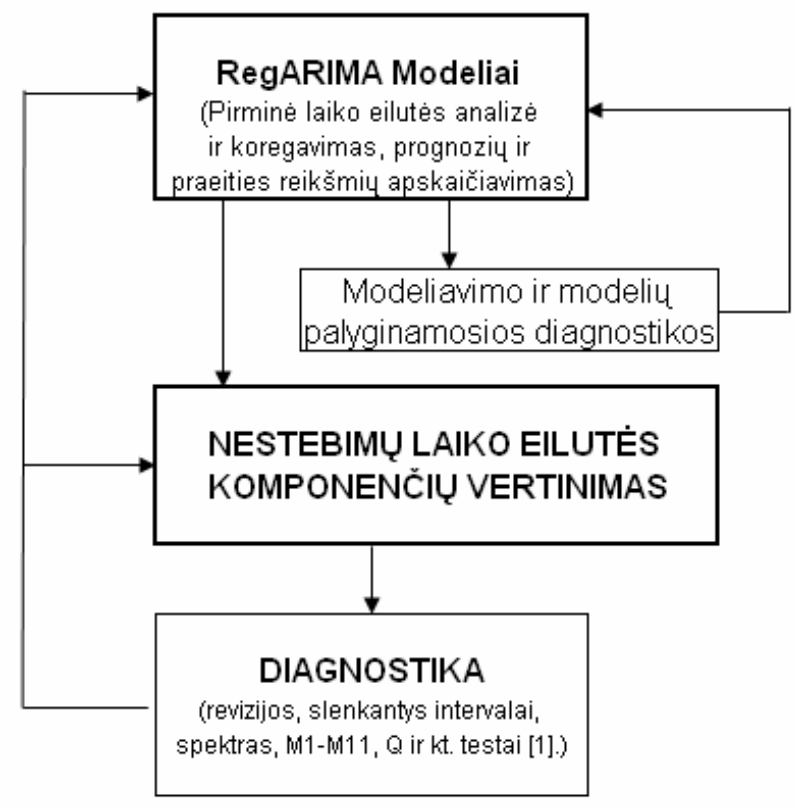

2.4 pav. X-12-ARIMA metodo laiko eilučių nestebimų komponenčių vertinimo procedūra

Fig. 2.4. Unobserved time series components estimation in X-12-ARIMA

Laiko eilučiu nestebimų komponenčių vertinimui X-12-ARIMA metodu, daroma prielaida, kad laiko eilutę sudaro trys nestebimos komponentès: trendas, 
sezonine ir atsitiktinè komponentès. Vertinimas atliekamas trimis etapais: pirminè dekompozicija, sezoninès komponentès ir laiko eilutès, eliminavus sezoninę komponentę ívertinimas, galutinis Hendersono trendo ir galutinès atsitiktinès komponentès nustatymas. Toliau pateikiama nestebimų laiko eilutès komponenčių vertinimo procedūra mènesinio periodiškumo laiko eilutėm.

1. Jei $Y_{t}$ mènesinio periodiškumo laiko eilutè, be išsiskiriančių reikšmių, tai pirmame etape apskaičiuojamas pirminis trendas:

$$
T_{1}(t)=\frac{1}{24} Y(t-6)+\frac{1}{12} Y(t-5)+\ldots+\frac{1}{12} Y(t)+\ldots+\frac{1}{12} Y(t+5)+\frac{1}{24} Y(t+6) .
$$

Naudojant svertinị slenkantị vidurkị apskaičiuojama pradinè preliminari sezoninè komponente:

$$
\begin{aligned}
& \hat{S}_{1}(t)=\frac{1}{9} S I_{1}(t-24)+\frac{2}{9} S I_{1}(t-12)+ \\
& +\frac{3}{9} S I_{1}(t)+\frac{2}{9} S I_{1}(t+12)+\frac{1}{9} S I_{1}(t+24) .
\end{aligned}
$$

- Multiplikatyvaus ir pseudo-adityvaus modelio atveju

$$
S I_{1}(t)=\frac{Y(t)}{T_{1}(t)},
$$

- adityvaus modelio atveju

$$
S I_{1}(t)=Y(t)-T_{1}(t) .
$$

Preliminarus sezoninis faktorius apskaičiuojamas:

- multiplikatyvaus ir pseudo-adityvaus modelio atveju

$$
S_{1}(t)=\frac{\hat{S}_{1}(t)}{\frac{1}{24} \hat{S}_{1}(t-6)+\frac{1}{12} \hat{S}_{1}(t-5)+\ldots+\frac{1}{12} \hat{S}_{1}(t+5)+\frac{1}{24} \hat{S}_{1}(t+6)},
$$

- adityvaus modelio atveju

$$
S_{1}(t)=\hat{S}_{1}(t)-\left(\frac{\hat{S}_{1}(t-6)}{24}+\frac{\hat{S}_{1}(t-5)}{12}+\ldots+\frac{\hat{S}_{1}(t+5)}{12} 6+\frac{\hat{S}_{1}(t+6)}{24}\right)
$$

Pradinè laiko eilutè, eliminavus sezoną apskaičiuojama:

- multiplikatyvaus modelio atveju

$$
A_{1}(t)=\frac{Y(t)}{S_{1}(t)}
$$


- adityvaus modelio atveju

$$
A_{1}(t)=Y(t)-S_{1}(t),
$$

- pseudo-adityvaus modelio atveju

$$
A_{1}(t)=Y(t)-T_{1}(t)\left(S_{1}(t)-1\right) .
$$

2. Antrajame etape ivertinama sezoninè komponentė ir gaunama laiko eilute eliminavus sezoninę komponentę. Tam nustatomi Hendersono svoriai $h_{j}^{(2 H+1)},-H \leq j \leq H,\left(h_{j}=h_{-j}\right)$

$$
h_{j}^{(2 H+1)}=\frac{315\left[(n-1)^{2}-j^{2} \llbracket n^{2}-j^{2}\right]\left[(n+1)^{2}-j^{2}\left[3 n^{2}-16-11 j^{2}\right]\right.}{8 n\left(n^{2}-1\right)\left(4 n^{2}-1\right)\left(4 n^{2}-9\right)\left(4 n^{2}-25\right)},
$$

bei tenkinantys savybes $\sum_{j=-p}^{p} h_{j}=1, \sum_{j=-p}^{p} j h_{j}=0, \sum_{j=-p}^{p} j^{2} h_{j}=0$.

Apskaičiuojamas tarpinis trendas:

$$
T_{2}(t)=\sum_{j=-H}^{H} h_{j}^{(2 H+1)} A_{1}(t+j) .
$$

Naudojant svertini slenkanti vidurki, ivvertinama preliminari sezoninè komponentè

$$
\begin{aligned}
& \hat{S}_{2}(t)=\frac{1}{15} S I_{2}(t-36)+\frac{2}{15} S I_{2}(t-24)+\frac{3}{15} S I_{2}(t-12)+\frac{3}{15} S I_{2}(t) \\
& +\frac{3}{15} S I_{2}(t+12)+\frac{2}{15} S I_{2}(t+24)+\frac{1}{15} S I_{2}(t+36) .
\end{aligned}
$$

- multiplikatyvaus ir pseudo-adityvaus modelio atveju

$$
S I_{2}(t)=\frac{Y(t)}{T_{2}(t)},
$$

- adityvaus modelio atveju

$$
S I_{2}(t)=Y(t)-T_{2}(t) .
$$

Apskaičiuojama galutinè sezoninè komponentè

- multiplikatyviam ar pseudo-adityviam modeliui

$$
S_{2}(t)=\frac{\hat{S}_{2}(t)}{\frac{1}{24} \hat{S}_{2}(t-6)+\frac{1}{12} \hat{S}_{2}(t-5)+\ldots+\frac{1}{12} \hat{S}_{2}(t+5)+\frac{1}{24} \hat{S}_{2}(t+6)},
$$


o adityviam modeliui

$$
S_{2}(t)=\hat{S}_{2}(t)-\left(\frac{\hat{S}_{2}(t-6)}{24}+\frac{\hat{S}_{2}(t-5)}{12}+\ldots+\frac{\hat{S}_{2}(t+5)}{12}+\frac{\hat{S}_{2}(t+6)}{24}\right) .
$$

Ivertinama laiko eilute, kuriai eliminuota sezoninè komponenté:

- multiplikatyvaus modelio atveju

$$
A_{2}(t)=\frac{Y(t)}{S_{2}(t)},
$$

- adityvaus modelio atveju

$$
A_{2}(t)=Y(t)-S_{2}(t),
$$

- pseudo-adityvaus modelio atveju

$$
A_{2}(t)=Y(t)-T_{2}(t)\left(S_{2}(t)-1\right) .
$$

3. Trečiajame etape įvertinamas galutinis Hendersono trendas ir galutinè atsitiktinè komponentè.

Galutinio trendo iqvertinimas atliekamas pagal

$$
T_{3}(t)=\sum_{j=-H}^{H} h_{j}^{2 H+1} A_{2}(t+j) .
$$

Galutinè atsitiktinė komponentė apskaičiuojama:

- multiplikatyvaus ir pseudo-adityvaus modelio atveju

$$
I R_{3}(t)=\frac{A_{2}(t)}{T_{3}(t)},
$$

- adityvaus modelio atveju

$$
I R_{3}(t)=A_{2}(t)-T_{3}(t) .
$$

\subsubsection{Laiko eilučių nestebimų komponenčių vertinimo diagnostika}

Ivertinus laiko eilutès nestebimas komponentes, tikslinga patikrinti jų kokybę. Tai atliekama apskaičiuojant diagnostines statistikas, tikrinant liekanų autokoreliacija, nepriklausomumą, liekanų pasiskirstymą pagal normaluji dėsni. Modeliuojant X-12-ARIMA metodu vertinamos M1, M3-M11 kokybès statistikos. Šios statistikos igyja reikšmes nuo 0 iki 3. Sudarytų modelių kokybẻ tinkama, jei M1, M3-M11 statistikų igytos reikšmès yra mažesnès už 1. 
- M1 statistika matuoja atsitiktinès komponentès įtaką laiko eilutei. Jei atsitiktinė komponentė reikšmingai įtakoja laiko eilutès reikšmes, tai sudètinga pakankamai tiksliai išskirti nestebimas laiko eilutès komponentes (D. Ladiray, B. Quenneville, 2001):

$$
M 1=10 * \frac{\bar{I}_{3}^{2}}{\bar{O}_{3}^{\prime 2}}
$$

čia $\quad \bar{O}_{l}^{\prime 2}=\bar{I}_{l}^{2}+\overline{T C}_{l}^{2}+\bar{S}_{l}^{2}, \quad$ o $\quad \bar{I}_{l}^{2}=\sum_{t=2}^{N}\left(I R_{t}-I R_{t-l}\right)^{2} /(N-1)$, $\overline{T C}_{l}^{2}=\sum_{t=2}^{N}\left(T C_{t}-T C_{t-l}\right)^{2} /(N-1), \bar{S}_{l}^{2}=\sum_{t=2}^{N}\left(S_{t}-S_{t-l}\right)^{2} /(N-1)$.

Čia $I R$ - atsitiktinè komponentè, $T C$ - trendo-ciklo komponente, $S$ sezoninè komponentè.

- M3 statistika matuoja atsitiktinès ir trendo komponenčių sąryši. Mènesinio dažnumo laiko eilutėms ši statistika apskaičiuojama pagal:

$$
M 3=\frac{1}{2} \times\left(\frac{\bar{I}}{\overline{T C}}-1\right),
$$

ketvirtinio dažnumo laiko eilutèms

$$
M 3=\frac{1}{0,67} \times\left(\frac{\bar{I}}{\overline{T C}}-0,33\right) .
$$

- M4 statistika vertina ar liekamasis narys yra atsitiktinis. Tam naudojama $A D R$ statistika, kuri parodo vidutini nuosekliai einančių mènesių skaičių, kurių pokyčiai yra to paties ženklo (augimas arba kritimas) (D. Ladiray, B. Quenneville, 2001).

$$
M 4=\frac{\left|\frac{N-1}{A D R}-\frac{2(N-1)}{3}\right|}{2,577 \times \sqrt{\frac{16 N-29}{90}}} .
$$

- M5 statistika vertina atitinkamų atsitiktinès komponentès ir trendociklo komponentès pokyčiu dydi. Apskaičiuojami $\frac{\bar{I}_{k}}{\overline{T C}_{k}}$ santykiai, čia $k$ yra vèlavimo parametras ( $k$ kinta nuo 1 iki 12 ménesinio dažnumo laiko 
eilutėms, arba nuo 1 iki 4 ketvirtinio dažnumo laiko eilutėms). Surandamas toks $k, \quad$ kad $\quad \frac{\bar{I}_{k}}{\overline{T C}_{k}} \leq 1$, su bet kuriuo $j \geq k . \quad$ Kai

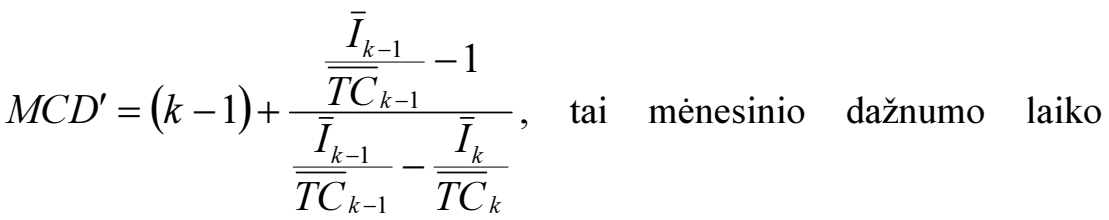
eilutèms:

$$
M 5=\frac{M C D^{\prime}-0,5}{5},
$$

ketvirtinio dažnumo laiko eilutėms:

$$
M 5=\frac{Q C D^{\prime}-0,17}{1,67},
$$

čia $Q C D^{\prime}$ apskaičiuojamas ketvirtinio dažnumo laiko eilutèms analogiškai kaip ir $M C D^{\prime}$ mènesinio dažnumo.

- M6 statistika vertina ar imanoma kokybiškai atskirti atsitiktinę komponentę nuo sezoninès.

$$
M 6=\frac{1}{2,5} \times\left|\frac{\bar{I}}{\bar{S}}-4\right| .
$$

- $M 7$ statistika naudojama, nustatyti ar sezoninę komponentę galima vertinti naudojant X-12-ARIMA metodą.

$$
M 7=\sqrt{\frac{1}{2}\left(\frac{7}{F_{S}}+\frac{3 F_{M}}{F_{S}}\right)} .
$$

Čia $\quad F_{S}=\frac{S_{A}^{2} /(k-1)}{S_{R}^{2} /(n-k)}, \quad F_{M}=\frac{S_{B}^{2} /(N-1)}{S_{R}^{2} /(N-1)(k-1)}$,

$S_{A}^{2}=N \sum_{j=1}^{k}\left(\sum_{i=1}^{N} \frac{X_{i j}}{N}-\sum_{j=1}^{k} \sum_{i=1}^{N} \frac{X_{i j}}{k N}\right)^{2}, S_{B}^{2}=k \sum_{i=1}^{N}\left(\sum_{j=1}^{k} \frac{X_{i j}}{k}-\sum_{j=1}^{k} \sum_{i=1}^{N} \frac{X_{i j}}{k N}\right)^{2}$

ir $S_{R}^{2}=\sum_{i=1}^{N} \sum_{j=1}^{k}\left(X_{i j}-\sum_{j=1}^{k} \frac{X_{i j}}{k}-\sum_{i=1}^{N} \frac{X_{i j}}{N}+\sum_{j=1}^{k} \sum_{i=1}^{N} \frac{X_{i j}}{k N}\right)^{2}$. 
- $\quad M 8$ statistika matuoja sezoninès komponentès svyravimų dydị.

$$
M 8=100 \times|\Delta \bar{S}| \times \frac{1}{10},
$$

$$
\text { čia }|\Delta \bar{S}|=\frac{1}{\sum_{j=1}^{k}\left(n_{j}-1\right)} \sum_{j=1}^{k} \sum_{i=2}^{n_{j}}\left|S_{i, j}-S_{i-1, j}\right| \text {. }
$$

- $M 9$ statistika matuoja sezoninès komponentès svyravimų tendencijas. Jei sezonineje komponenteje yra tik atsitiktiniai svyravimai, tai $M 9$ statistikos reikšmè bus artima 0 .

$$
M 9=\frac{10}{\sum_{j=1}^{k}\left(n_{j}-1\right)} \sum_{j=1}^{k}\left|S_{n_{j}, j}-S_{1, j}\right| .
$$

- $\quad$ M10 statistika sutampa su M8 statistika, jei matuojame paskutinių trijų metų svyravimus.

$$
M 10=100 \times|\Delta \bar{S}|_{R} \times \frac{1}{10},
$$

čia $|\Delta \bar{S}|_{R}=\frac{1}{3 k} \sum_{j=1}^{k} \sum_{i=n_{j}-2}^{n_{j}}\left|S_{i, j}-S_{i-1, j}\right|$.

- $\quad M 11$ statistika sutampa su $M 9$ statistika, jei matuojame paskutinių trijų metų svyravimus.

$$
M 11=\frac{10}{3 k} \sum_{j=1}^{k}\left|S_{n_{j}, j}-S_{n_{j}-2, j}\right| .
$$

Liekanų autokoreliacija, naudojant parametrini ar neparametrini metodus, tikrinama naudojant tris kriterijus - Ljung-Box, Box-Pierce statistikas bei Durbino-Watsono kriterijų.

Liekanų autokoreliacijai nustatyti, tikrinama hipoteze $\mathrm{H}_{0}$ kuri teigia, kad liekanų autokoreliacijos nèra. Tam vertinama statistika Ljung-Box, kuriai skaičiuoti naudojamos dviejų metų liekanų autokoreliacijos. $\mathrm{H}_{0}$ priimama, jei Ljung-Box statistikos reikšmė mažesnè už reikšmingumo lygmens $\alpha$ lygio $\chi_{m}^{2}$ 
skirstinio kvantili $\left(\chi_{m, \alpha}^{2}\right)$, čia $m$ - laisvès laipsniai. Laiko eilutès $y(t)$ stebejjimų $x_{t}$, kai $t=1,2, \ldots, n$ autokoreliaciją su $k$-juoju vèlavimu žymėsime:

$$
r_{k}=\frac{\sum_{t=k+1}^{n} y_{t} y_{t-k}}{\sum_{t=1}^{n} y_{t}^{2}} .
$$

Laiko eilutès Ljung-Box statistika, esant vėlavimui $M$ apskaičiuojama:

$$
Q^{\prime}=n(n+2) \sum_{k=1}^{M} \frac{r_{k}^{2}}{n-k} .
$$

Box-Pierce statistika naudojama $\mathrm{H}_{0}$ hipotezei tikrinti, kuri teigia, kad tarp liekanų nèra sezoninès autokoreliacijos. $\mathrm{H}_{0}$ priimama, kai Box-Pierce statistikos reikšmė yra mažesnè už reikšmingumo lygmens $\alpha$ lygio $\chi_{2}^{2}$ skirstinio kvantili $\left(\chi_{2, \alpha}^{2}\right)$. Box-Pierce statistika, esant vèlavimui $M$ apskaičiuojama pagal formulę:

$$
Q=n \sum_{k=1}^{M} r_{k}^{2} .
$$

Liekanų autokoreliacija vertinama naudojama Durbino-Watsono kriterijaus statistiką:

$$
d=\frac{\sum_{t=2}^{T}\left(\varepsilon_{t}+\varepsilon_{t-1}\right)^{2}}{\sum_{t=1}^{T} \varepsilon_{t}^{2}} .
$$

Hipotezès tikrinimui, kad liekanos autokoreliuotos, pasirinkamas reikšmingumo lygmuo $\alpha$ ir gauta kriterijaus reikšmè palyginama su DurbinoWatsono kriterijaus pasirinkto reikšmingumo lygmens kritinėmis reikšmėmis $\left(d_{L}\right.$ ir $d_{u}$ ). Autokoreliacija reikšminga, jei $d<d_{L}$ arba $d>4-d_{L}$. Liekanų koreliacija statistiškai nereikšminga, jeigu $d_{u}<d<4-d_{u}$. Durbino-Watsono statistika igyja reikšmes nuo 0 iki 4 . Kuo $d$ arčiau 2, tuo mažiau tikètina, kad autokoreliacija reikšminga.

Liekanų nepriklausomumas tikrinamas dviejų kriterijų pagalba - Ljung-Box ir Box-Pierce. Ljung-Box statistikos vertinimui naudojamos dvejų metų liekanų kvadratu autokoreliacijos. $\mathrm{H}_{0}$ priimama, jei Ljung-Box statistikos reikšmé 
mažesnè už pasirinkto reikšmingumo lygmens $\alpha$ lygmens $\chi_{m}^{2}$ skirstinio kvantilị $\left(\chi_{m, \alpha}^{2}\right)$, čia $m$ - laisvès laipsniai (periodų skaičius padaugintas iš dviejų atimant ARIMA koeficientų skaičių).

Box-Pierce statistika naudojama hipotezei $\mathrm{H}_{0}$ tikrinti, kad liekanos yra sezoniškai nepriklausomos. Box-Pierce statistikai skaičiuoti naudojamos autokoreliacijos pirmiems dviems liekanų kvadratų sezoniniams vélavimams. $\mathrm{H}_{0}$ priimta, kai Box-Pierce statistikos reikšmė mažesnè už reikšmingumo lygmens $\alpha$ lygio $\chi_{2}^{2}$ skirstinio kvantili $\left(\chi_{2, \alpha}^{2}\right)$.

Papildomai nestebimų laiko komponenčiu modeliavimo kokybei tikrinti naudojama modelio liekanų spektriné analizè. Sezoninès komponentès eliminavimo stabilumas tikrinamas apskaičiuojant diagnostines statistikas slenkantiems persidengiantiems laiko eilutès intervalams, taip pat vertinamas revizijos dydis.

\subsection{Autoregresiniai SETAR modeliai}

Ivairūs socialiniai, ekonominiai ar politiniai pokyčiai itakoja ekonominių indikatorių laiko eilučių reikšmes - atsiranda struktūriniai laiko eilučių pokyčiai, laiko eilutès dispersija tampa nepastovi laike, didejja laiko eilutès verslo ciklo asimetriškumas $^{1}$, ivyksta kiti laiko eilutės pokyčiai, kurie komplikuoja laiko eilutès modeliavimą (D. Dijk ir B. Silverstovs, 2003). Todèl, daugelį realių laiko eilučių sudètinga, o kartais ir neįmanoma pakankamai tiksliai aprašyti taikant iprastus tiesinius laiko eilučių modeliavimo metodus. Tokiais atvejais naudojami netiesiniai modeliai. Šiame darbe naudoti slenkstiniai autoregresiniai modeliai.

Slenkstiniai autoregresiniai modeliai sudaro didelę stochastinių, su netiesine struktūra, laiko eilučių klasę. SETAR (Self-Exciting Threshold AutoRegressive) modeliai priklauso šiai klasei. Naudojant SETAR modelius, laiko eilučiu reikšmès, pagal specifini slenkstini kintamaji, klasifikuojamos i skirtingus reikšmių poklasius.

SETAR modelius pasiūlè Tong 1978. Tolimesnè šio modelio plètotė ir analizė buvo aprašyta Tong ir Lim 1980 metu ir Tong 1995 metų darbuose. Slenkstiniuose autoregresijos modeliuose (TAR) laiko momento $t$ slenkstis nustatomas lyginant vertinamą kintamaji su slenksčio reikšme $r$. SETAR modeliuose slenksčio kintamasis yra tiriamos laiko eilutės reikšmė su poslinkiu (H. Feng, J. Liu, 2002).

\footnotetext{
${ }^{1}$ Keynes (1936) nustatė, kad verslo ciklo asimetrija įvyksta, kadangi ekonomika elgiasi skirtingai plètros ir recesijos periodais: biznio ciklo kritimai yra trumpesni ir staigesni, nei pakilimai.
} 
Dviejų poklasių slenkstini autoregresijos modeli, naudojant indikatoriaus funkcija, galima užrašyti:

$$
y(t)=\operatorname{Ind}_{1, t-d}(r)\left(\gamma_{1,0}+\sum_{j=1}^{p_{1}} \gamma_{1, j} y(t-j)+e_{1}(t)\right)+\operatorname{Ind}_{2, t-d}(r)\left(\gamma_{2,0}+\sum_{i=1}^{p 2} \gamma_{2, i} y(t-i)+e_{2}(t)\right) .
$$

Čia $\quad \operatorname{In} d_{1, t-d}(r)=\operatorname{Ind}(y(t-d) \leq r)=\left\{\begin{array}{l}1 \text { kai } y(t-d) \leq r \\ 0 \text { kitais atvejais }\end{array}, \quad\right.$ ir $\quad$ atitinkamai $\operatorname{Ind}_{2, t-d}(r)=\operatorname{Ind}(y(t-d)>r)=\left\{\begin{array}{l}1 \text { kai } y(t-d)>r \\ 0 \text { kitais atvejais }\end{array}, t=1, \ldots, n, d-\right.$ vèlavimo parametras, $r$ slenksčio reikšmè, o $e_{i}(t) \sim i i d(0,1), i=1,2$.

Liekanose $e_{i}(i=1,2)$ leidžiamas heteroskedastiškumas (dispersija gali būti nepastovi), kuris priklauso nuo duomenų suskaidymo į reikšmių poklasius.

Modeliuojant laiko eilutes slenksčio kintamasis $r$ nèra žinomas. Šis parametras labai svarbus, nes laiko eilutès reikšmių skaidymas i du reikšmių poklasius tiesiogiai priklauso nuo slenksčio reikšmès. Kai slenksčio kintamasis fiksuotas, SETAR modeliai yra tiesiniai parametrų atžvilgiu. Galimų slenksčio kintamuju aibė $R \equiv\left\{r_{1}, r_{2}, \ldots, r_{k}, \ldots, r_{n}\right\} \subset\left[\min r_{k}, \max r_{k}\right]$, kai $k=1,2, \ldots, n$, turi būti tokia, kad visose reikšmių poklasiuose autoregresijos parametrų apskaičiavimui būtų pakankamai laiko eilutès narių. Praktikoje dažniausiai $r$ parenkamas toks, kad kiekvienas reikšmių poklasis tenkintų $R=\{r \mid y([\pi(n-1)]) \leq r \leq y([(1-\pi)(n-1)])\}$ (H. Feng, L. Lui, 2002). Griežtos procedūros, pagal kurią būtų nustatomas slenksčio kintamasis $r$ ir poslinkio parametras $d$ nèra nusakytos. Dažniausiai jie parenkami taip, kad būtų minimizuojama vidutinè kvadratinè paklaida, vidutiné absoliutinè paklaida, kvadratinių liekanų suma ar Akaike informacinis kriterijus (AIC).

SETAR modelio parametrus, kai fiksuotas slenksčio kintamasis, galima ivertinti naudojant mažiausių kvadratų metodą.

\subsection{Modelio vertinimo pagrindimas: tyrimo metodika, algoritmai ir analizè}

Vienas iš ekonometrijos tikslų yra, išanalizavus ekonominių laiko eilučiuc désningumus, rasti matematinius metodus, kurių pagalba galima ne tik nustatyti ekonominių indikatorių tarpusavio ryšius, aprašyti tiriamą laiko eilutę, bet ir analizuoti i̇vairių ekonominių šokų itaka, prognozuoti ir t.t. Egzistuoja nemažai skirtingų ekonometrinių metodų, kuriuos galima naudoti ekonominių laiko eilučių modelių vertinimui. Tačiau norint sudaryti modelius, kurie adekvačiai 
reaguotų i̇ ivvairius ekonominius impulsus būtina išanalizuoti tiriamų laiko eilučių struktūrą. Dèl per palyginus trumpą laikotarpi sparčiai besikeičiančių ekonominių, socialinių bei politinių sąlygų Lietuvoje, šalies ekonominių indikatorių laiko eilutès pakankamai sudètingos ir todèl dažniausiai neįmanoma jas aprašyti naudojant tradicinius ekonometrinius metodus.

Nuodugniai išanalizavus Lietuvos ekonominių indikatorių struktūrą ir jų modeliavimo galimybes, pasiūlyta nauja modelio lygčių sudarymo metodika, pagrista disertaciniame darbe aprašytais tyrimais. Toliau pateikiama modeliuotu laiko eilučių nestebimų komponenčių vertinimo metodų lyginamoji analizė, kurios rezultatai pritaikyti kuriant modeliavimo metoda, aprašytas ASETAR metodo parametrų vertinimo algoritmas, kuris naudojamas sudètingos prigimties laiko eilučių modeliavimui.

\subsubsection{Laiko eilučių komponenčių nustatymo analizè}

Norint nustatyti, ar spektrinès analizès rezultatai patikimai nustato nestebimas laiko eilučių komponentes, buvo naudotos modeliuotos laiko eilutès. Nagrinèta 800 skirtingų modeliuotų laiko eilučių, sudarytų iš trendo, sezoninès ir atsitiktinė komponentès. Imituojant realias ekonominiu indikatorių laiko eilutes, pasirinktos dvi skirtingos, sudètingesnio tipo, trendo funkcijos:
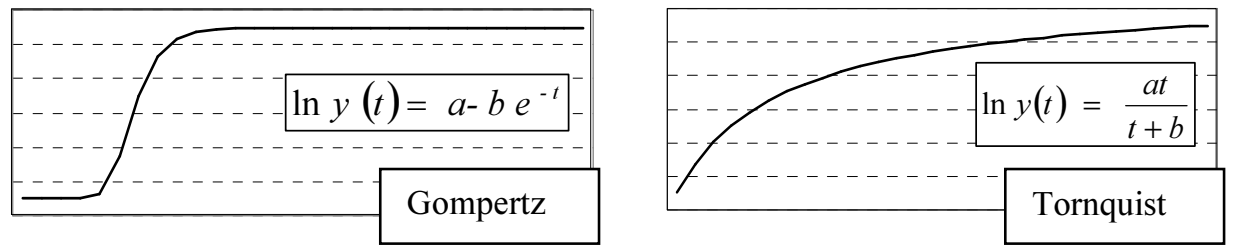

2.5 pav. Modeliuotų laiko eilučių trendo funkcijos

Fig. 2.5. Trend functions of simulated time series

Sudarytos keturių rūšių sezoninès komponentès: stabili, kintanti laiko atžvilgiu, stabili su atsitiktiniais svyravimais ir kintanti laiko atžvilgiu su atsitiktiniais svyravimais. Sumodeliuota 100 skirtingu atsitiktinès komponentès eilutès determinuotos nestebimos komponentès. Galutinès modeliuotos laiko eilutès apskaičiuotos naudojant adityvų modelį:

$$
y(t)=\sum_{i} U_{i}(t)=T(t)+S(t)+I R(t), T=1,2, \ldots, 64 .
$$

Norint patikrinti teigini apie spektrinès analizès patikimumą nustatant nestebimas laiko eilutès komponentes, modeliuotoms laiko eilutėms buvo sudaryti spektrinių funkcijų grafikai. Kad neišplèstume šio darbo apimties, čia 

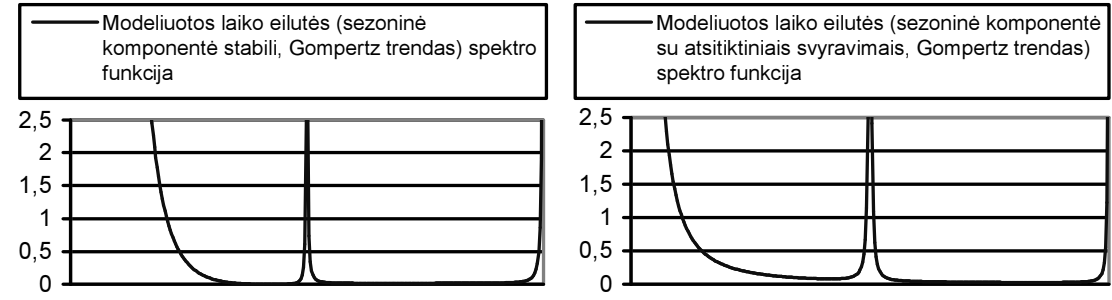

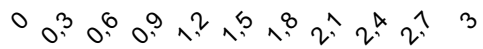

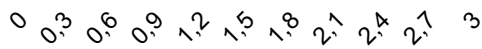
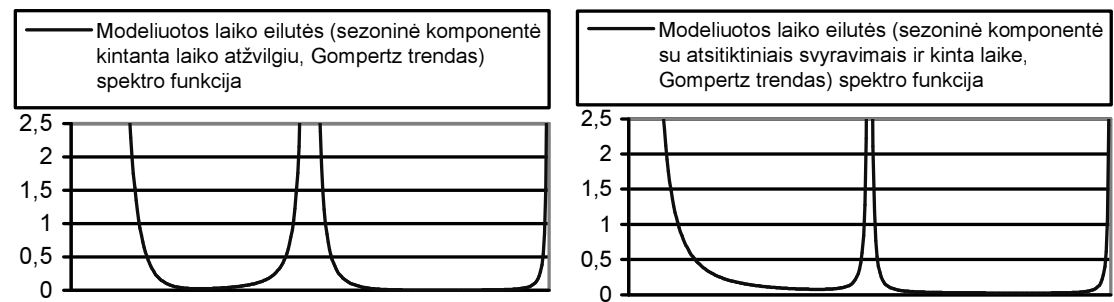

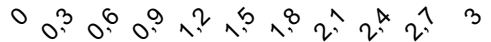

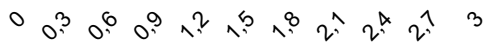
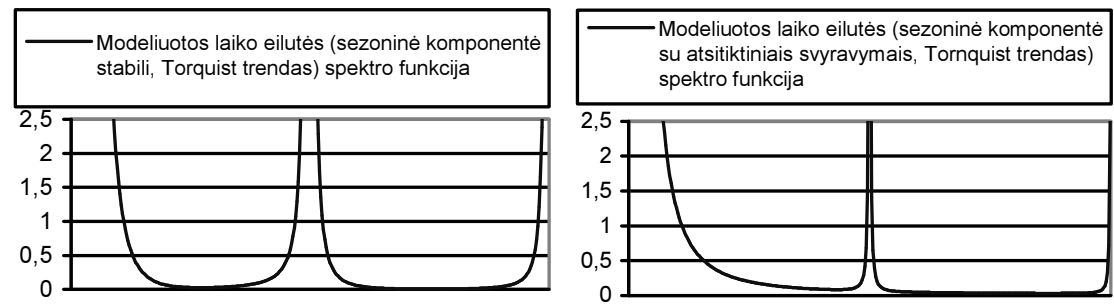

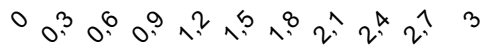

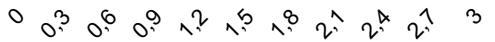
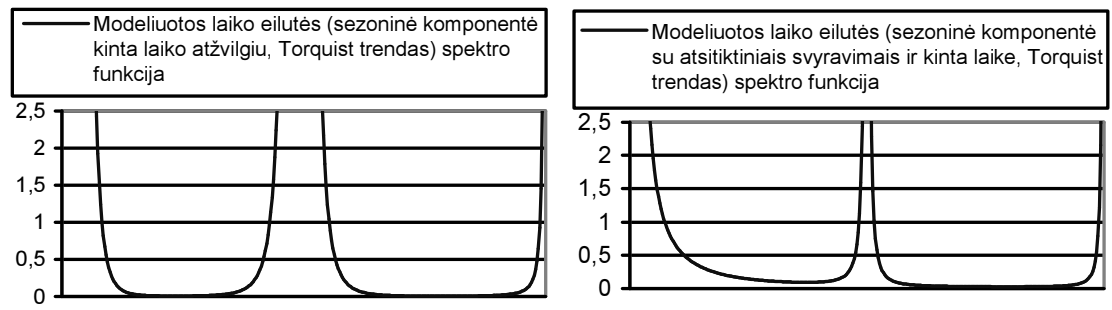

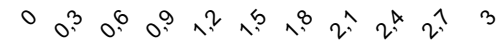

0 0. 0.0 .2 .

2.6 pav. Modeliuotų laiko eilučių spektrinès funkcijos

Fig. 2.6. Spectral functions of simulated time series

pateiksime tik po vieną skirtingo trendo ir sezoninès komponentès analizuotu laiko eilučiu atveji. 
Norint patikrinti teigini apie spektrinès analizès patikimumą nustatant nestebimas laiko eilutès komponentes, modeliuotoms laiko eilutėms buvo sudaryti spektrinių funkcijų grafikai. 2.6 paveiksle pavaizduoti skirtingo trendo ir sezoninès komponentès analizuotų laiko eilučių atvejai.

Visų modeliuotų laiko eilučiu spektrinių funkcijų grafikų pikai, nepriklausomai nuo trendo ir sezoninės komponentès tipo, buvo pasiekti trijuose taškuose $\omega=0, \omega=\frac{\pi}{2}$ ir $\omega=\pi$, kurie rodo, kad tirtos laiko eilutès turi trendą bei sezoninę komponentę, kurios pikai kartojasi du kartus per metus. Atliktos analizès rezultatai patvirtina teigini, jog spektrinè analizè pakankamai tiksliai nurodo laiko eilutès nestebimas komponentes, nepriklausomai nuo laiko eilutès trendo pavidalo, sezoniškumo tipo ar atsitiktinès komponentès svyravimų. Todèl, remiantis gautais rezultatais, nuspręsta, prieš sudarant šalies ekonominių indikatoriu modelio lygtis, visiems endogeniniams ir egzogeniniams rodikliams atlikti spektrinę analizę.

Analizuojant realias Lietuvos ekonominių indikatorių laiko eilučių spektro funkcijas nustatyta, kad dauguma jų turi reikšmingą sezoninę komponentę. Atlikus detalią analizę ir lyginant modeliavimo rezultatus su faktiniais nustatyta, kad modeliuojant atskiras komponentes gaunamos mažesnès modeliu ir prognozès paklaidos. Todèl modeliuojant atskirų ekonominių indikatorių laiko eilutes, išskirtos nestebimos laiko eilučių komponentès.

\subsubsection{Laiko eilučių nestebimų komponenčių vertinimo metodų lyginamoji analizè}

Laiko eilučių nestebimų komponenčių vertinimo metodų lyginamosios analizès tikslas - nustatyti kuris iš metodu geriausiai įvertina laiko eilučių nestebimas komponentes. Laiko eilučių nestebimų komponenčių vertinimo metodų palyginimui naudotos spektrinei analizei paruoštos modeliuotos laiko eilutès. Papildomai buvo sumodeliuota dar 800 laiko eilučių, kurių atsitiktinès komponentès dispersija reikšmingai kinta laike.

Kadangi modeliuotų laiko eilučių nestebimos komponentès žinomos tiksliai, tai lyginant metodus vertinamos trendo ir sezoninès komponentès gautu iverčiu modelis $y(t)=\hat{T}(t)+\hat{S}(t)+\varepsilon(t)$, bei laiko eilutès modelio $y(t)=\hat{T}(t)+\hat{S}(t)+\hat{I}(t)$ paklaidos, čia $\hat{T}(t)$ - trendo ivertis, $\hat{S}(t)$ - sezoninès komponentès ivertis, $\hat{I}(t)$ - atsitiktinè komponentès įvertis. Rezultatų palyginimui naudota vidutinès santykinè absoliutinè paklaida (VSAP): 


$$
V S A P=N^{-1} \sum_{i=1}^{N} \frac{|y(t)-\hat{y}(t)|}{y(t)}
$$

ir vidutinè santykinè kvadratinè paklaida (VSKP):

$$
V S K P=\sqrt{N^{-1} \sum_{i=1}^{n} \frac{(y(t)-\hat{y}(t))^{2}}{y^{2}(t)}} .
$$

Čia $N$ laiko eilutès narių skaičius, $\hat{y}(t)$ - laiko eilučių nestebimų komponenčių vertinimo metodais įvertinta reikšmè.

Tikslesniu laiko eilučių nestebimų komponenčių vertinimo metodu laikomas tas, kurio įvertinto modelio ir atskirų laiko eilutès nestebimų komponenčių VSAP ir VSKP paklaidos yra mažesnès. Jei atskiros komponentès geriau įvertinamos skirtingais metodais, tai geresniu laikomas tas, kuris geriau ịvertina visą modeli. Jei viena iš paklaidų mažesnè naudojant vieną metodą, o kita paklaida mažesné naudojant kitą metodą, tai šie metodai laikomi lygiaverčiais.

Modelių tikslumas ir tinkamumas nustatytas ne tik pagal aukščiau aprašytas VSAP ir VSKP, bet ir tikrinant liekanu autokoreliacija, nepriklausomuma, liekanų pasiskirstymą pagal normaluji dèsni, bei apskaičiuojant standartines diagnostines statistikas, aprašytas 2.1 .5 skyrelyje.

Analizei atlikti buvo naudojama Europos Bendrijos Statistikos tarnybos (Eurostat) aprobuota programine iranga Demetra, TRAMO-SEATS, Belgijos banko naudojama programa NBBTools ir darbo autorés sukurta programa.

Ivvertinus modeliuotų laiko eilučių nestebimas komponentes, gauta, kad nestebimų laiko eilučių komponenčių išskyrimo rezultatai gana panašūs, tiek naudojant parametrinius, tiek neparametrinius metodus. Skirtingi trendo funkcijos pavidalai neįtakojo gautų rezultatų. Todèl čia pateiksime tik suvestinę lentelę:

2.2 lentelè. Laiko eilučių modelių vidutinès paklaidos

\begin{tabular}{|c|c|c|}
\hline \multirow[b]{2}{*}{$\begin{array}{l}\text { Modeliavimo } \\
\text { metodas }\end{array}$} & \multicolumn{2}{|c|}{ Vidutinès paklaidos, proc. } \\
\hline & $\begin{array}{l}\text { Vidutinė santykinė absoliutinè } \\
\text { paklaida }\end{array}$ & $\begin{array}{l}\text { Vidutinè santykine } \\
\text { kvadratinè paklaida }\end{array}$ \\
\hline Parametrinis & 0,74 & 1,03 \\
\hline Neparametrinis & 0,71 & 1,28 \\
\hline
\end{tabular}

Table 2.2. Average model error of time series

Išsamios lentelès su gautom paklaidom, pagal pasirinktą trendo funkciją ir sezono komponentę, pateiktos A priede.

Naudojant neparametrinius metodus, modelio VSAP mažesnè, nei naudojant parametrinius, o VSKP atvirkščiai - mažesnè naudojant parametrinius metodus. 
Vertinant trendo ir sezoninès komponentès įverčius, mažesnès vidutinès paklaidos gautos naudojant parametrinį metodą. Galime daryti išvadą, kad laiko eilučių, kurių atsitiktinès komponentès dispersija reikšmingai nekinta laiko atžvilgiu, nestebimas komponentes geriau vertina parametriniai metodai. Kadangi paklaidos skiriasi nedaug, tai tiek parametriniai, tiek ir neparametriniais metodai taikytini laiko eilučių nestebimų komponenčių vertinimui.

Analizuojant laiko eilučiuc, kurių atsitiktinès komponentès dispersija reikšmingai kinta laike, modeliavimo rezultatus, gauta, kad laiko eilučių modelių abi paklaidos mažesnès naudojant neparametrinị metodą (2.3 lentelè).

2.3 lentelè. Laiko eilučių, su nestabilia atsitiktine komponente, modelių vidutinės paklaidos

Table 2.3. Average model error of time series with unstable irregular component

\begin{tabular}{|l|c|c|}
\hline \multirow{2}{*}{$\begin{array}{c}\text { Modeliavimo } \\
\text { metodas }\end{array}$} & \multicolumn{2}{|c|}{ Vidutinès paklaidos, proc. } \\
\cline { 2 - 3 } & $\begin{array}{c}\text { Vidutinè santykinè absoliutinè } \\
\text { paklaida }\end{array}$ & $\begin{array}{c}\text { Vidutinè santykinė } \\
\text { kvadratinė paklaida }\end{array}$ \\
\hline Parametrinis & 2,17 & 5,14 \\
\hline Neparametrinis & 2,11 & 3,68 \\
\hline
\end{tabular}

Analizuojant laiko eilučiuc, kurioms eliminuota sezoninè komponente bei modeliu liekanų spektrinių funkcijų grafikus, M1, M3-M11 (tik X-12-ARIMA metodui), Ljung-Box, Box-Pierce Durbin-Watson statistikas nustatyta, kad tiksliausiai nestebimas laiko eilučių komponentes įvertina neparametrinis metodas. Parametrinis metodas taip pat tinkamas, bet gauti rezultatai šiek tiek blogesni.

\subsubsection{ASETAR modelis ir jo vertinimo algoritmas}

Kuriant Lietuvos ekonominio modelio lygtis pastebèta, kad nemažai laiko eilučių nepavyksta pakankamai tiksliai aprašyti, naudojant iprastus ekonometrinius mechanizmus. Todèl buvo ieškomi nauji efektyvesni metodai, kurie suteiktų galimybę vertinti visus vedančiuosius šalies ekonominius indikatorius su pakankamu patikimumu. Pasinaudojus atliktais tyrimais disertaciniame darbe ir esama moksline literatūra pasiūlytas naujas metodas sudètingos prigimties laiko eilučiuc, kurioms nepavyksta pritaikyti tradicinių tiesinių metodų, modeliavimui - adaptuotas slenkstinis autoregresinis metodas.

SETAR modeliai kol kas nèra dažnai taikomi praktikoje, dèl kylančių problemų pasirenkant teisingą modelio eilę, sudètingos slenkstinio kintamojo ir poslinkio parametro nustatymo procedūros, o Lietuvoje atliktų tyrimų naudojant SETAR tipo modelius rasti nepavyko. Tačiau išanalizavus esamą mokslinę literatūrą buvo rasti keletas skirtingų būdų kaip išvengti šių problemų. Praktiniuose uždaviniuose šios problemos dažniausiai sprendžiamos naudojant 
Akaike informacini kriterijų (AIC). SETAR modeliams AIC kriterijus apibrezžiamas kaip AR modelių skirtinguose poklasių AIC kriterijų suma. Akaike kriterijus buvo taikomas ir sprendžiant disertacijoje iškeltus uždavinius.

Šiame darbe teikiamas adaptuotas SETAR modelis, kuris turi netiesinių modelių vertinimo galimybę, ivertinant nestebimų laiko eilučiu komponenčiu svarbą. Dèl aiškesnio pateikimo čia aprašytas tik dviejų poklasių adaptuoto SETAR modelio algoritmas, tačiau siūloma metodika gali būti taikoma ir vertinant modelius su daugiau nei dviem poklasiais. Šio modelio realizacijos algoritmas pavaizduotas 2.7-2.9 paveiksluose.

Toliau pateikiama siūlomo ASETAR modelio vertinimo metodika, kuri suskirstyta i atskirus etapus:

1-5 etapai. Dauguma realių laiko eilučių turi išskirčių, struktūrinių pokyčių, o taip pat reguliarių sezoninių ar nereguliarių svyravimų, kuriuos sudètinga ivertinti naudojant iprastus modeliavimo metodus. Todèl, prieš modeliavima, atliekami laiko eilutès koregavimai ir „trukdančių” komponenčių eliminavimas naudojant 2.1.4 skyrelyje aprašytus metodus. Trendo, ciklo, sezoninès komponentès gali būti vertinamos naudojant parametrinius ar neparametrinius metodus. Lyginamoji šių metodų analize pateikta 2.3.2 skyrelyje.

Prieš pereinant $i$ kitą etapą, patikrinamas atsitiktinès komponentès netiesiškumas. Modeliuojamų laiko eilučių netiesiškumui nustatyti naudojamas RESET (Ramsey Regression Equation Error Test) testas. RESET skirtas neitrauktų i regresijos lygti kintamuju aptikimui ir nekorektiškai parinktos regresijos funkcijos formos nustatymui.

Jei $y(t)=\beta_{1}+\beta_{2} x_{2}(t)+\ldots+\beta_{n} x_{n}(t)+\varepsilon(t)$ - ivertintas regresijos modelis, o pagal ši modeli apskaičiuotos reikmès lygios $\hat{y}(t)=b_{1}+b_{2} x_{2}(t)+\ldots+b_{n} x_{n}(t)$, tai RESET testas tikrina ar bet vienas iš $\gamma_{1} \hat{y}^{2}(t), \gamma_{2} \hat{y}^{3}(t), \ldots, \gamma_{k-1} \hat{y}^{k}(t)$ reikšmingai itakoja $y(t)$. Tam vertinamas modelis $y(t)=\beta_{1}+\beta_{2} x_{2}(t)+\ldots+\beta_{n} x_{n}(t)+\gamma_{1} \hat{y}^{2}(t)+\gamma_{2} \hat{y}^{3}(t)+\ldots+\gamma_{k-1} \hat{y}^{k}(t)+\varepsilon(t) \quad$ ir $\mathrm{F}$ statistikos pagalba tikrinama nulinè hipotezè $\mathrm{H}_{0}: \gamma_{1}=\gamma_{2}=\ldots=\gamma_{k}=0$ su alternatyva $\mathrm{H}_{\mathrm{A}}: \gamma_{1} \neq 0$ arba $\gamma_{2} \neq 0 \ldots$ arba $\gamma_{k} \neq 0$. Atmetus $\mathrm{H}_{0}, \mathrm{kad}$ visi regresijos lygties netiesinių narių koeficientai lygūs 0 , daroma išvada, kad modelis gali būti pagerintas, naudojant netiesinius elementus.

RESET testas skirtas bendrai netiesiškumo formai aptikti. Naudojant ši testą nenustatoma ar netiesiškumas gali būti aprašomas slenkstiniais modeliais.

Slenkstinio netiesiškumo aptikimui siūloma naudoti kitą testą. Kadangi SETAR (1) modelis ir jo parametrai vertinami viename poklasyje, tai ji galima priskirti tiesinių autoregresinių modelių klasei. Todèl slenkstiniam netiesiškumui nustatyti galime naudoti nulinę hipotezę $\operatorname{SETAR}(1)$ su alternatyva $\operatorname{SETAR}(m)$, 
čia $m>1$. Detaliau tiesinių modelių testavimas su alternatyva SETAR aprašytas K.S. Chan (1990) ir E. H. Hansen (1999) darbuose, kur nulinès hipotezès atmetimui bendruoju atveju siūlyta taikyti F-kriterijų:

$$
F_{j k}=N\left(\frac{S_{j}-S_{k}}{S_{k}}\right) .
$$

Čia $S_{j} \operatorname{SETAR}(j)$ modelio kvadratinių liekanų suma (tiesinis modelis - nulinè hipotezè), $S_{k}-\operatorname{SETAR}(k)$ kvadratinių liekanu suma.

Ši testą galima naudoti ir norint nustatyti slenkstinio autoregresinio modelio tipa, pvz. tikrinant hipotezę $\operatorname{SETAR(2)~su~alternatyva~} \operatorname{SETAR}(m)$, čia $m>2$, galima nustatyti kiek poklasių turintis SETAR modelis turimus duomenis aprašo geriausiai.

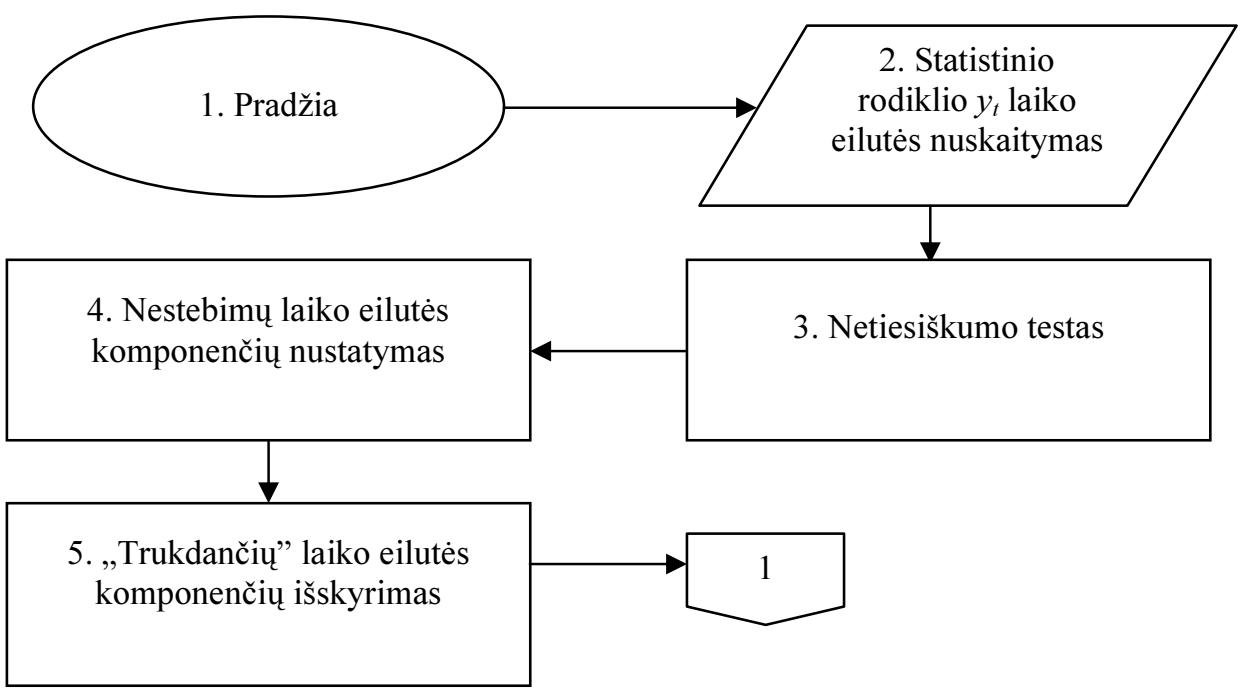

2.7 pav. ASETAR modelio parametrų vertinimo algoritmo 1-5 etapai Fig. 2.7. ASETAR model parameter estimation algorithm, 1-5 stages

6-9 etapai. Šiame etape vertinami SETAR modelio vèlavimo parametras $d$ ir slenksčio kintamasis $r$. Kadangi nagrinètos laiko eilutès nèra pakankamai ilgos, tai darbe buvo atsiribota dviejų poklasių SETAR modeliu: 


$$
\begin{aligned}
y(t)= & \operatorname{Ind}_{1, t-d}(r)\left(\gamma_{1,0}+\sum_{j=1}^{p_{1}} \gamma_{1, j} y(t-j)+e_{1}(t)\right)+ \\
& +\operatorname{Ind}_{2, t-d}(r)\left(\gamma_{2,0}+\sum_{i=1}^{p 2} \gamma_{2, i} y(t-i)+e_{2}(t)\right) .
\end{aligned}
$$

Pirmiausia užfiksuojamas vèlavimo parametras $d$, kuris negali būti didesnis už $N-1$, kai $N$ yra modeliuojamos laiko eilutès ilgis. Vèlavimo parametras $d$ turi būti toks, kad būtų imanoma adekvačiai ịvertinti modelio parametrus. Kadangi šiame darbe analizuojamos laiko eilutès nèra labai ilgos, tai pasirinktas apribojimas, kad vėlavimo parametras neviršytų dviejų metų laiko eilutės stebejjimų skaičiaus.

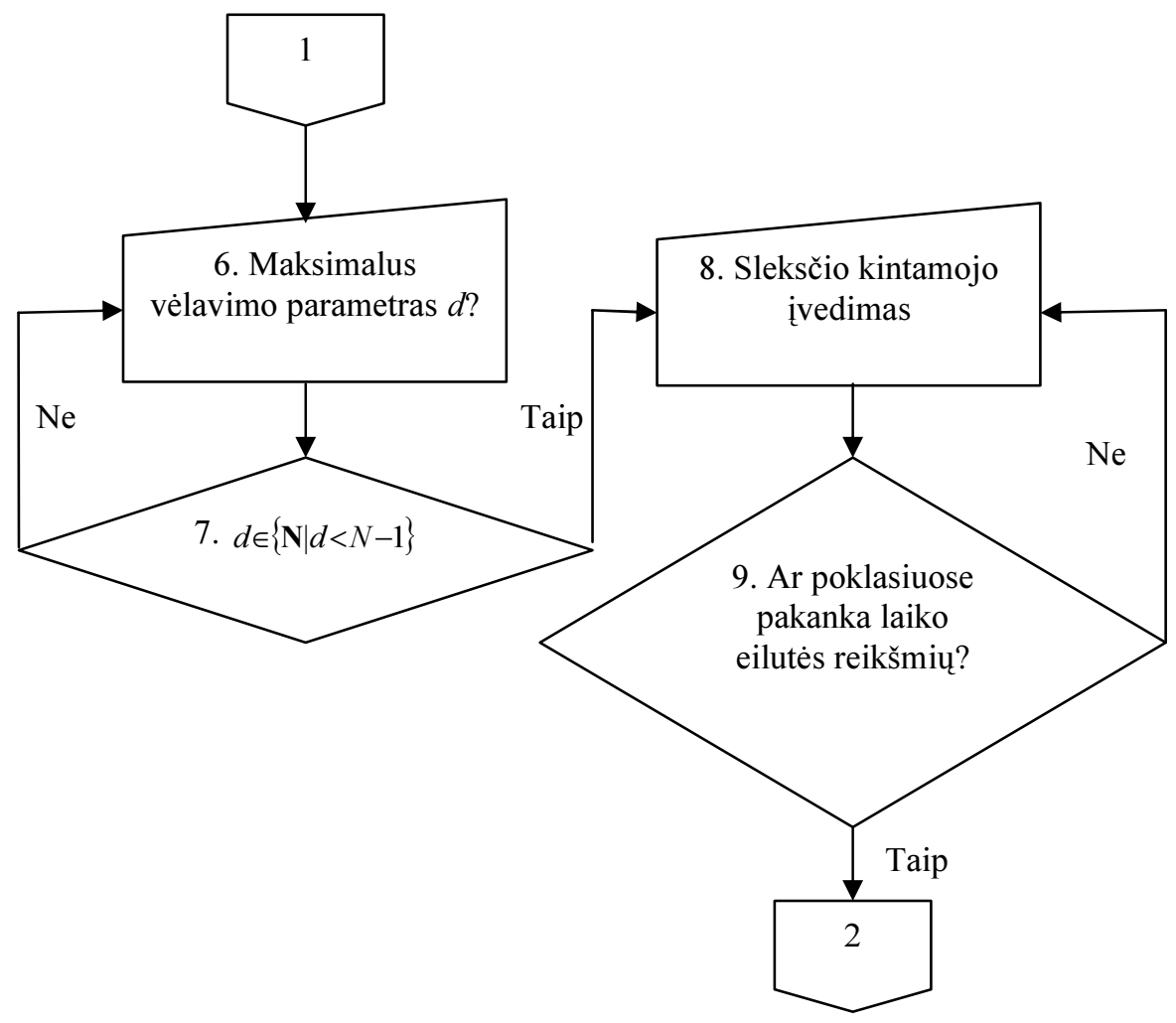

2.8 pav. ASETAR modelio parametrų vertinimo algoritmo 6-9 žingsniai

Fig. 2.8. ASETAR model parameter estimation algorithm, 6-9 steps 
Toliau pasirenkamas slenksčio kintamasis $r$. Galimų slenksčio kintamujų reikšmių aibe $R=\left\{r_{i}\right\}$ turi būti tokia, kad kiekvienas modelio poklasis turètu pakankamai laiko eilutės narių autoregresijos parametrų vertinimui. Kaip jau minèta 2.2 skyrelyje, praktikoje dažniausiai $R$ parenkamas toks, kad kiekvienas reikšmių poklasis tenkintų

$$
R=\{r \mid y([\pi(n-1)]) \leq r \leq y([(1-\pi)(n-1)])\} .
$$

Čia $\pi$ yra laiko eilutès stebèjimų dalis, o $y_{(0)}, y_{(1)}, \ldots, y_{(n-d)}$ surūšiuotos didèjimo tvarka slenksčio kintamojo $r$ reikšmès, t. y. $y_{(0)} \leq y_{(1)} \leq \ldots \leq y_{(n-d)}$, o [] reiškia sveikają skaičiaus dalį. Rekomenduojama minimali laiko eilutès stebejjimų dalies $\pi$ reikšmė yra 0,15 (Franses; van Dijk; 2000), todèl tikrinama, kad i kiekvieną reikšmių poklasi patektų ne mažiau nei 15 proc. stebejjimų. Jei stebejjimų bus mažiau, tai ịvertinti parametrai gali būti nestabilūs ir nepatikimi, arba iš vis nebus įmanoma juos apskaičiuoti.

10-20 etapai leidžia patikslinti laisvai pasirinktų slenksčio kintamojo $r$ ir vèlavimo parametro $d$ reikšmes. Laisvai pasirinktiems parametrams $d$ ir $r$, pritaikyti individualūs autoregresijos modeliai. Kiekvieno modelio eilè parenkama atsižvelgiant i AIC kriterijų. Po to keičiama slenksčio reikšmè $r$, o vèlavimo parametras $d$ fiksuojamas. Atrenkama tokia $r$ reikšmé, su kuria AIC reikšmė mažiausia. Kitame etape fiksuojama slenksčio reikšmė $r$ ir keičiamas tik vèlavimo parametras $d$. Geriausiu modeliu laikoma ta $d$ reikšmé su kuria minimizuojamas Akaike informacinis kriterijus (AIC). Slenkstiniams modeliams AIC kriterijus apibrèžiamas (Tong, 1990) kaip ivvertintų AR modelių skirtinguose poklasiuose, AIC reikšmių suma:

$$
\operatorname{AIC}\left(p_{1,} p_{2}\right)=n_{1} \ln \hat{\sigma}_{1}^{2}+n_{2} \ln \hat{\sigma}_{2}^{2}+2\left(p_{1}+1\right)+2\left(p_{2}+1\right),
$$

čia $\hat{\sigma}_{j}^{2}, j=1,2$, yra liekanų $j$-jame poklasyje dispersija.

Atrenkamos tokios slenksčio kintamojo $r$ ir vèlavimo parametro $d$ reikšmès, su kuriomis AIC mažiausias.

Kai slenksčio kintamasis ir veelavimo parametras užfiksuoti, adaptuoto SETAR modelio parametrai ivvertinami naudojant standartinius regresinès analizès metodus - mažiausių kvadratų, arba maksimalaus tikètinumo, kurie detaliau aprašyti 2.1.4 skyrelyje.

10-20 etapo schema pateikta 2.9 paveiksle. 


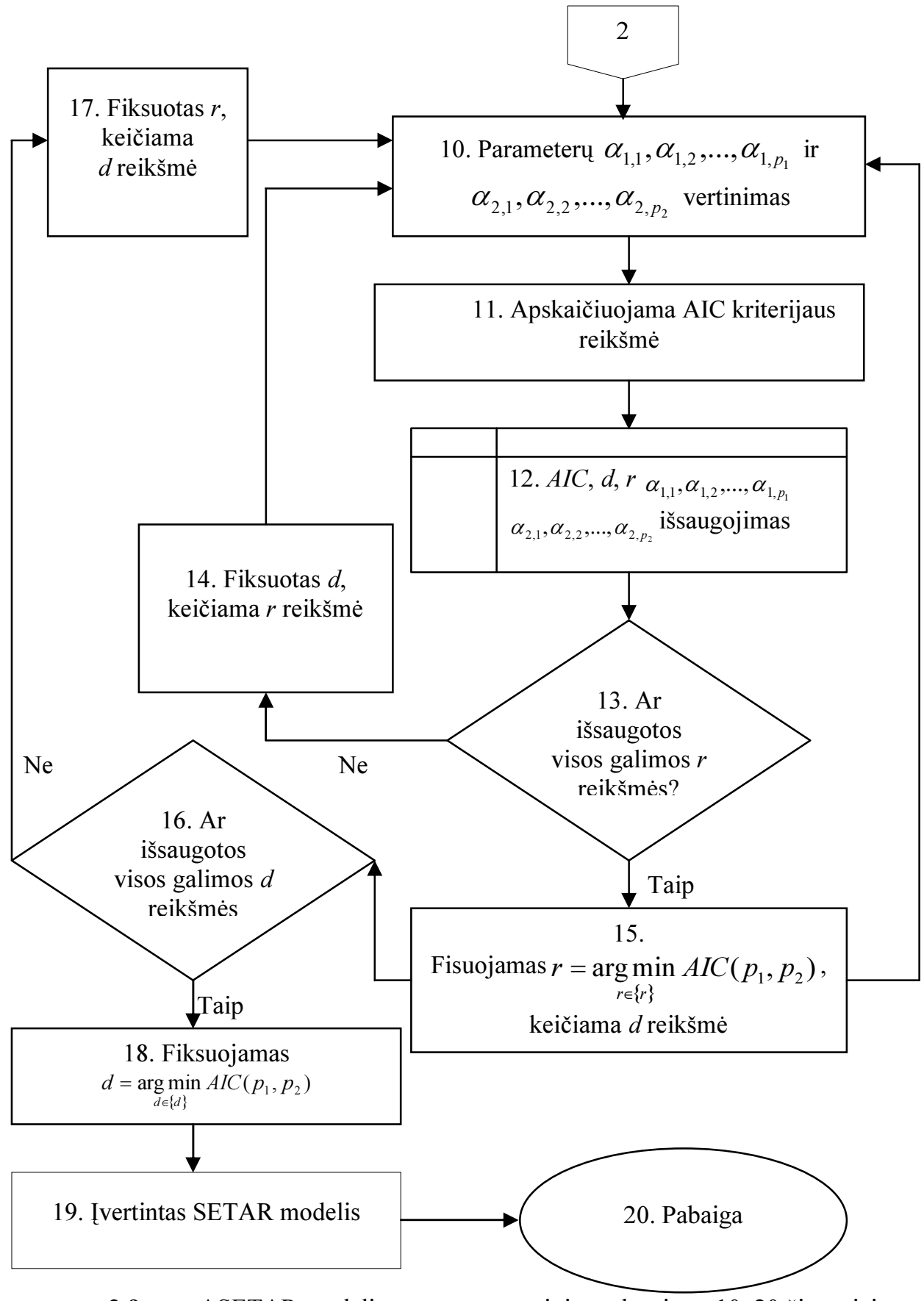

2.9 pav. ASETAR modelio parametrų vertinimo algoritmo 10-20 žingsniai

Fig. 2.9. ASETAR model parameter estimation algorithm, 10-20 steps 


\subsubsection{ASETAR ir ARIMA modelių lyginamoji analizè}

Adaptuoto SETAR metodo aprobavimui, buvo naudojamos realios ir modeliuotos laiko eilutès. Modeliuotos laiko eilutès išsamiau aprašytos 2.3.1 skyrelyje, o realių laiko eilučių modeliavimui pasirinktos 12 grupių suderinto vartotojų kainų indekso (SVKI) mènesinio dažnumo laiko eilutès nuo 1996 metų sausio mèn. iki 2009 metu gruodžio mèn. (168 stebejjimai). Kadangi minètoms eilutėms aprašyti taikomi multiplikatyvūs modeliai, tai vertinant parametrus laiko eilutèms buvo taikyta logaritminè transformacija.

Bendrai netiesiškumo formai tikrinti SVKI laiko eilutems buvo naudotas RESET testas, o slenkstiniam netiesiškumui F-kriterijus, kurie išsamiau aprašyti 2.3.3 skyrelyje. Gauti rezultatai pateikti 2.4 lenteleje: apskaičiuota RESET statistikos reikšme ir jos reikšmingumo lygmuo p-value, kintamojo, reikšmingai itakojančio $y_{t}$, netiesiškumą laipsnis $(h)$, vèlavimo parametras ir F-statistikos reikšme:

2.4 lentelè. Netiesiškumo testų rezultatai

Table 2.4. Results of nonlinearity tests

\begin{tabular}{|l|c|c|c|c|c|}
\hline \multirow{2}{*}{$\begin{array}{l}\text { Suderintas vartotojų } \\
\text { kainų indeksas }\end{array}$} & \multicolumn{2}{|c|}{ RESET testas } & \multicolumn{2}{c|}{ Slenkstinio netiesiškumo testas } \\
\cline { 2 - 6 } & $\begin{array}{c}\text { RESET } \\
\text { statistika }\end{array}$ & p-value & $\mathrm{h}$ & $\begin{array}{c}\text { Vèlavimo } \\
\text { parametras }\end{array}$ & $\begin{array}{c}\text { F-statistika } \\
\text { SETAR(1) vs } \\
\text { SETAR(2) }\end{array}$ \\
\hline $\begin{array}{l}\text { Maistas ir } \\
\text { nealkoholiniai } \\
\text { gerimai }\end{array}$ & 8,4458 & 0,0042 & 2 & 1 & 14,1521 \\
\hline $\begin{array}{l}\text { Alkoholiniai } \\
\text { gerimai, tabakas }\end{array}$ & 2,0390 & 0,1553 & 3 & 8 & 19,8442 \\
\hline Apranga ir avalynė & 2,6575 & 0,1051 & 3 & 11 & 3,8367 \\
\hline $\begin{array}{l}\text { Būstas, vanduo, } \\
\text { elektra, dujos ir } \\
\text { kitas kuras }\end{array}$ & 6,5197 & 0,0117 & 2 & 12 & 10,4923 \\
\hline $\begin{array}{l}\text { Būsto apstatymo, } \\
\text { namų ūkio iranga ir } \\
\text { kasdieninè namų } \\
\text { priežiūra }\end{array}$ & 5,5619 & 0,0196 & 4 & 12 & 5,7670 \\
\hline Sveikata & 2,4429 & 0,1201 & 3 & 11 & 6,6974 \\
\hline Transportas & 5,1110 & 0,0251 & 2 & 1 & 7,1669 \\
\hline Ryšiai & 4,1340 & 0,0437 & 3 & 2 & 10,4452 \\
\hline Poilsis ir kultūra & 2,0849 & 0,1508 & 2 & 11 & 8,3700 \\
\hline Švietimas & 7,2487 & 0,0078 & 2 & 1 & 21,6340 \\
\hline $\begin{array}{l}\text { Restoranai ir } \\
\text { viešbučiai }\end{array}$ & 2,6015 & 0,1087 & 4 & 4 & 5,9740 \\
\hline $\begin{array}{l}\text { Ivairios prekès ir } \\
\text { paslaugos }\end{array}$ & 4,6926 & 0,0318 & 2 & 1 & 8,2807 \\
\hline
\end{tabular}


Alkoholinių gèrimų, tabako, aprangos ir avalynès, sveikatos, poilsio ir kultūros, restoranų ir viešbučių laiko eilutėms buvo priimta nulinè RESET testo hipotezè, kuri parodè, kad šioms laiko eilutems bendrasis netiesiškumas nenustatytas. Tačiau, tikrinant slenkstini netiesiškumą naudojant F-statistika, visoms SVKI prekių ir paslaugų grupėms aptiktas slenkstinis netiesiškumas su skirtingais vèlavimo parametrais. Todèl norint išsamiau išanalizuoti adaptuoto SETAR modelio taikymo galimybes bei ištirti RESET testo patikimumą slenkstiniam netiesiškumui nustatyti buvo nuspręsta tyrime palikti visas laiko eilutes.

Naudojant 2.3.3 skyrelyje pasiūlytą algoritma, SVKI laiko eilutems buvo ivertinti dviejų poklasių SETAR modeliai. Adaptuotu SETAR modelių specifikacijos pateiktos B priede, o poklasių keitimo grafikai - C priede.

Adaptuoto SETAR modelio ịverčių rezultatai buvo palyginti su dažniausiai naudojamo laiko eilučiu analizejje ARIMA modelio rezultatais.

Noredami neišplèsti šio darbo apimties, čia pateiksime tik dviejų SVKI grupių ivvertintų modeliu grafikus - maisto ir nealkoholinių gèrimų bei poilsio ir kultūros. Pirmoji grupe pasirinkta dèl didžiausio svorio vartotojų kainų indekso krepšelyje ir reikšmingų abiejų netiesiškumo testų patvirtinimo. Antroji grupe pasirinkta dèl prieštaringų išvadų nustatant netiesiškumą. Kitų grupių i̇vertintų modeliu grafikai pateikti D disertacijos priede.
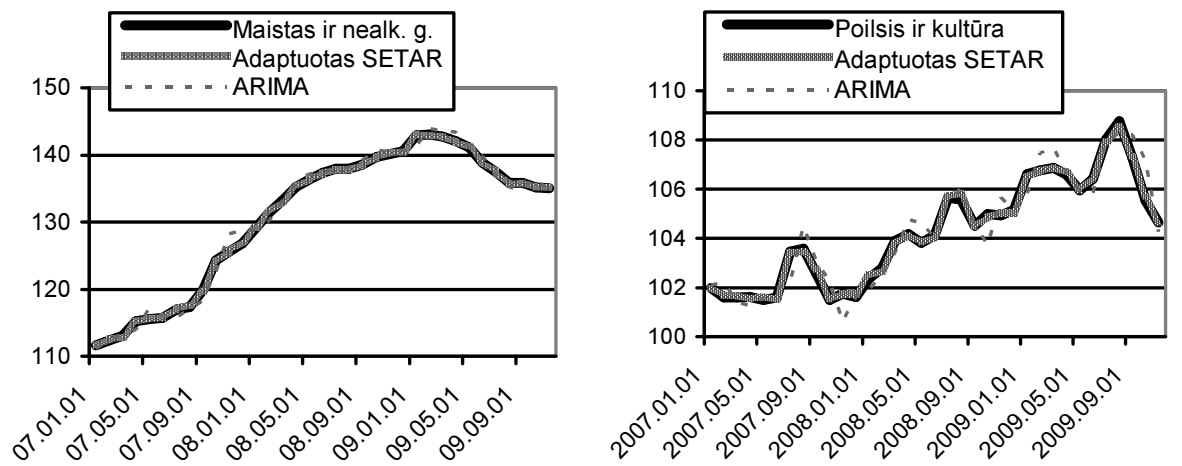

2.10 pav. SVKI modeliavimo rezultatai

Fig. 2.10. Results of HCPI modeling

Iš pateiktu grafikų matome, adaptuotas SETAR modelis geriau aprašo duomenis, nei ARIMA modelis, nes adaptuoto SETAR modelio ivvertinių nuokrypiai nuo realių reikšmių mažesni, nei ARIMA modelių. Tikslesniam gautų rezultatų palyginimui apskaičiuota modelių vidutinè absoliutiné santykinė paklaida. Rezultatai pateikti 2.5 lentelèje. 
2.5 lentelè. ASETAR ir ARIMA modeliu paklaidos, proc.

Table 2.5. Errors of ASETAR and ARIMA models, pct.

\begin{tabular}{|c|c|c|c|c|c|c|}
\hline \multirow{2}{*}{$\begin{array}{l}\text { Suderinto } \\
\text { vartotojų kainu } \\
\text { indekso prekių ir } \\
\text { paslaugų grupe }\end{array}$} & \multicolumn{3}{|c|}{ Adaptuotas SETAR } & \multicolumn{3}{|c|}{ ARIMA } \\
\hline & $\begin{array}{l}\text { Modelio } \\
\text { tipas }\end{array}$ & VSAP & VSKP & $\begin{array}{l}\text { Modelio } \\
\text { tipas }\end{array}$ & VSAP & VSKP \\
\hline $\begin{array}{l}\text { Maistas ir } \\
\text { nealkoholiniai } \\
\text { gėrimai }\end{array}$ & $(2 ; 2 ; 2)$ & 0,0889 & 0,1137 & $\left(\begin{array}{lll}2 & 2 & 0\end{array}\right)$ & 0,2146 & 0,2760 \\
\hline $\begin{array}{l}\text { Alkoholiniai } \\
\text { gèrimai, tabakas }\end{array}$ & $(2 ; 3 ; 3)$ & 0,0343 & 0,0466 & $\left(\begin{array}{lll}0 & 2 & 1\end{array}\right)$ & 0,1911 & 0,3108 \\
\hline $\begin{array}{l}\text { Apranga ir } \\
\text { avalyne }\end{array}$ & $(2 ; 3 ; 3)$ & 0,0456 & 0,0607 & $\left(\begin{array}{lll}1 & 2 & 0\end{array}\right)$ & 0,1663 & 0,2340 \\
\hline $\begin{array}{l}\text { Būstas, vanduo, } \\
\text { elektra, dujos ir } \\
\text { kitas kuras }\end{array}$ & $(2 ; 2 ; 3)$ & 0,1380 & 0,1981 & $\left(\begin{array}{lll}1 & 2 & 0\end{array}\right)$ & 0,4198 & 0,6252 \\
\hline $\begin{array}{l}\text { Būsto apstatymo, } \\
\text { namų ūkio iranga } \\
\text { ir kasdieninè } \\
\text { namų priežiūra }\end{array}$ & $(2 ; 3 ; 3)$ & 0,0264 & 0,0331 & $\left(\begin{array}{lll}0 & 2 & 1\end{array}\right)$ & 0,0804 & 0,1041 \\
\hline Sveikata & $(2 ; 2 ; 2)$ & 0,0501 & 0,0664 & $\left(\begin{array}{lll}1 & 2 & 0\end{array}\right)$ & 0,1309 & 0,1795 \\
\hline Transportas & $(2 ; 2 ; 3)$ & 0,3438 & 0,4271 & $\left(\begin{array}{lll}2 & 2 & 0\end{array}\right)$ & 0,7483 & 0,9328 \\
\hline Ryšiai & $(2 ; 2 ; 2)$ & 0,0900 & 0,1164 & $\left(\begin{array}{lll}2 & 2 & 0\end{array}\right)$ & 0,2197 & 0,2870 \\
\hline Poilsis ir kultūra & $(2 ; 2 ; 2)$ & 0,0596 & 0,0753 & $\left(\begin{array}{lll}1 & 2 & 0\end{array}\right)$ & 0,1327 & 0,1770 \\
\hline Švietimas & $(2 ; 3 ; 2)$ & 0,0830 & 0,1345 & $\left(\begin{array}{lll}1 & 2 & 0\end{array}\right)$ & 0,2848 & 0,4077 \\
\hline $\begin{array}{l}\text { Restoranai ir } \\
\text { viešbučiai }\end{array}$ & $(2 ; 2 ; 3)$ & 0,0715 & 0,0916 & $\left(\begin{array}{lll}0 & 2 & 1\end{array}\right)$ & 0,1757 & 0,2420 \\
\hline $\begin{array}{l}\text { Ivairios prekès ir } \\
\text { paslaugos }\end{array}$ & $(2 ; 3 ; 2)$ & 0,0816 & 0,1053 & $\left(\begin{array}{lll}1 & 2 & 0\end{array}\right)$ & 0,2190 & 0,2942 \\
\hline
\end{tabular}

Rezultatai, pateikti 2.5 lenteleje patvirtina, kad ASETAR modelis ženkliai geriau aprašo nagrinètų laiko eilučių duomenis lyginant su ARIMA modeliu. Geresni modeliavimo rezultatai buvo pasiekti ir laiko eilutems, kurioms nebuvo nustatytas bendrasis netiesiškumas RESET testo pagalba. Tai parodo, kad bendrosios netiesiškumo formos nustatymo testas RESET netinkamas slenkstinio netiesiškumo nustatymui ir gali būti naudojamas tik kaip informacinè priemonè.

Analizuojant adaptuoto SETAR ir ARIMA modelių paklaidas, nustatyta, kad adaptuotas SETAR modelis yra stabilesnis, kadangi paklaidų dispersija ženkliai mažesnè. Modelių paklaidų grafikai pateikti E priede.

Tyrimo rezultatai patvirtino, teigini, kad netiesinès elgsenos, sudètingesnès struktūros ar laiko eilutėms, kurių dispersija reikšmingai kinta laike, modeliavimui tikslinga naudoti adaptuotą SETAR metodą. 


\subsubsection{Ekonominių indikatorių modelio lygčiu sudarymo algoritmas}

Atlikto tyrimo rezultatai, aprašyti 2.3.1-2.3.4 skyreliuose, apsprendè Lietuvos ekonomikos būsenos ir perspektyvos modeliui kurti naudojamų metodų pasirinkimą bei vertinimo algoritmą.

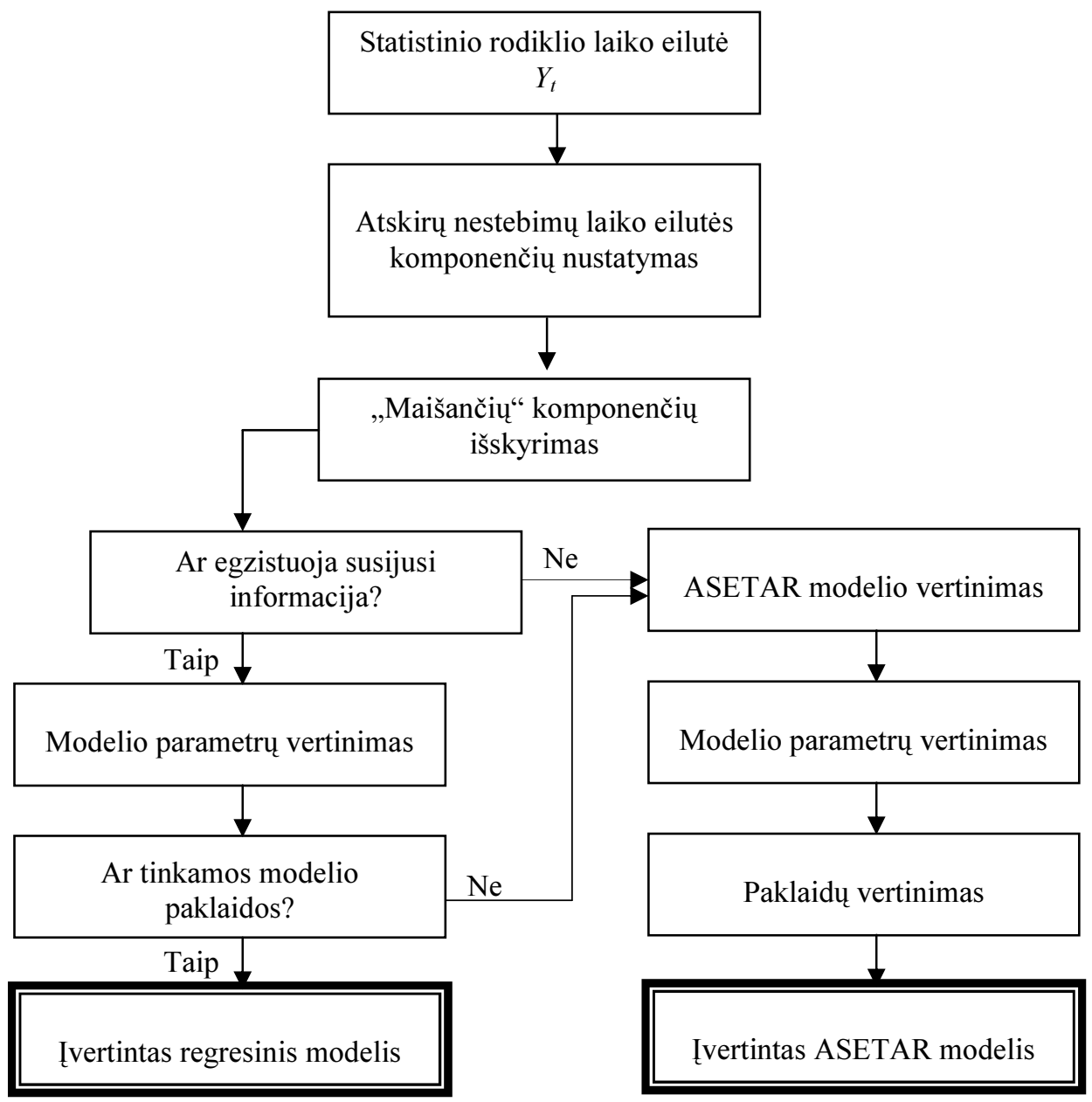

2.11 pav. Modelio lygčių sudarymo algoritmas

Fig. 2.11. Algorithm of model equations construction 
Pirmiausia, naudojant spektrinę analizę, visoms nagrinèjamų ekonominių indikatorių laiko eilutèms buvo nustatytos ir išskirtos nestebimos komponentès. Toliau buvo analizuota ar egzistuoja kiti ekonominiai indikatoriai, kuriu pokyčiais galima pagrịsti nagrinejjamo reiškinio elgseną ekonomine prasme bei irodyti šią priklausomybę naudojant koreliacines matricas. Radus reikšmingus saryšius buvo kuriamos lygtys regresinès analizès metodo pagalba. Jei susijusios informacijos nepavyko rasti arba regresinio modelio paklaidos buvo pakankamai didelès, tuomet buvo sudaromas modelio lygtys, adaptuoto slenkstinio autoregresinio metodu, naudojant 2.3.3 skyrelyje aprašytą algoritmą.

\subsection{Antrojo skyriaus išvados}

1. Ekonominių procesų laiko eilučių, turinčių pastovių ar atsitiktinių svyravimų, adityvių išskirčių, lygio postūmių, praeinančių pokyčių, struktūrinių lūžių, nepastovią dispersiją, modeliai, i̇vertinti tradiciniais ekonometriniais metodais, nèra tinkami naudoti dèl didelių paklaidų ir modelio lygčių parametrų tvarumo problemos.

2. Sparčiai besikeičiančios ekonominès, demografinès, socialinès bei politinès sąlygos reikšmingai įtakoja daugelio šalies ekonominių indikatoriu laiko eilučiu struktūrą, todèl dažniausiai, naudojant ịprastus tiesinius laiko eilučių vertinimo metodus, tokių laiko eilučių modelių paklaidos viršija 10 proc. ir dèl žemo patikimumo negali būti naudojami ekonominiu procesų analizei.

3. Naudojant modeliuotas laiko eilutes, su skirtingais trendo funkcijuc, bei sezoninès komponentès tipais, imituojančiais realias laiko eilutes, nustatyta:

3.1. Prieš ekonominių laiko eilučių modeliavimą endogeniniams ir egzogeniniams modelio kintamiesiems rekomenduojama atlikti ju struktūrinę analizę ir atlikti pirminį laiko eilučiu koregavimą bei išskirti nestebimas komponentes.

3.2. Atlikus modeliuotų laiko eilučiu spektrinę analizę, nustatyta, kad, nepriklausomai nuo laiko eilutès trendo pavidalo, sezoniškumo ar atsitiktinès komponentès svyravimų, spektrinè analizè leidžia tiksliai nustatyti determinuotas nestebimas laiko eilučių komponentes.

3.3. Atlikus laiko eilučių nestebimų komponenčių vertinimo metodų lyginamają analizę, nustatyta, kad tiek parametriniai, tiek neparametriniai metodai pakankamai gerai aprašo nestebimas komponentes: laiko eilutėms, kurių atsitiktinès komponentès 
dispersija nekinta laike tinkamesni parametriniai metodai, kurių dispersija kinta - neparametriniai.

4. Sudètingos prigimties ekonomikos indikatorių laiko eilutėms pasiūlyta nauja modeliavimo metodologija, naudojant laiko eilučių koregavima, dažnuminę analizę bei slenkstinius autoregresinius metodus, kuri leido pagerinti ekonometrinį ekonominių procesų aprašymą.

5. Pasiūlytas netiesinio laiko eilučių vertinimo metodo ASETAR modelio eilès, slenkstinio kintamojo, poslinkio bei modelio lygties parametrų vertinimo algoritmas, susidedantis iš dvidešimties etapų, kuris leido ivertinti sudètingos prigimties laiko eilučiuc, kurioms nepavyksta pritaikyti tradicinių tiesinių metodų, modelio lygtis.

6. Dažniausiai naudojamo bendrosios netiesiškumo formos nustatymo testas RESET nèra tinkamas slenkstinio netiesiškumo aptikimui ir gali būti naudojamas tik kaip informacinè priemonè. Naudojant SETAR tipo modelius laiko eilutès slenkstinio netiesiškumo nustatymui F-kriterijaus testas duota patikimesnius rezultatus.

7. Atlikta modelio paklaidu analizè parodè, kad lyginant su tradiciniais tiesiniais laiko eilučių metodais, sudètingos prigimties ekonominių laiko eilučiu su netiesine elgsena modelio lygtis vertinant ASETAR metodu gaunamos mažesnès, stabilesnès ir su mažesne dispersija paklaidos. 


\section{Šalies ekonomikos indikatoriu dinamikos modelio adekvatumo empirinis tyrimas Lietuvos atveju}

Šiame skyriuje, remiantis ankstesniuose disertacijos skyriuose aprašytais tyrimais bei naudojant pasiūlytą modelio lygčių sudarymo algoritmą, spendžiamas Lietuvos vedančiujų ekonominių indikatorių modelio sudarymo uždavinys. Gauti rezultatai pateikiami pirmiausia išdèstant modelio struktūrą bei modelio lygčiu kintamuju parinkimą sąlygojančius veiksnius, užrašant lygčių specifikacijas, su tikètinais parametrų ženklais, vèliau pateikiamos sudarytos ekonominių indikatorių modelio lygtys su ịvertintais parametrais. Prie kiekvienos ivertintos lygties pateikta apskaičiuota santykinè absoliutinè paklaida, modelio lygčiu adekvatumą parodantis determinacijos koeficientas, liekanų autokoreliaciją matuojanti Durbin-Watson statistika bei modelio lygčių parametrų reikšmingumas. Skyriuje pateiktos ne visos įvertintos lygtys, likusios lygtys pateiktos $\mathrm{F}$ priede.

Skyriaus tematika paskelbtos 7 autorès publikacijos (Bratčikovienè 2005, 2005, 2007, 2007, 2008; Misiūnas, Bratčikovienè 2006, 2007) bei skaityti 7 pranešimai Lietuvos ir tarptautinèse mokslinèse konferencijose. 


\subsection{Modelio struktūra ir formavimo principai}

Analizuojant kitų šalių ekonominio modeliavimo patirti, buvo pastebèta, kad dalis modelių yra kompaktiški, juose dalyvauja tik vedantieji ekonominiai indikatoriai, o tokių modeliu pagrindinis tikslas - operatyviai pateikti patikimą ekonominès būklès vertinimą bei prognozes. Kita dalis modelių, kurie sudaryti iš gausesnio modeliuojamų ekonominių indikatorių kiekio, gali pateikti išsamesnius rezultatus, tačiau dèl didelio ieinančių kintamujų kiekio, šios analizės bei prognozių parengimas užtrunka ženkliai ilgiau. Kuriant disertacijoje teikiamą šalies ekonomikos indikatorių dinamikos modeli, buvo nuspręsta balansuoti tarp pirmojo ir antrojo modeliu tipo. Pagrindinis šio modelio tikslas operatyviai teikti išsamius šalies ekonominès analizès bei prognozavimo rezultatus. Tačiau esant poreikiui, modeli galima nesudètingai plèsti.

Darbe teikiamas modelis apima pagrindinius vedančiuosius šalies ekonomikos indikatorius. Modelis sudarytas iš penkių dalių: gamybos, kainų, prekybos, pajamų, bei užimtumo (3.1 pav.). Sukurtas modelis gali būti taikomas šalies ekonominei būklei tirti ir vertinti, kiekybinei ekonominių indikatorių analizei atlikti, tolesnei ekonomikos perspektyvai prognozuoti.

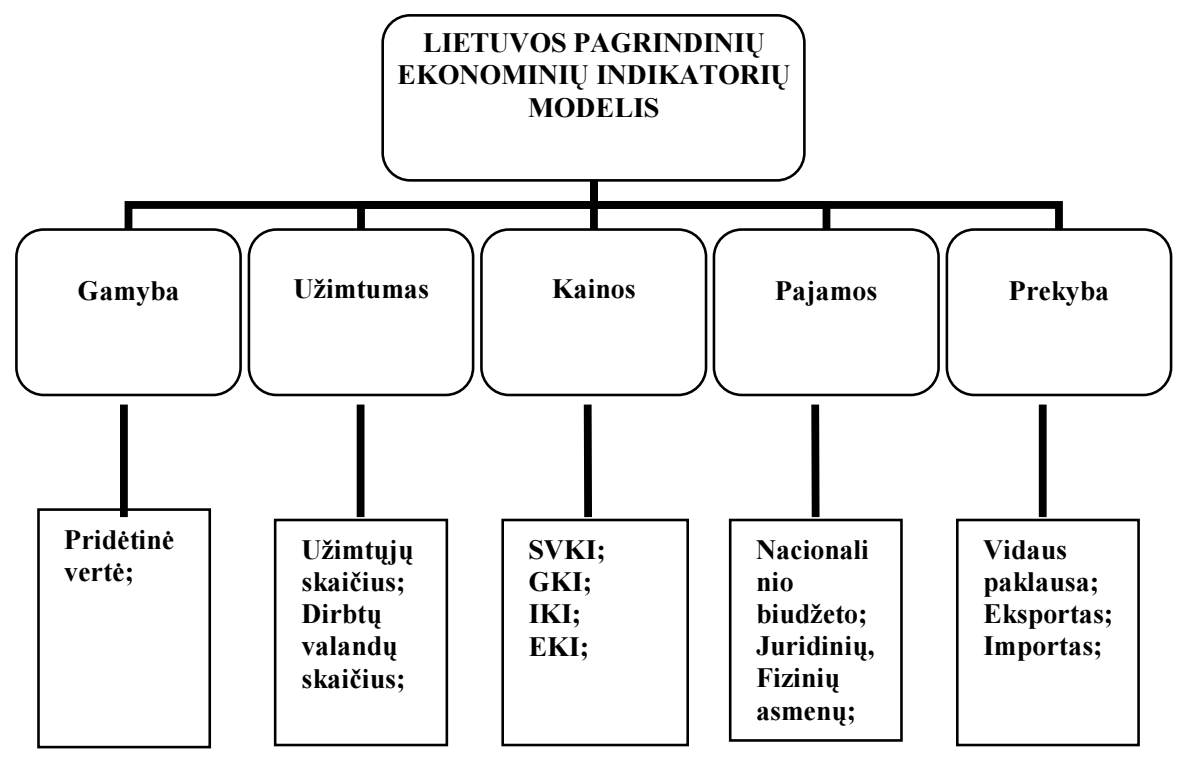

3.1 pav. Pagrindinių Lietuvos ekonominių indikatorių modelio struktūra

Fig. 3.1. Structure of main Lithuanian economic indicators model 
Pagrindiniai modelio endogeniniai kintamieji yra pridètinè vertè, suderintas vartojimo prekių ir paslaugu, gamintojų parduotos pramonès produkcijos, importuojamų bei eksportuojamų prekių kainų indeksai, vidaus prekių paklausa, importas, eksportas, nacionalinio biudžeto, juridinių bei fizinių asmenų pajamos, užimtujų bei dirbtų valandų skaičius.

Sudarant modelio lygtis buvo atsižvelgiama i ekonomini prasminguma, modelio lygčiu paklaidas bei ekonometrini pagristumą. Modelio egzogeniniais kintamaisiais parenkami ekonominiai indikatoriai, turintys ekonomiškai paaiškinamą itaką modeliuojamam endogeniniam kintamajam. Toliau buvo vertinami atrinktų indikatorių koreliacijos koeficientai. Jei egzogeninis kintamasis reikšmingai koreliuoja su endogeniniu, tuomet jis itraukiamas i modeli. Atrinkus visus aiškinamuosius ekonominius indikatorius tikrinama ar jie nèra tarpusavyje priklausomi. Jei egzistuoja multikolinearumo problema, skaičiavimo metu gauti koeficientu ivverčiai bus blogi. Todèl, sprendžiamas egzogeninių rodiklių, kurie užtikrins klasikinès regresijos prielaidų tenkinimą, atrinkimo uždavinys.

Sudètingos prigimties laiko eilutèms ar endogeninių kintamujų, kuriems nepavyko rasti tinkamų aiškinamujų rodiklių ir/ar gauto modelio paklaidos viršija 5 proc., modeliavimui darbe teikiamas naujas adaptuotas slenkstinis autoregresinis metodas, kai prieš modelio sudarymą modeliuojamiems ekonominiams indikatoriams vertinamos nestebimos laiko eilučių komponentès.

\subsubsection{Modelio lygčių formavimo principai ir specifikacija}

Gamyba. Produktų ar paslaugu gamyba, mainai, prekyba bei vartojimas sąlygoja ūkinių subjektų ekonominių interesų atsiradimą. Kiekvieno komercinio subjekto veiklos pagrindinis ekonominis tikslas yra mažiausiomis sąnaudomis patenkinti rinkos poreikius ir to pasèkoje igyti maksimalų finansini ar nefinansini turta.

Gamybos proceso metu kuriamos gèrybès (produktai bei paslaugos), naudojant tam tikrus gamybos išteklius. Yra keletas gamybos veiksnių, nuo kurių priklauso gaminamos produkcijos kiekis - kapitalas, darbas, žaliavos, žemé, energija ir t.t. Visi jie salygoja darbo rinkos arba darbo našumo pokyčius.

Darbo rinkos pokyčiai ivvyksta dèl aktyvių gyventojų pokyčių, kurie ilguoju laikotarpiu atsiranda dèl natūralaus gyventojų prieaugio, o trumpuoju - dèl migracijos. Darbo našumo pokyčius itakoja kapitalas, tenkantis darbo jègai (investicijos i fizini kapitala), darbo kokybès augimas, kurị lemia geresnis išsilavinimas ir geresni darbo igūdžiai (investicijos i darbuotojus) ir techninè pažanga (investicijos i inovacijas). Darbo našumas yra labai svarbus veiksnys ekonomikos augimui skatinti, nesukuriantis neigiamų pasekmių šalies ūkio tvarumui ir kainų stabilumui, todèl siekiant tvarios ekonomikos augimo 
perspektyvos, būtinas ypatingas dèmesys šiam gamybos faktoriui. Gamybos ir paslaugų augimą įtakojantys darbo veiksniai pavaizduoti 3.2 paveiksle.

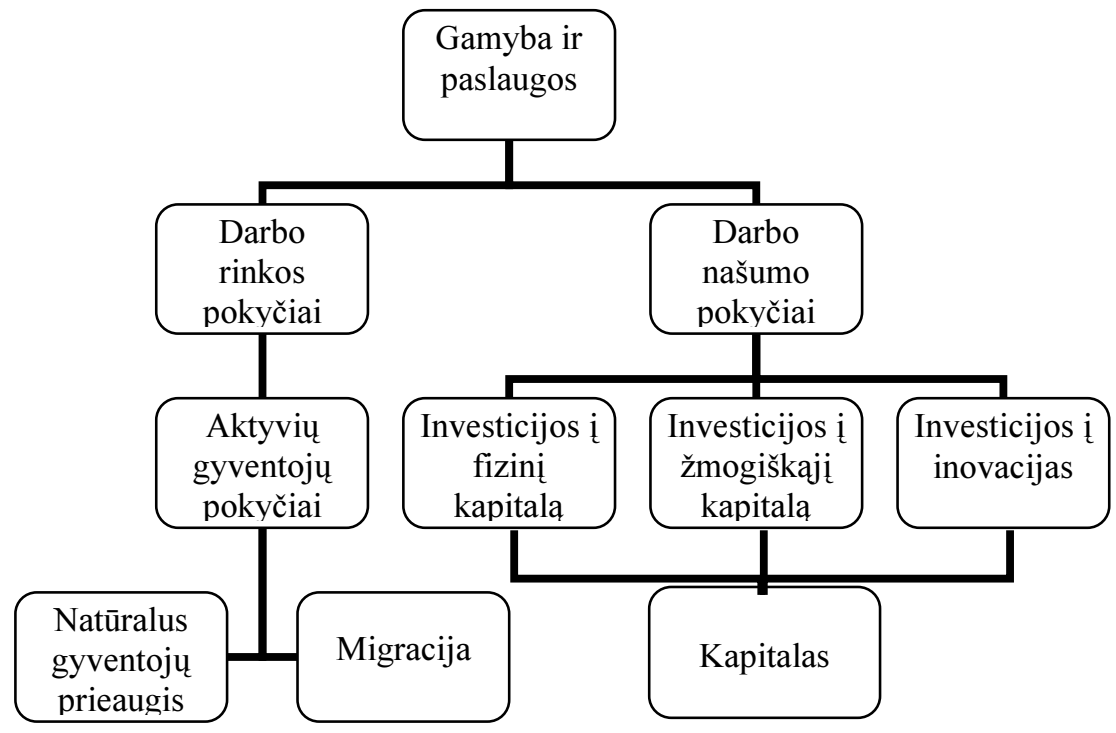

3.2 pav. Gamybos apimti itakojantys darbo veiksniai

Fig. 3.2. Labor input into production process

Norint ivvertinti ir palyginti ivvairių gamybos veiksnių įtaką šalies ekonomikos augimui dažniausiai naudojama gamybos funkcija. Gamybos funkcija parodo ryši tarp pagamintos produkcijos ir sąnaudų t. y. parodo kiek darbo, kapitalo bei kitu gamybos veiksnių ir kokiomis proporcijomis sunaudojama, norint pagaminti tam tikrą produkcijos kieki.

Ekonomineje literatūroje galima rasti keletą gamybos funkcijos modifikacijų. CES (Constant Elasticity of Substitution) funkcija parodo pastovų kapitalo ir darbo pakeičiamumo elastingumą (Arrow ir kt., 1961):

$$
Q(t)=F(t) \cdot\left(\alpha \cdot K^{r}(t)+(1-\alpha) \cdot L^{r}(t)\right)^{\frac{1}{r}} .
$$

Čia $Q(t)$ - produkcija, $F(t)$ - našumas, $K(t)$ - kapitalas, $L(t)$ - darbo veiksnys, $\alpha$-parametras, o $s=\frac{1}{1-r}-$ pakeičiamumo elastingumas.

Bendrasis CES funkcijos pavidalas: 


$$
Q(t)=\left[\sum_{i=1}^{n} \alpha_{i}^{\frac{1}{s}} c_{i}^{\frac{s-1}{s}}\right]^{\frac{s}{s-1}}
$$

Čia $c_{i}$ - naudojami gamybos veiksniai.

Iš CES funkcijos gaunamos ir kitos ekonomikoje naudojamos gamybos funkcijos: Cobb-Douglas funkcija gaunama, kai $\mathrm{s}=1$, tiesinè funkcija gaunama, kai s artèja i begalybę, o Leontief funkcija gaunama, kai s artėja ị 0 .

Kuo daugiau sunaudojama gamybos veiksnių, tuo daugiau prekių ar paslaugų pagaminama ar suteikiama. Tačiau gamybą sąlygojančių veiksnių itaka priklauso nuo analizuojamo laikotarpio ilgio. Ilguoju laikotarpiu yra daugiau galimybių gamybos apimčiai didinti nei trumpuoju, nes per ilgą laiką visi gamybos veiksniai keičiasi, o trumpu laikotarpiu kai kurie veiksniai yra pastovūs arba gali kisti tik labai nežymiai. Ilguoju laikotarpiu gamybos apimtis priklauso ne tik nuo darbo, bet ir nuo kapitalo pokyčių, nes keičiantis gamybos apimčiai, atitinkamai kinta ir investicijos bei taupymas, kurios yra kapitalo sudedamosios dalys. Trumpuoju laikotarpiu kai kurie gamybos veiksniai negali greitai kisti, todèl yra pastovūs. Pavyzdžiui, kapitalas kaupiamas per ilgą laikotarpi ir jo nauda ilgalaikè, o investicijos dažniausiai tik pakeičia nusidèvejjusi kapitalą ar ji papildo. Be to, ribinis kapitalo produktas, kuris apibrežiamas:

$$
\frac{d Q}{d K}=\lim _{\Delta K \rightarrow 0} \frac{\Delta Q}{\Delta K}=\lim _{\Delta K \rightarrow 0} \frac{f(L, K+\Delta K)-f(L, K)}{\Delta K}
$$

ir bet kuriame taške gali būti matuojamas gamybos funkcijos liestinès kampo tangentu tame taške, mažèja didejjant kapitalo kiekiui. Todèl bendrai trumpalaikei apžvalgai kapitalas dažniausiai laikomas pastoviu dydžiu. Tai riboja gamybos apimties pokyčius.

Jei vienas iš gamybos veiksnių reikšmingai nesikeičia, tai gamybos apimtis priklausys nuo kito gamybą sąlygojančio veiksnio - darbo. Kadangi darbo jègos judejjimas rinkoje yra nuolatinis reiškinys, tai ši veiksni galima priskirti prie sparčiai besikeičiančiu gamybos faktoriu. Todèl gamybos pokyčiai trumpuoju laikotarpiu gali ivvykti tik keičiantis darbo veiksniui. Tačiau gamybos apimties augimas didinant darbo sąnaudas turi ribą, kai ribiniai darbuotojo kaštai viršija naudą. Tuomet didinti darbo veiksni tampa nebenaudinga. Todèl neįmanoma vien tik didinant darbo sąnaudas tiketis nuolatinio ir pastovaus gamybos augimo.

Šiame darbe, modeliuojant atskirų gamybos veiklų pridėtinę vertę, remiamasi bendruoju gamybos funkcijos atveju:

$$
Y(t)=A \cdot F\left(x_{1}(t), x_{2}(t), \ldots, x_{m}(t)\right) .
$$


Čia $Y(t)$ - pridètinè verte, $x_{1}(t), x_{2}(t), \ldots, x_{m}(t)$ - faktoriai, itakojantys gamybos procesa, o $A$ - bendrasis gamybos veiksnių našumas.

Gamybos funkcijos vertinamos laikantis prielaidų:

- didinant vieno kurio nors veiksnio sąnaudas, kai kitos sąnaudos pastovios, pasiekiamas ribinis gamybos apimties augimas;

- egzistuoja naudojamų gamybos veiksnių pakeičiamumo ir papildymo, nepakeitus gamybos apimties, galimybè.

Disertacinio darbo pagrindinis tikslas yra atlikti trumpalaikę ir vidutinio laikotarpio šalies ūkio analizę, todèl ịvertintose lygtyse didesnis dèmesys buvo skirtas darbo faktoriams: faktiškai dirbtų valandų bei užimtujų skaičiui. Naudojantis koreliacinès analizès rezultatais, darbo indikatorium atrinktas arba užimtujjų skaičius arba vidutinis mènesinis dirbtų valandų skaičius.

Kadangi Lietuvoje nèra ivertintu ir oficialiai paskelbtų bendrojo kapitalo pagal ekonominès veiklos rūšis laiko eilučiuc, tai, aprašant gamybos indikatorius, naudota modifikuota gamybos funkcija, kur vietoj kapitalo itraukiami jo pokyčius ịtakojantys kintamieji - materialinès investicijos pagal paskirti ir/ar tiesioginès užsienio investicijos. Kai kuriose lygtyse papildomai itrauktas nuosavas kapitalas bei prekių ir paslaugų pardavimų pokyčiai.

Analizuojant šalies ūkio realias laiko eilutes, darbe naudotos ivvairios gamybos funkcijos modifikacijos. Siekiant gauti kuo tikslesnius ir patikimesnius rezultatus, buvo sudarytos tiek adityvios, tiek ir multiplikatyvios gamybos funkcijos modelių lygtys. İvertinus gamybos funkciją atskirose šalies ūkio veiklose, analizuoti šalies ekonominius pokyčius nulèmę faktoriai.

Gamybos bloke modeliuojama bendroji pridètinè vertè pagal 21 ekonominę veiklos rūši. Pridètinès vertès lygčių specifikacija:

$$
Y=f_{Y}\left(\begin{array}{c}
L, I, X_{7}, X_{5} \\
++
\end{array}\right) .
$$

Čia $Y$ - pridètinè verte, $L$ - darbas, $I$ - investicijos, $X_{7}$ - nuosavas kapitalas, $X_{5}-$ prekių ir paslaugų pardavimo pajamos.

Užimtumas. Kadangi vienas iš pagrindinių veiksnių formuojančių gamybą trumpuoju laikotarpiu yra darbas, o jis tiesiogiai priklauso nuo darbingų asmenų skaičiaus ir jų motyvacijos aktyviai dalyvauti darbo rinkoje, tai pirmiausia buvo nuspręsta atlikti darbo pasiūlos bei paklausos analizę Lietuvoje.

Spręsdamos, kiek darbuotojų samdyti, imonès maksimizuoja pelną, kuris lygus pagamintos produkcijos ar suteiktu paslaugų vertei atemus sąnaudas. Tam kad apskaičiuoti pelną maksimizuojantị darbo kieki, i̇monès palygina papildomo darbuotojo samdymo naudą ir kaštus. Kaštai yra sąnaudos darbuotojo darbo užmokesčiui, o nauda - papildomo darbuotojo pagamintos produkcijos vertè. Jei 
nauda didesnè už kaštus, papildomas darbuotojas padidins įmonès pelną. Tokiu atveju įmonei naudinga samdyti papildomus darbuotojus.

Analizuojant darbo paklausą galima naudoti imonių pelną (Heijdra J., Ploeg F., 2002). Galima naudoti tiek grynaji pelną, tiek pelną prieš apmokestinimą ar bendraji pelna, kuris lygus pardavimo pajamoms atemus pardavimo savikainą. Norint išvengti neapskaitytos ekonomikos itakos, vietoj pelno tikslingiau naudoti pridètinę vertę to meto kainomis, kuri lygi sukurtos produkcijos ir tarpinio vartojimo skirtumui. Todèl šiame darbe darbo paklausa analizuojama naudojant pridètinę vertę:

$$
\Pi(t) \equiv P(t) Q(t)-W(t) X_{1}(t),
$$

Čia $\prod(t)$ - darbo paklausa, laiko momentu $t, P(t)$ - parduodamų prekių ar paslaugų kainos, $Q(t)$ - produkcija, $W(t)$ - nominalus darbo užmokestis, $X_{1}(t)$ užimtujjų skaičius.

Norint apskaičiuoti maksimalų pelną, didinant darbuotojų skaičių, reikia ivertinti:

$$
\max _{\left\{X_{1}(t)\right\}} \Pi(t) \equiv P(t) F\left(X_{1}(t), K(t)\right)-W(t) X_{1}(t) .
$$

Maksimalus pelnas apskaičiuojamas diferencijuojant:

$$
\frac{d \Pi(t)}{d X_{1}(t)}=0 \Rightarrow P(t) F_{X_{1}(t)}^{\prime}\left(X_{1}(t), K(t)\right)-W(t)=0 .
$$

O maksimumo taškas randamas diferencijuojant antrą kartą.

Papildomus darbuotojus tikslinga samdyti tol, kol ribinè darbuotojo nauda neviršys ribinių kaštų. Laikant, kad kapitalas trumpuoju laikotarpiu nekinta ir darant prielaida, kad visuminès gamybos funkcija yra teorinè Cobb-Douglas funkcija, nesudètinga šią situaciją pavaizduoti grafiškai. Didinant darbuotojų skaičių, pagaminama produkcija didèja netolygiai. Todèl yra ribinis darbuotojų skaičius, su kuriuo pasiekiamas maksimalus pelnas (3.3 pav.).

Darbuotoju paklausa gali būti išreikšta funkcija, priklausančia nuo darbo užmokesčio, gamintojų kainų ir kapitalo, todèl, pažymèjus ją $\widetilde{X}$, galime užrašyti $\widetilde{X}=\tilde{X}(\mathrm{~W} / \mathrm{P}, \mathrm{K})$. Trumpuoju laikotarpiu darbuotojų paklausa turi priklausyti tik nuo darbo užmokesčio ir gamintojų kainų. Be to, didesni darbo kaštai sąlygoja aukštesni ribini darbo našumą ir mažesnę darbuotojų paklausą (Heidra, Ploeg, 2002).

Visuminę paklausą darbui itakoja tie patys veiksniai kaip ir atskiros imonès atveju, todèl šią teoriją galima taikyti ne tik vienos imonès atveju, bet ir makroekonominejje analizeje, kuriant darbuotoju paklausos modelius atskiroms veiklos rūšims. 


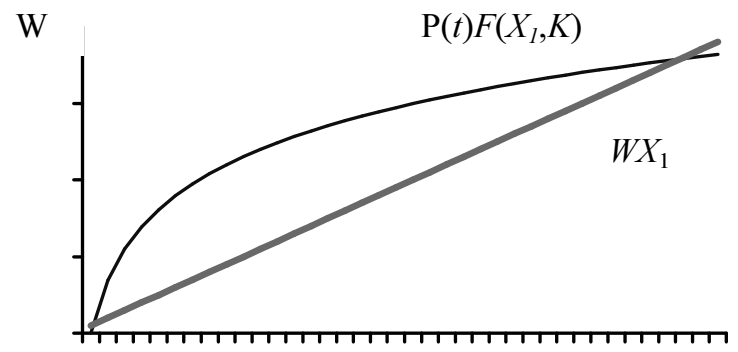

$X_{1}$

3.3 pav. Ribinė darbuotojų nauda

Fig. 3.3. Marginal benefit of workers

Analizuojant darbuotojų paklausą, būtina kartu analizuoti ir darbuotojų pasiūlą.

Jei imonès pačios gali nustatyti produkcijos kainas ir darbuotojų darbo užmokesčius ir taip kontroliuoti savo sąnaudas bei pajamas, tai visiškai kitokia situacija yra su namų ūkiais. Nors jie formuoja darbo rinkos pasiūlą bei visuminę prekių ir paslaugų paklausa, tačiau negali tiksliai žinoti, kiek galès isigyti prekių ir paslaugų už gaunamą atlyginimą. Namų ūkiai gali tik apytiksliai ivertinti jų vartojimo galią.

Darbingo amžiaus asmenys, ivertindami darbo naudą ir darbo kaštus, formuoja darbo pasiūlą. Pagrindinè darbo nauda yra prekių ir paslaugų vartojimo galimybė už uždirbtas pajamas, o darbo kaštai - laisvalaikio praradimas.

Darbo pasiūla analizuojama naudojant naudingumo funkciją:

$$
L S(t) \equiv \operatorname{LS}\left(P C(t), 1-X_{2}(t)\right) .
$$

Čia $L S(t)$ - darbo pasiūla, laiko momentu t, $P C(t)$ - privatus vartojimas, $X_{2}(t)-$ faktiškai dirbtų valandų skaičius.

Kaip ir darbo paklausos atveju, norint rasti optimalų darbo pasiūlos taška, reikia maksimizuoti funkciją $L S(t)$ su salyga, kad $P C(t)=\frac{W(t)}{P^{e}(t)} X_{2}(t)$, t. y. reikia rasti:

$$
\max _{\left\{\hat{X}_{2}(t)\right\}} L S(t) \equiv L S\left(\frac{W(t)}{P^{e}(t)} X_{2}(t), 1-X_{2}(t)\right) .
$$

Čia $P^{e}(t)$ - tikètinas vartojimo prekių ir paslaugų kainų pokytis, laiko momentu $t$. 
Visumini darbo pasiūlos padidejjimą gali formuoti tik labai nedaug veiksnių: realaus darbo užmokesčio augimas, darbingo amžiaus gyventojų padidejjimas, neaktyvių gyventojų sumažejimas.

Šiame darbe darbo pasiūla ir paklausa vertinama sudarant faktiškai dirbtų valandų ir užimtujų skaičiu lygtis atskirose ekonominès veiklos rūšyse. Žemiau pateikta darbo pasiūlos ir paklausos lygčių specifikacija.

$$
\Pi=f_{\Pi}\left(\begin{array}{c}
P_{G}, Y_{+}, W, X_{+} \\
+
\end{array}\right) .
$$

Čia $\prod$ - darbo paklausa, $P_{G}-$ gamintojų Lietuvos rinkoje parduotos produkcijos kainų indeksai, $Y$ - pridètinè vertè, $W$ - vidutinis mènesinis bruto darbo užmokestis, $X_{1}-$ užimtujų skaičius.

$$
L S=f_{U}\left(\begin{array}{c}
P C, X_{2} \\
+-
\end{array}\right) .
$$

Čia $L S$ - darbo pasiūla, $P C$ - prekių ir paslaugų vartojimas, $X_{2}-$ faktiškai dirbtų valandų skaičius.

Kainos. Gamybos kaštai susidaro bet kuriame versle: žemès ūkyje, išgaunamojoje ir apdirbamojoje gamyboje, paslaugų srityje. Juos sudaro visų panaudotu gamybinių išteklių (darbo, kapitalo, ir kt.) vertè. Siekiant ekonominio efektyvumo, gamintojams būtina įvertinti išlaidas, naudojamiems gamybos veiksniams. Jei keičiasi gamybos veiksnių kainos, tai gamybos išlaidos taip pat pasikeičia. Tuomet gamintojui tenka iš naujo spręsti naudojamų gamybos veiksnių optimizavimo uždavini arba peržiūrèti savo gaminamos produkcijos ar teikiamų paslaugų kainas. Dideli kainų svyravimai apsunkina santykini prekių ir paslaugų kainu pokyčių vertinimą, veda prie nukrypimų nuo efektyvaus resursų paskirstymo, dèl šių svyravimų vyksta turto ir pajamų perskirstymas, didejja investavimo rizika.

Vienas iš svarbiausių gamybos veiksnių trumpuoju laikotarpiu yra darbas. Darbo apmokejjimas sudaro gana didelę gamintojų kaštų dalị. Gaminama produkcija, užimtumas, darbo užmokestis ir kainos yra tiesiogiai susijusiame cikliniame ryšyje. Norint gaminti daugiau produkcijos reikia daugiau darbuotojų todèl atsiranda daugiau užimtujų. Didèjant užimtujjų skaičiui mažèja nedarbo lygis. Žemas nedarbo lygis sąlygoja darbo užmokesčio kilimą. Darbo užmokesčio didejimas didina gamintojų kaštus, todèl gamintojai kelia produkcijos ar paslaugų kainas. Pabrangus gamintojų parduodamoms prekèms ar paslaugoms, bei išaugus vartotojų kainoms, krenta darbo nauda, todèl darbdaviai, noredami išlaikyti darbuotojus, yra priversti didinti darbo užmokestį. 
Nors darbas sudaro didelę gamybos kaštų dalị, tačiau būtina atsižvelgti ir ị kitus gamintojų patiriamus kaštus. Norint atlikti išsamią analizę, sudaroma gamintojų patiriamų kaštų funkcija, kuri ivvertinama naudojant gamybos funkciją papildytą išteklių kainų pokyčiais:

$$
Z(t)=\hat{A} \cdot F\left(Z_{1}(t) \cdot P_{1}(t), Z_{2}(t) \cdot P_{2}(t), \ldots, Z_{m}(t) \cdot P_{m}(t)\right) .
$$

Čia $Z(t)$ - bendrieji gamybos kaštai, $\mathrm{P}_{1}(t), P_{2}(t) \ldots P_{m}(t)$ - gamybos išteklių kainų indeksai, $\hat{A}$ - parametras.

Be gamintojų patiriamų kaštų, sprendimą dèl produkcijos kainų ịtakoja rinka - namų ūkių ir valdžios sektoriaus galutinis vartojimas, bei parduodamos produkcijos kiekis, investicijos, bei eksportas. Todèl vertinant gamintojų kainas i kaštų funkciją įtraukiami anksčiau minèti regresoriai.

$$
\begin{gathered}
P_{G}(t)=\hat{A} \cdot F\left(Z_{1}(t) \cdot P_{1}(t), Z_{2}(t) \cdot P_{2}(t), \ldots, Z_{m}(t) \cdot P_{m}(t), V_{n}(t, v), V_{v}(t, v), I(t, v),\right. \\
\left.X_{8}(t, v), e(t, v)\right) .
\end{gathered}
$$

Čia $P_{G}(t)$ - gamintojų kainų indeksai, $V_{v}(t)$ - valdžios sektoriaus vartojimo išlaidos, $I(t)$ - investicijos, $X_{8}(t)$ - parduota produkcija, $e(t)$ - eksportuota produkcija, $v$ - laiko postūmis, $v=0,1,2,3,4$.

Pagrindinis gamintojų tikslas yra gauti maksimalu pelną todèl gamintojų kainų pokyčiai turi būti aukštesni už ribinių kaštų pokyčius, t. y. $\hat{A}=1+\mu$. Simboliu $\mu$ čia pažymèta gamintojų marža.

Nors galutinio vartojimo prekių ir paslaugų kainų pokyčius labai itakoja gamintoju parduodamu prekių ir paslaugu kainų svyravimai, tačiau jie nèra tapatūs. Taip yra dèl dviejų priežasčių. Pirmiausia, dalis gamintojų parduodamų prekių nèra skiriama galutiniam, o tarpiniam vartojimui arba eksportui. Antra, vartotojai perka ne tik vietos gamintoju pagamintas prekes ar paslaugas, bet ir importuotas.

$$
\begin{gathered}
P_{V j}(t)=(1+\eta) \cdot\left[( 1 + \mu ) \cdot F \left(Z_{l}(t) \cdot P_{1}(t), Z_{2}(t) \cdot P_{2}(t), \ldots, Z_{m}(t) \cdot P_{m}(t), V_{n}(t, v),\right.\right. \\
\left.\left.V_{v}(t, v), I(t, v), X_{8}(t, v), e(t, v)\right) \cdot \Phi\left(P_{i m j}(t, v)\right)\right] .
\end{gathered}
$$

Čia $P_{V j}(t)-j$-tosios prekès, prekių grupès ar paslaugos vartotojų kainų indeksas, $\eta$ - mažmenininkų marža, $P_{i m j}(t)-j$-tosios importuojamos prekès, prekių grupès ar paslaugų kainų indeksas.

Infliacija susidaro tada, kai visuminè paklausa viršija visuminę pasiūlą. Ilguoju laikotarpiu pagrindinis veiksnys, veikiantis visuminę paklausa, yra pinigų kiekis. Todèl $\mathfrak{i}$ galutinę vartojimo prekių ir paslaugų kainų lygtị buvo itrauki papildomi regresoriai, kurie atspindi vartotojų perkamają galią. Vienas iš tokių indikatorių yra darbo užmokestis. Tačiau dèl pastaraisiais metais 
sustiprejjusių emigracinių procesų ir išaugusių darbo pajamų iš užsienio, darbo užmokestis nepilnai atspindi Lietuvos vartotojų perkamają galią. Todèl, patikrinus reikšmingumą, i modelio lygtis buvo įtrauktas darbo pajamų kreditas, bei pinigų kiekis.

Vartojimo prekių ir paslaugu kainų modelių lygtys sudarytos dvylikai skirtingu grupių, kurios suklasifikuotos pagal Ekonominio bendradarbiavimo ir plètros organizacijos parengtą tarptautinį Individualaus vartojimo išlaidų pagal paskirti klasifikatorių (COICOP - Classification of Individual Consumption by Purpose).

Ivertinti indeksai agreguojami naudojant Laspeireso formulę pagal Statistikos departamento parengtą ir kasmet atnaujinamą svorių sistemą:

$$
P_{V}(t)=\sum_{i=1}^{12} w_{i} \cdot P_{V i}
$$

Čia $w_{i}-i$-tosios prekès, prekiu grupès ar paslaugos svoris vartojimo prekių ir paslaugų krepšelyje.

Kainų stabilumas - geriausias pinigu politikos irankis, kuriuo galima prisidèti prie kitų dviejų svarbių ekonominès perspektyvos tikslų - ekonominio augimo ir darbo vietu kūrimo. Lietuvoje per paskutiniuosius 10 metu buvo registruojami ir defliacijos, ir aukštos infliacijos periodai, kurie neigiamai itakojo šalies ekonomini stabilumą. Darbe analizuotos įvairių veiksnių sąsajos su infliacijos pokyčiais Lietuvoje.

Trumpu laikotarpiu infliaciją nulemiančius veiksnius galima suskirstyti i paklausos ir sąnaudų grupes. Todèl kainų analizei i ekonominių indikatorių modeli integruota sąnaudu - produkcijos lentelè. Lenteleje parodoma, prekiu ir paslaugu vartojimas (pagal ekonominès veiklos rūšis), galutinis vartojimas, bendrasis kapitalo formavimas ir eksportas. Pasinaudojant šiais duomenimis sudarytas programinis modulis, kurio pagalba apskaičiuojamas išteklių kainų pokyčiu poveikis galutinio vartojimo kainoms, nustatomi vartojimo prekių ir paslaugų pokyčiai, pasikeitus konkrečių išteklių kainoms:

$$
Y(\cdot)=\sum_{k=1}^{n} \sum_{i} \frac{Z_{i j}}{\sum_{j} Z_{i j}} P_{i} w_{k} .
$$

Čia $Z_{i j}$-j-tosios veiklos sąnaudos $i$-tojoje veikloje, $P_{i}$ - sąnaudų $i$-tojoje veikloje kainų indeksas, $w_{k}-$ svoris.

Toliau pateikiamos kainų indeksų specifikacijos.

$$
P_{G}=f_{P_{G}}\left(\begin{array}{c}
L \cdot W, I_{+}, X_{7}, V_{n}, V_{v}, X_{8}, P_{+}^{P_{+}}, \underset{+}{E X} \\
++.
\end{array}\right) .
$$


Čia $P_{G}$ - gamintojų Lietuvos rinkoje parduodamos pramonès produkcijos kainų indeksai, $L$ - darbas, $W$ - vidutinis ménesinis bruto darbo užmokestis, $I-$ investicijos, $X_{7}$ - nuosavas kapitalas, $V_{n}$ - namų ūkių vartojimo išlaidos, $V_{v}-$ valdžios sektoriaus vartojimo išlaidos, $X_{8}$ - parduota produkcija, $P_{\exp }-$ eksporto kainų indeksas, $E X$ - eksportuota produkcija.

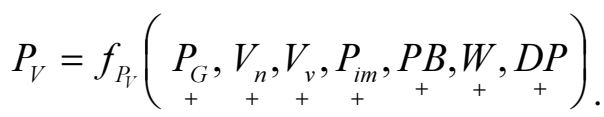

Čia $P_{V}$ - suderinti vartotojų kainų indeksai, $P_{G}-$ gamintojų Lietuvos rinkoje parduotos produkcijos kainų indeksai, $V_{n}$ - namų ūkių vartojimo išlaidos, $V_{v}-$ valdžios sektoriaus vartojimo išlaidos, $P_{i m}$ - importo kainų indeksai, $P B(t)-$ pinigų bazè: grynieji pinigai apyvartoje, kredito istaigų einamosios sąskaitos ir privalomosios atsargos, $W$ - vidutinis mènesinis bruto darbo užmokestis, $D P(t)$ darbo pajamų kreditas.

Pajamos. Bet kurio subjekto pajamoms būdingos dvi pagrindines funkcijos: vartojimo (einamuju poreikių tenkinimas) ir kaupimo (dabartinio vartojimo atidejjimas i kitus laikotarpius, ateities poreikių tenkinimui). Pajamos gali būti tiek piniginès formos, tiek natūrinių išteklių pavidalu. Šiame darbe modeliuojamos pajamos skirstomos i gyventojų, ūkio subjektų ir nacionalinio biudžeto pajamas. Toliau trumpai aptarsime kiekvienos grupès pajamų šaltinius, pajamų srautus bei esamus Lietuvos pajamų indikatorius.

Noredami užtikrinti pakankamą savo gyvenimo gerovę, gyventojai naudoja turimus išteklius: žmogiškaji kapitalą, fizini bei finansini turtą. Kiekvienas šių išteklių teikia jų savininkui atitinkamas pajamas. Paprastai individo gaunamos pajamos yra tiesiogiai susijusios su jo veiklos pobūdžiu.

Gyventojų pajamų šaltinius galima suskirstyti pagal pajamų prigimti $i$ tris grupes: rinkos, perskirstymo sistemos arba kitų asmenų paramos. Pajamos yra priskiriamos rinkos pajamoms, jei yra gaunamos vienoje iš rinku - darbo, finansu ar turto rinkoje. Perskirstymas susijęs su tam tikrais valstybès isipareigojimais ir apima gyventoju pajamas, gaunamas iš socialinès apsaugos sistemos plačiaja prasme bei natūrinius valstybès transferus. Šios srities pajamas namų ūkio nariai gali gauti ir nenaudodami jokio kapitalo, tiesiog turi atlikti tam tikrus reikalavimus arba patekti į tam tikrą gyventojų kategoriją. Kitų asmenų paramą galima taip pat priskirti perskirstymui, tačiau ji nèra susijusi su valstybės isipareigojimais. Tai laisvanoriška šeimos narių, giminių, nevyriausybinių organizacijų parama. Statistiniai duomenys rodo, kad kitų namų ūkių parama nèra reikšminga, todèl šiame darbe jie nemodeliuojami.

Namų ūkių disponuojamos pajamos atspindi namų ūkio vartojimo galimybes, parodo šalies socialinį ekonomini išsivystymą. Pajamų srautai 
informuoja apie gyventojų ekonominị aktyvumą, išteklių pasiskirstymą, šalies ūkio struktūrą.

Informaciją apie namų ūkio disponuojamąsias pajamas rengia Lietuvos Statistikos departamentas, atlikdamas metini pajamų ir gyvenimo sąlygu statistini tyrimą. Tyrimo rezultatai rodo, kad namų ūkių disponuojamos pajamos mažeja jau keletą metų iš eilès. Be to, analizuojant namų ūkių pasiskirstymą pagal pagrindini pajamų šaltini, pastebèta, kad namų ūkių, kurių pagrindinis pajamų šaltinis buvo samdomo darbo pajamos, kiekis pastaraisiais metais taip pat santykinai sumažèjo. Gyventojų, kurių pagrindinis pajamų šaltinis socialinès išmokos, skaičius stabiliai augo. Paskutinio atlikto pajamų ir gyvenimo sąlygu tyrimo rezultatai rodo, kad 2011 metais iš samdomo darbo pajamų gyveno 51 proc. visų namų ūkių, savarankiškai dirbantys asmenys sudare 4 proc., tuo tarpu iš socialinių išmokų gyveno 42 proc. namų ūkių (iš jų socialinès išmokos senatvejje sudare 29 proc., o kitos socialinès išmokos - 13), likusios pajamos (2 proc.) buvo gautos iš kitų pajamų šaltinių.

Skelbiamos tik metinès namų ūkių pajamos, o šiame darbe naudojamos ketvirtinio dažnumo laiko eilutės, tai gyventojų pajamų pokyčiams aprašyti buvo parinkti kiti ekonominiai indikatoriai tiesiogiai susiję su pajamomis. Daugiau nei pusé namų ūkių gyvena iš samdomo darbo pajamų, o darbo užmokestis geriausiai atspindi samdomo darbo pajamas, todèl ši ekonominį indikatorių buvo nuspręsta itraukti i modelị. Namų ūkių, kurių pagrindinis pajamų šaltinis yra socialinès išmokos, didžiają dali sudaro pensijų gavejjai, todèl buvo sudaryta ir socialinio draudimo vidutinès senatvès pensijos lygtis. Kitų ketvirtinių duomenu̧, kurie atspindètų privačių asmenų pajamas Lietuvoje rasti nepavyko.

Rašant apie užimtumą aptarème, kad dirbantieji vertina darbo naudą pagal prekių ar paslaugų vartojimo galimybes, t. y. pagal tai, kiek galès už savo uždarbị ịsigyti prekių bei paslaugų $\left(\mathrm{W} / \mathrm{P}^{\mathrm{e}}\right)$. Darbdaviai darbo užmokestị dažnai sieja su esama situacija darbo rinkoje, kurią atspindi nedarbo lygis. Todèl sudarant darbo užmokesčio lygtị ịtraukiamas tikètino kainų lygio faktorius, bei nedarbo lygis:

$$
W(t)=P^{e}(t) F(U n(t), z(t)) .
$$

Čia $W(t)$ - vidutinis mènesinis bruto darbo užmokestis, $P^{e}(t)$ - laukiamas kainų lygis, $U n(t)$ - nedarbo lygis, $z(t)$ - kiti faktoriai, itakojantys darbo užmokestį.

Modelio lygtyse, tikètino kainu lygio nustatymui naudotas praejusio laikotarpio vartotojų kainų indeksas.

Patikimu regresorių vidutinès valstybinio socialinio draudimo senatvès pensijos modeliavimui nepavyko rasti, todèl šis indikatorius modeliuojamas naudojant adaptuotą SETAR. 
Ūkio subjektų vadovai bei darbuotojai nuolat sprendžia labai įvairius imonès veiklos klausimus, pvz., kiek reikia isigyti paslaugu ir prekių, kad nesutriktų imonès darbas, bet nebūtų ǐšaldytos apyvartinès lěšos, kiek ir už kokią kainą parduoti (pagamintas) prekes ar paslaugas, kad gautų kuo didesnes pajamas ir galètų pasiekti kuo didesni pelna, kiek darbuotojų reikia pasamdyti, kad būtų ivykdyti visi turimi užsakymai, kaip sumažinti sąnaudas ir pan. Norint igyvendinti pagrindinius įmonès keliamus tikslus, ūkio subjektams tenka nuolat stebèti ekonominius pokyčius ir tendencijas ne tik imonès viduje, bet ir savo bei užsienio šalyse. Visų šių klausimų sprendimai įtakoja tiek ūkio subjektų situaciją kiekvienu laiko momentu, tiek ir juc veiklos rezultatą - pajamas. 3.4. paveiksle pavaizduota bendro pobūdžio supaprastinta ūkio subjektų veiklos schema.

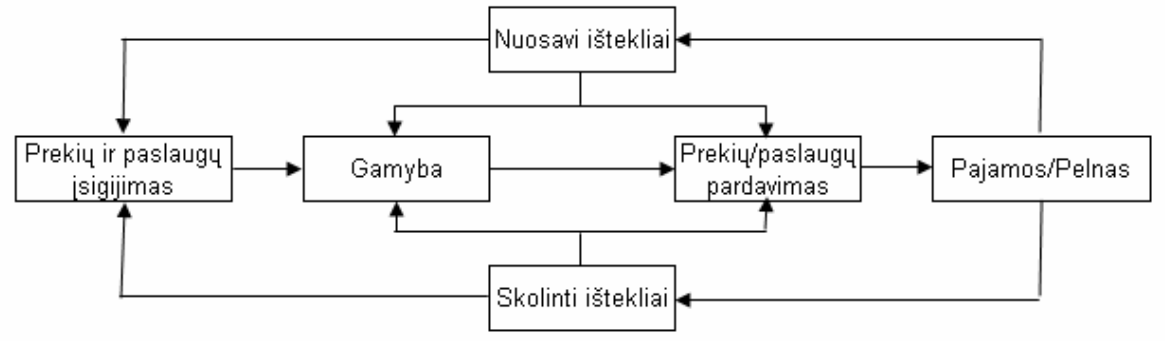

3.4 pav. Supaprastinta ūkio subjektu veiklos schema

Fig. 3.4. Simplified scheme of activities of enterprises

Kadangi ne visoms i̇monèms būdinga gamybos fazè, tai ją pašalinus, schema atspindi prekybos ar paslaugų i̇monès veiklą.

Lietuvos Statistikos departamentas renka, sistemina bei apdoroja imoniu finansinius duomenis. Šiame skyrelyje modelio lygtis buvo sudaryta imonių pardavimų ir kitos veiklos pajamų sumai.

Nacionalinio biudžeto pajamos apskaičiuojamos pagal TVF valstybès finansų statistikos vadovą (GFSM, 2001). Valdžios sektorių Lietuvoje sudaro du subsektoriai: centrinè valdžia ir vietinè valdžia. Centrinè valdžia apima valstybės biudžetą, socialinès apsaugos fondus („Sodra“ ir Privalomojo sveikatos draudimo fondo biudžetas, Užimtumo fondas) ir nebiudžetinius fondus. Nebiudžetinių fondų skaičius mažejja ir šiuo metu jų yra tik 5: Privatizavimo fondas, Garantinis fondas, 1990 metų blokados fondas, Ignalinos atominès elektrinès eksploatavimo nutraukimo fondas, Rezervinis (stabilizavimo) fondas. Vietinè valdžia apima savivaldybių biudžetus.

Nacionalinis Lietuvos biudžetas sudaromas iš valstybès ir savivaldybių biudžetų. Jis susideda iš mokesčių, kitų pajamų bei Europos Sajungos paramos. 


$$
B(t)=\sum_{i} B_{i}^{m}(t)+\sum_{l} B_{l}^{k}(t)+B^{p}(t) .
$$

Čia $B(t)$ - nacionalinio biudžeto pajamos, $\sum_{i} B_{i}^{m}(t)$ - mokestinių pajamų suma, $\sum_{l} B_{l}^{k}(t)$ - kitų pajamų suma, $B^{p}(t)$ - Europos Sajungos parama.

Gyventojų pajamų mokesčiui aprašyti naudojamas užimtujų skaičius ir vidutinis mėnesinis bruto darbo užmokestis. Pelno ir socialinių mokesčių pokyčių ivertinimui itraukiamas bendrasis imonių pelnas, prekių ir paslaugu mokesčiams - sukurta pridètinè verté ir importas. Sudaryta visų mokestinių pajamų modelio lygtis:

$$
B^{m}(t)=F\left(X_{1}(t), W(t), \bar{X}(t-1), Y(t), I M(t)\right) .
$$

Čia $X_{1}(t)$ - užimtujų skaičius, $W(t)$ - vidutinis mėnesinis bruto darbo užmokestis, $\bar{X}(t-1)$ - praejjusio laikotarpio įmonių ūkinès veiklos pelnas, $I M(t)$ - importas.

Kitos nacionalinio biudžeto pajamos ir Europos Sajungos paramos laiko eilutès modeliuojamos disertacijoje teikiamo - adaptuoto slenkstinio autoregresinio modelio pagalba.

Toliau pateikiamos pajamų indikatorių lygčių specifikacijos.

$$
W=f_{W}\left(\begin{array}{c}
P_{V}, U_{+} \\
+
\end{array}\right) .
$$

Čia $W$ - vidutinis mėnesinis bruto darbo užmokestis, $P_{V}-$ suderintas vartotojų kainu indeksas, $U n$ - nedarbo lygis.

$$
X_{5}=f_{X_{5}}\left(\begin{array}{c}
Y, P_{G} \\
+
\end{array}\right) .
$$

Čia $X_{5}$ - pardavimo pajamos, $Y$ - sukurta pridètinè verte, $P_{G}$ - gamintoju Lietuvos rinkoje parduodamos pramonès produkcijos kainų indeksai.

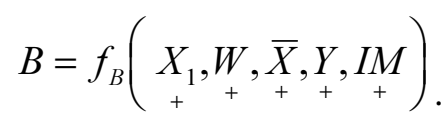

Čia $B$ - nacionalinio biudžeto pajamos, $X_{1}$ - užimtuju skaičius, $W$ - vidutinis mènesinis bruto darbo užmokestis, $\bar{X}$ - imonių ūkinès veiklos pelnas, $Y-$ pridètinè vertè, $I M-$ importas. 
Prekyba. Šiame darbe prekybos rezultatus buvo nuspręsta analizuoti per prekių ir paslaugų paklausos bei pasiūlos prizmę. Vidaus paklausą šalyje tiesiogiai formuoja namų ūkiai ir valdžios sektorius, be to, kadangi Lietuva yra mažos atviros ekonomikos šalis, tai analizuojant būtina atsižvelgti ne tik i vidaus prekybą, bet ir i eksportą bei importą.

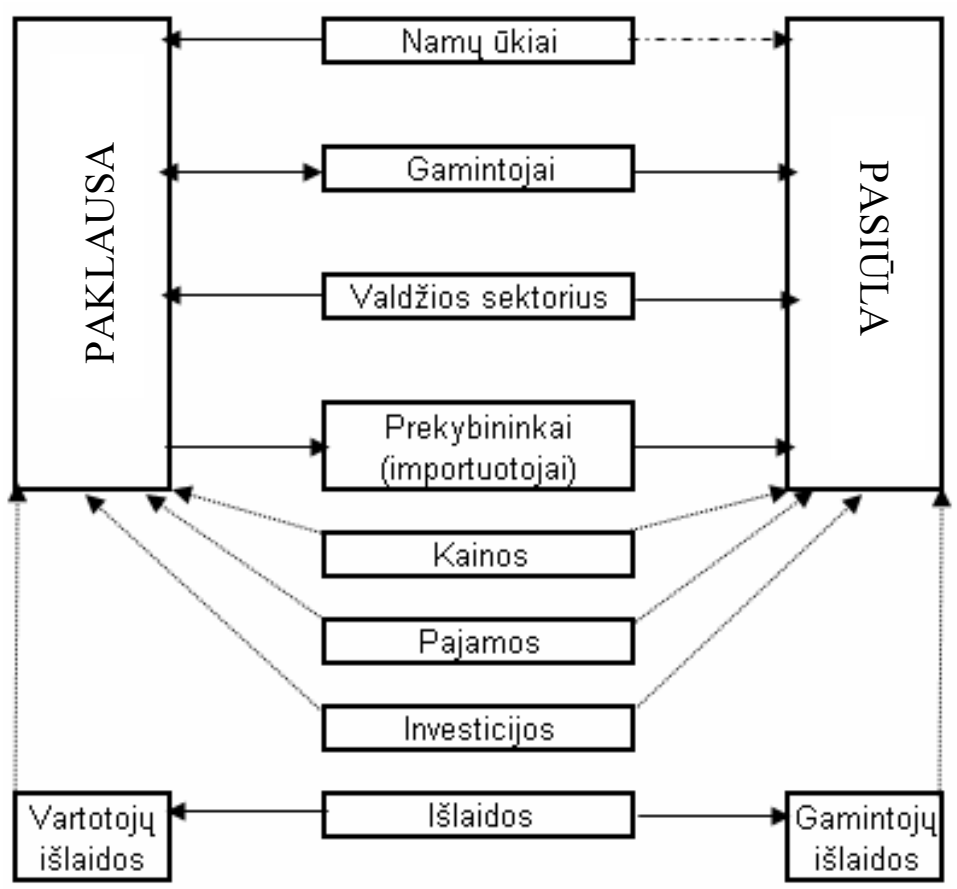

3.5 pav. Pasiūlos ir paklausos formavimas

Fig. 3.5. Factors affecting supply and demand

Namų ūkių vartojimo išlaidos 2012 metais Lietuvoje siekè 71,7 milijardus litų, o per pirmus du $2013 \mathrm{~m}$. ketvirčius, lyginant su praejusių metų atitinkamu laikotarpiu, namų ūkių išlaidos išaugo net 7,4 proc. Tuo tarpu valdžios sektoriaus išlaidos 2012 metais siekè kiek mažiau nei 20 milijardų litų ir pastaruosius ketverius metus keitèsi tik labai nežymiai. Todèl galima teigti, kad prekių ir paslaugu paklausą Lietuvoje daugiausia nulemia namų ūkiai. Tačiau reikia nepamiršti, kad nors ir neženkliai, bet namų ūkiai formuoja ir pasiūlą. Tai daugiausiai vyksta per augalininkystę ir gyvulininkystę, bei asmenis vykdančius individualią veiklą ar dirbančius pagal versto liudijimus. 
Prekių paklausą veikia daugybė veiksnių: kainų pasikeitimas, vartotojo biudžeto dalis, skirta prekėms įsigyti, laikas. Tuo tarpu pasiūlą pirmiausia lemia laikas, po to konkurencingu prekių egzistavimas ir prekių saugojimo galimybès.

Galutinio vartojimo prekių pasiūlą gamintojai formuoja, veikiami esamos prekių ir paslaugu paklausos. O prekybininkai, užsiimantys prekių importu, analizuodami esamą paklausą, formuoja pasiūlą prekių ir paslaugų, kurios Lietuvoje negaminamos arba neteikiamos, arba importuoja konkurencingas prekes ar paslaugas.

Investicijos i gamybą suteikia galimybę gamintojams, naudojant tuos pačius resursus, pagaminti daugiau produkcijos, t. y. padidinti pasiūlą o įdiegtos naujos technologijos dažnai leidžia atpiginti produkcijos gamybą ir taip padidinti prekių konkurencingumą ir paklausa.

3.5 paveiksle pavaizduoti pasiūlą ir paklausą formuojantys bei itakojantys faktoriai. Punktyrinèmis rodyklèmis pažymèti veiksniai, kurie itakoja paklausą ir pasiūla.

Vidaus prekių paklausos aprašymui šiame darbe naudojama lygtis:

$$
D(t) \equiv V_{n}(t)+I(t)+V_{v}(t)-\xi(t) \cdot I M(t)+E X(t) .
$$

Čia $D(t)$ - vidaus prekių paklausa, $V_{n}(t)$ - privatus vartojimas, $I(t)$ - investicijos, $V_{v}(t)$ - valdžios sektoriaus vartojimas, $\xi(t)$ - realus valiutos kursas, $I M(t)-$ importas, $E X(t)$ - eksportas.

Vartojimas priklauso nuo pajamų, todèl namų ūkių ir vadžios sektoriaus išlaidos modeliuojamos naudojant pajamas bei kitus piniginius indikatorius. Namų ūkių vartojimui aprašyti be pajamų naudojama mažmeninės prekybos ir maitinimo įmonių apyvarta:

$$
V_{v}(t)=F(W(t), D P(t), M P(t)) .
$$

Čia $W(t)$ - vidutinis mėnesinis bruto darbo užmokestis, $D P(t)$ - darbo pajamų kreditas, $M P(t)$ - mažmeninès prekybos ir maitinimo i̇monių apyvarta:

$$
G(t)=F\left(B(t), Y_{L}(t), P B(t)\right) .
$$

Čia $B(t)$ - nacionalinio biudžeto pajamos, $Y_{L}(t)$ - viešojo valdymo ir gynybos, privalomojo socialinio draudimo sukurta pridètinè vertè, $P B(t)$ - pinigu bazé: grynieji pinigai apyvartoje, kredito įstaigu einamosios sąskaitos ir privalomosios atsargos.

Investicijos tiesiogiai priklauso nuo dviejų faktorių: ūkinio subjekto pelno ir palūkanų normų. Kadangi pardavimai priklauso nuo vartojimo, tai i modelio lygti itrauktas privataus ir valdžios sektoriaus vartojimas. Jei vartojimas auga, tai imonių prekių ar paslaugų pardavimai taip pat auga, o tuo pačiu didèja ir pelnas. Tačiau norint padidinti produkcijos kieki, reikia didinti investicijas. Kadangi ne 
visuomet investicijoms pakanka uždirbto pelno, tai daugelis įmonių investuojant ima paskolas. Todèl, i modelio lygti itraukiama paskolų apimtis ir palūkanų normos. Jei jos aukštos, tai gali būti, kad investicijų nauda bus žemesnè už palūkanas, ir įmonès nuspręs neinvestuoti. Sudaryta investicijų modelio lygtis:

$$
I(t)=F\left(\bar{X}(t-2), P A(t-1), P N(t-1), V_{n}(t), V_{v}(t-4)\right) .
$$

Čia $\bar{X}(t)$ - įmonių ūkinès veiklos pelnas, $P A(t-1)$ - suteiktų paskolų apimtis per praejjusị laikotarpi, $P N(t-1)$ - praejjusio periodo palūkanų norma, $X_{1}(t)$ - užimtujų skaičius.

Kadangi nèra pakankamai duomenų apie visas investicijų rūšis Lietuvoje, tai šiame darbe apsiribota tik materialinių investicijų modeliavimu.

Importui aprašyti sudaryta importo paklausos funkcija, naudojant vartojimo, investicijų ir eksporto kintamuosius. Importas taip pat priklauso ir nuo produkcijos, bei realaus valiutų kurso. Dèl realaus valiutų kurso didejjimo vidaus prekès santykinai tampa brangesnèmis, palyginti su importuojamomis prekèmis, todèl atsiranda importo augimo galimybès. Ir atvirkščiai - kritus realiam valiutų kursui vidaus prekès tampa santykinai pigesnès, nei importuojamos. Lietuvoje nèra ivertinto ir oficialiai paskelbto realaus valiutos kurso, be to tiksliai ji ivertinti gana sudètinga, kadangi realus valiutos kursas yra susijęs su nominaliu valiutos kursu bei kainomis vidaus ir išorès rinkose. Todèl vertinant importa, buvo nuspręsta naudoti nominalų lito ir užsienio šalių, iš kurių daugiausiai importuojama (Rusijos, Lenkijos ir Latvijos), valiutų santyki. Nors iš Vokietijos taip pat importuojama daug, bet, kadangi lito ir euro santykis yra pastovus, tai i lygti jis netraukiamas:

$$
I M(t)=F\left(V_{n}(t), V_{v}(t), I(t), E X(t-1), \bar{\xi}_{R U}(t-3), \bar{\xi}_{P L}(t-3), \bar{\xi}_{L V}(t-3)\right) .
$$

Čia $\bar{\xi}_{R U}(t)$ - lito ir Rusijos rublio santykis, $\vec{\xi}_{P L}(t)$ - lito ir Lenkijos zloto santykis, $\bar{\xi}_{L V}(t)$ - lito ir Latvijos lato santykis.

Lietuvoje pagaminta produkcija eksportuojama i daugelį šalių. Norint tiksliai aprašyti eksportuojamą produkcija, reikètų analizuoti visų šiu šalių rinkas. Tai nėra šio darbo tikslas. Todèl, eksporto pokyčiams aprašyti naudojama sukurta pridètinè verte, prekių vartojimo Lietuvoje indikatoriai, eksporto kainų indeksas, o valiutų santykių pokyčių i̇taka eksportui tiriama į lygti itraukiant lito ir šalių, i kurias daugiausiai eksportuojama, valiutos santykius:

$$
E X(t)=F\left(Y(t-1), V_{n}(t), V_{v}(t), P_{\text {exp }}(t-1), \bar{\xi}_{R U}(t), \bar{\xi}_{P L}(t), \bar{\xi}_{L V}(t)\right) .
$$

Čia $P_{\text {exp }}(t-1)$ - praejjusio laikotarpio eksportuotų prekių kainų pokyčiai.

Toliau pateikiamos prekybos indikatorių lygčių specifikacijos. 


$$
V_{n}=f_{V_{n}}(\underset{+}{W}, \underset{+}{D P}, \underset{+}{M P}) .
$$

Čia $V_{n}$ - privatus vartojimas, $W$ - vidutinis mėnesinis bruto darbo užmokestis, $D P$ - darbo pajamų kreditas, $M P$ - mažmeninès prekybos ir maitinimo i̇monių apyvarta.

$$
V_{v}=f_{V_{v}}\left(\begin{array}{c}
B, Y_{+}, P B \\
+
\end{array}\right) .
$$

Čia $V_{v}$ - valdžios sektoriaus vartojimas, $B$ - nacionalinio biudžeto pajamos, $Y_{O}-$ viešojo valdymo ir gynybos; privalomojo socialinio draudimo sukurta pridètinè vertè, $P B$ - pinigų bazé: grynieji pinigai apyvartoje, kredito įstaigų einamosios sąskaitos ir privalomosios atsargos.

$$
I=f_{I}\left(\begin{array}{c}
\bar{X}, P A \\
+ \\
+
\end{array}, \underset{+}{P N}, X_{1}\right) .
$$

Čia $I$ - materialinès investicijos, $\bar{X}$ - imonių ūkinès veiklos pelnas, $P A-$ suteiktų paskolų apimtis, $P N-$ palūkanų norma, $X_{1}-$ užimtųjų skaičius.

$$
I M=f_{I M}\left(\begin{array}{c}
V_{n}, V_{v}, I, E X, \bar{\xi}_{R U}, \bar{\xi}_{P L} \\
+++_{+}
\end{array}\right) .
$$

Čia $I M$ - importas, $V_{n}$ - privatus vartojimas, $V_{v}$ - valdžios sektoriaus vartojimas, $I$ - investicijos, $E X$ - eksportas, $\bar{\xi}_{R U}(t)$ - lito ir Rusijos rublio santykis, $\bar{\xi}_{P L}(t)-$ lito ir Lenkijos zloto santykis.

$$
E X=f_{E X}\left(\begin{array}{c}
V_{n}, V_{v}, I, P_{+} P_{+}, \bar{\xi}_{L V} \\
-{ }_{-}
\end{array}\right) .
$$

Čia $E X$ - eksportas, $V_{n}$ - privatus vartojimas, $V_{v}-$ valdžios sektoriaus vartojimas, $P_{\text {exp }}$ - eksportuotu prekių kainų indeksas, $\bar{\xi}_{L V}(t)$ - lito ir Latvijos lato santykis.

3.1 lentelejje pateiktos visų modelio lygčių sudedamujų dalių aprašančių lygčiu specifikacijos ir susisteminti struktūriniai modelio ryšiai. Lygtyse nurodyti indikatoriai, galintys reikšmingai įtakoti, nagrinèjamus kintamuosius. Apačioje nurodyti tikètini šių indikatorių parametrų ženklai. 


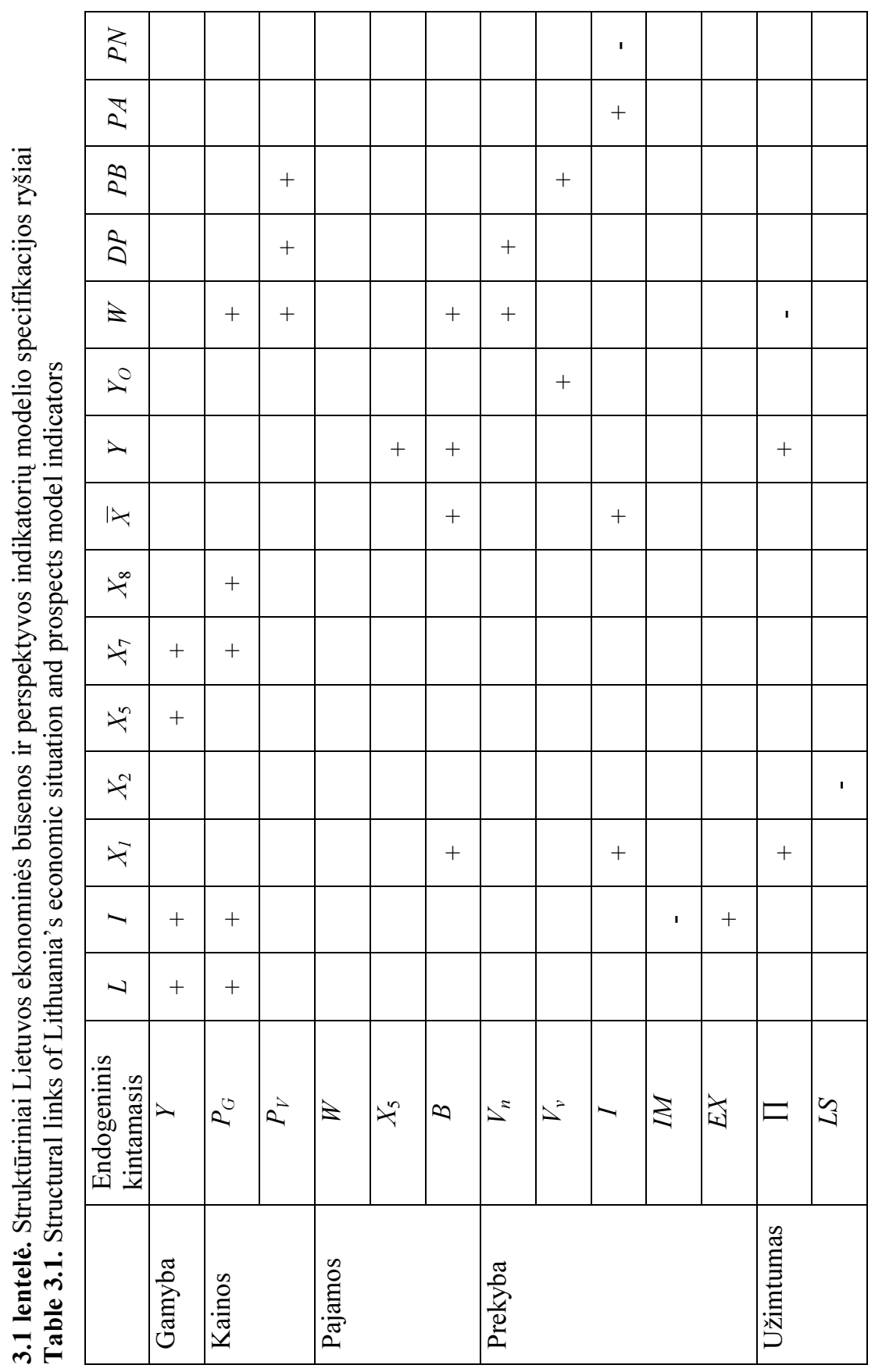




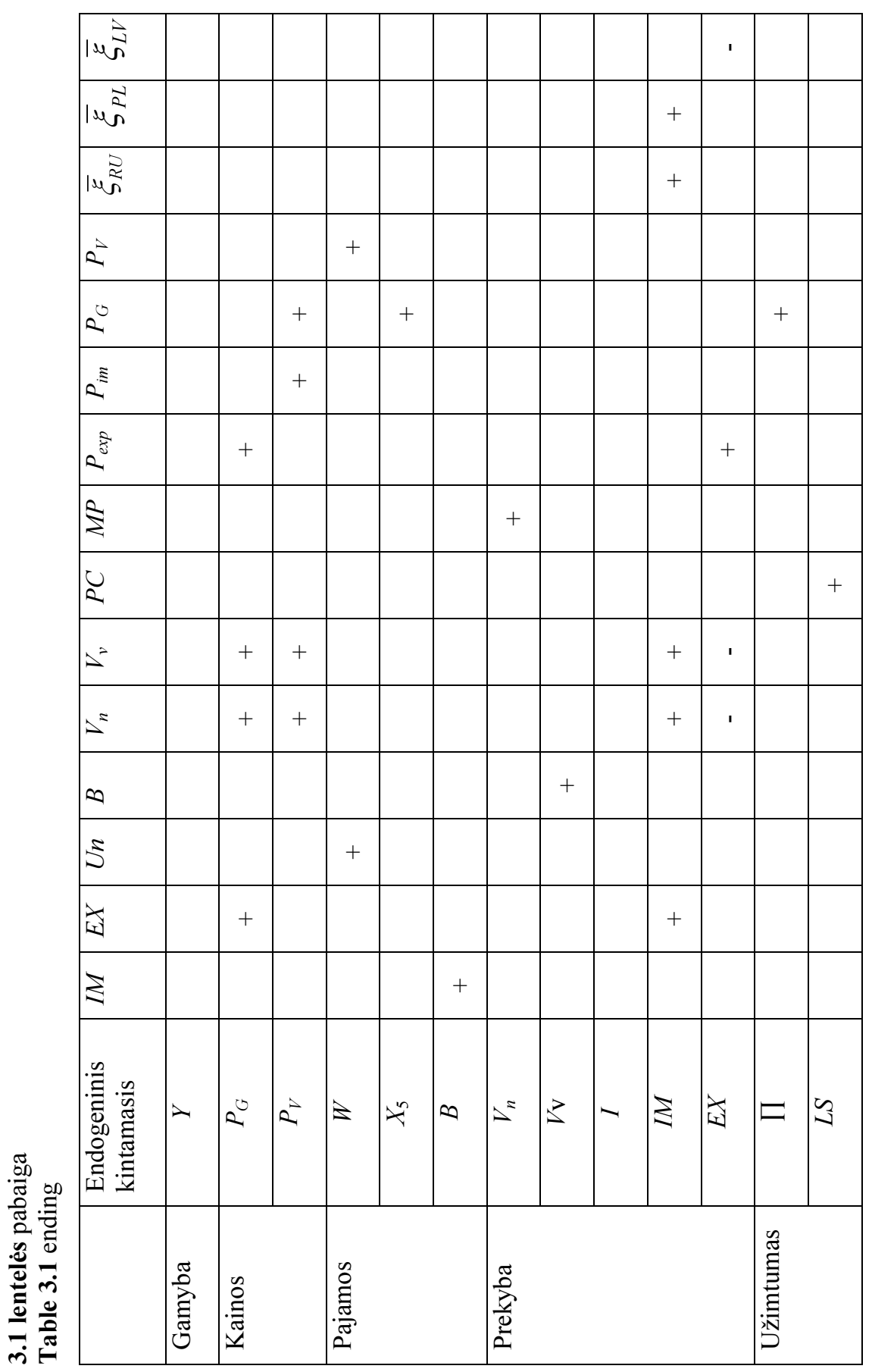




\subsubsection{Modelio lygčių parametrų vertinimo eiga ir rezultatai}

Atrinkus tarpusavyje nekoreliuojančius egzogeninius kintamuosius, pagal ankstesniuose skyriuose aprašytą metodika, tikrinama hipotezè dèl regresijos lygties adekvatiškumo, t. y. iškeliama nulinè hipoteze, kad nè vienas veiksnys reikšmingai neįtakoja priklausomo kintamojo $\left\{\begin{array}{l}H_{0}: b_{1}=b_{2}=\ldots=b_{k}=0, \\ H_{1}: \text { bent vienas } b_{j} \neq 0 .\end{array}\right.$. Hipotezès tikrinimui naudojama F statistika:

$$
F_{k, n-k-1}=\frac{\frac{1}{k} \sum_{i=1}^{n}\left(\hat{y}_{i}-\bar{y}\right)^{2}}{\frac{1}{n-k-1} \sum_{i=1}^{n}\left(y_{i}-\hat{y}_{i}\right)^{2}} .
$$

Jei hipotezè, kad visi parametrai prie nepriklausomų kintamujų yra nereikšmingi, atmetama, tuomet tikriname kiekvieno regresoriaus reikšmingumą ir naudojame laipsniško veiksnių atmetimo procedūrą. Hipotezès apie tam tikro nepriklausomojo kintamojo reikšmingumą tikrinimui $\left\{\begin{array}{l}H_{0}: b_{j}=0, \\ H_{1}: b_{j} \neq 0 .\end{array}\right.$, naudojamas Stjudento kriterijus:

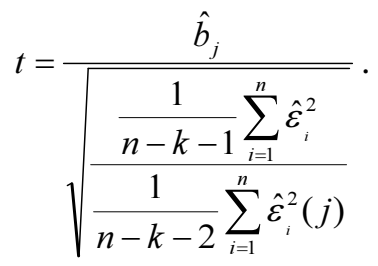

Čia $\sum_{i=1}^{n} \hat{\varepsilon}_{i}^{2}(j)$ - regresijos modelio, kuriame $X_{j}$ yra priklausomas kintamasis, o $X_{1}, \ldots, X_{j-1}, X_{j+1}, \ldots, X_{n}$ - nepriklausomi kintamieji, liekamuju paklaidų kvadratų suma.

Modelio lygčių parametrų ivverčiai buvo apskaičiuoti taikant mažiausių kvadratų metoda.

Kadangi atlikus modelių tikslumo analizę, naudojant modeliuotas sekas, nustatyta, kad norint pasiekti didesni tiksluma, prieš modeliuojant tikslinga eliminuoti sezoninę komponentę, tai vertintos modelio lygtis bendruoju pavidalu galima užrašyti: $y(t)=s(t)+f\left(x_{1}(t), x_{2}(t), \ldots, x_{n}(t)\right)$. 
Prieš sudarant modelio lygtis, patikrinta ar laiko eilutejje nèra išsiskiriančių (adityvių, lygio postūmio, praeinančių pokyčių) reikšmių. Jas aptikus, išskirtims aprašyti į modelio lygti itraukti fiktyvieji kintamieji.

Kad neišplèsti šio darbo apimties, žemiau pateikta dalis sudarytų lygčių su ivertintais parametrais ir ju reikšmingumais. Kitos modelio lygtys pateiktos F priede. Po lygtimis surašytos pagrindinès statistinès lygties charakteristikos: modelio lygčiu adekvatumo - determinacijos koeficientas $\mathrm{R}^{2}$, liekanų autokoreliacijos - Durbin-Watson, ir santykinès absoliutinès modelių lygčių paklaidos (toliau ją žymėsime $l$ ).

Užimtumas. Pirmiausia sudaromos lygtys faktiškai dirbtoms valandoms, po to vertinamas užimtujų skaičius. Faktiškai dirbtos valandos ir užimtujų skaičius vertinami pagal 21 ekonominę veiklos rūši. Visos dirbtos valandos ir visi užimtieji apskaičiuojami agreguojant gautus ivverčius. Čia teikiamos tik trijų veiklų, kurioms tenka didesnioji dalis užimtujų, lygtys:

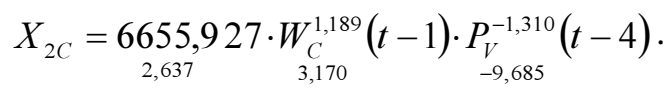

Čia $X_{2 C}$ - faktiškai dirbtos valandos apdirbamojoje gamyboje, $P_{V}-$ suderintas vartotojų kainų indeksas.

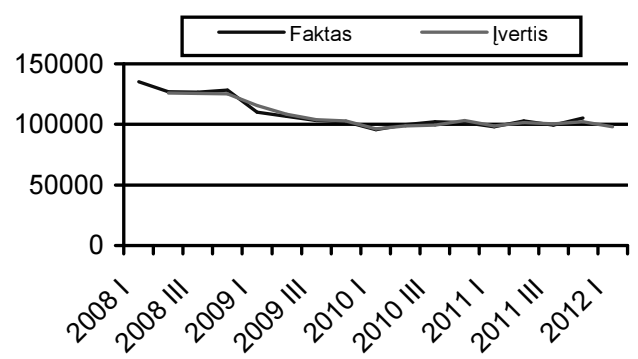

3.6 pav. Dirbtų valandų apdirbamojoje gamyboje modeliavimo rezultatai

Fig. 3.6. Results of modelling of the worked hours in manufacturing

Ivertinto modelio paklaida pakankamai žema $-l=1,70 \%$; determinacijos koeficientas rodo aukštą modelio adekvatumą $-R^{2}=0,96$, o Durbin-Watson statistika parodo, kad gauto modelio paklaidos nèra autokorteliuotos $D W=2,10$.

$$
X_{2 G}=\underset{10,815}{6,727 \cdot 10^{5}} \cdot P_{-3,554}^{-0,632}(t-3) \cdot X_{3,083}^{0,087}(t-1) .
$$


Čia $X_{2 G}$ - faktiškai dirbtos valandos didmeninès ir mažmeninès prekybos, varikliniu transporto priemoniu ir motociklu remonto veiklose - suderintas vartotojų kainų indeksas, $X_{3}$ - materialinės investicijos.

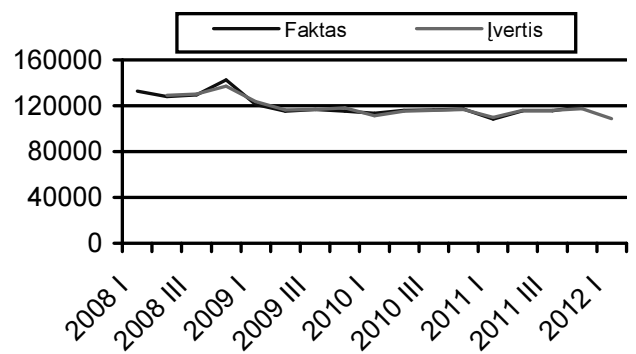

3.7 pav. Dirbtų valandų didmeninės ir mažmeninès prekybos, variklinių transporto priemoniu ir motociklų remonto veiklose modeliavimo rezultatai

Fig. 3.7. Results of modelling of the worked hours in wholesale and retail trade; repair of motor vehicles and motorcycles

Ivertinto modelio paklaida pakankamai žema $-l=1,02 \%$; determinacijos koeficientas rodo aukštą modelio adekvatumą $-R^{2}=0,92$, o Durbin-Watson statistika rodo, kad gauto modelio paklaidos nèra reikšmingai autokorteliuotos.

$$
X_{2 H}=\underset{-1,098}{27820,335}+\underset{3,123}{43,636} W_{H}(t-1)-\underset{-4,122}{0,004} X_{3}(t-3) .
$$

Čia $X_{2 H}$ - faktiškai dirbtos valandos transporto ir saugojimo veiklose, $W_{H}-$ darbo užmokestis transporto ir saugojimo veiklose, $X_{3}-$ materialinès investicijos.

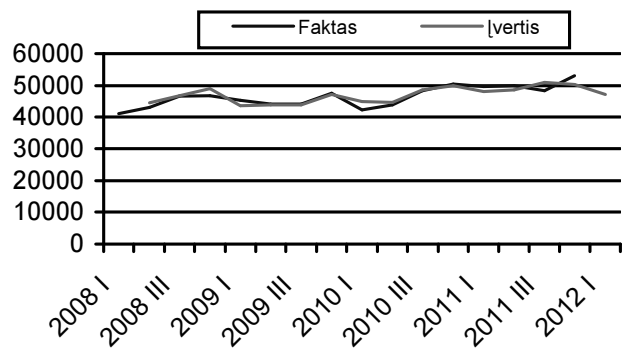

3.8 pav. Dirbtu valandų transporto ir saugojimo veiklose modeliavimo rezultatai

Fig. 3.8. Results of modelling of the worked hours in transporting and storage 
Ivertinto modelio paklaida $-l=2,66 \%$; determinacijos koeficientas rodantis modelio adekvatuma $-R^{2}=0,63$, o Durbin-Watson statistika parodo, kad gauto modelio paklaidos nèra autokorteliuotos $D W=2,28$.

Toliau pateikti įvertintos užimtujjų skaičiaus modelio lygtys:

$$
X_{1 C}=\underset{-0,954}{0,135} \cdot \underset{6,560}{X_{6,0}^{0,407}}(t-2) \cdot P_{-4,971}^{-0,762}(t-3) \cdot \underset{4,051}{X_{4}^{0,366}}(t-2) .
$$

Čia $X_{1 C}$ - užimtujų skaičius apdirbamojoje gamyboje, $X_{2 C}$ - faktiškai dirbtos valandos apdirbamojoje gamyboje, $P_{V}$ - suderintas vartotojų kainų indeksas, $X_{4}$ - tiesioginès užsienio investicijos.

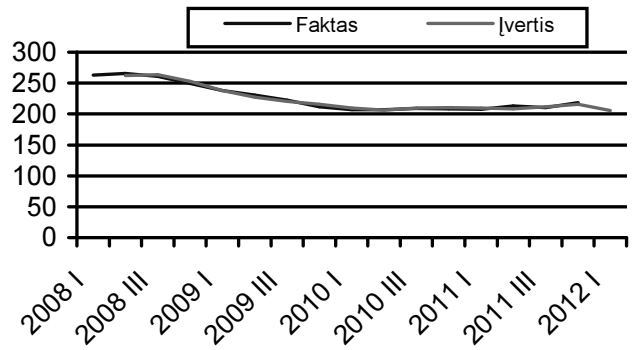

3.9 pav. Užimtujų skaičiaus apdirbamojoje gamyboje modeliavimo rezultatai

Fig. 3.9. Results of modelling of the employment in manufacturing

Ivertinto modelio paklaida pakankamai žema $-l=0,98 \%$; determinacijos koeficientas rodo aukštą modelio adekvatumą $-R^{2}=0,98$, o Durbin-Watson statistika parodo, kad gauto modelio paklaidos nèra autokorteliuotos $D W=2,00$.

$$
X_{1 G}=\underset{-5,065}{3,920 \cdot 10^{-13}} \cdot \underset{2 G, 647}{X_{10,282}^{1,28}}(t) \cdot \underset{-2,664}{P_{-1,658}^{-1}}(t-1) \cdot \underbrace{0,089}_{3,900}(t-4) \cdot \underset{3,672}{X_{3 G}^{1,681}}(t-1) .
$$

Čia $X_{1 G}$ - užimtujų skaičius didmeninès ir mažmeninès prekybos, variklinių transporto priemonių ir motociklų remonto veiklose, $X_{2 G}$ - faktiškai dirbtos valandos didmeninès ir mažmeninès prekybos, variklinių transporto priemonių ir motociklų remonto veiklų imonėse, $P_{V}$ - suderintas vartotojų kainų indeksas, $X_{3}$ - materialinès investicijos, $X_{4 G}$ - tiesioginès užsienio investicijos didmeninès ir mažmeninès prekybos, variklinių transporto priemonių ir motociklų remonto veiklose. 


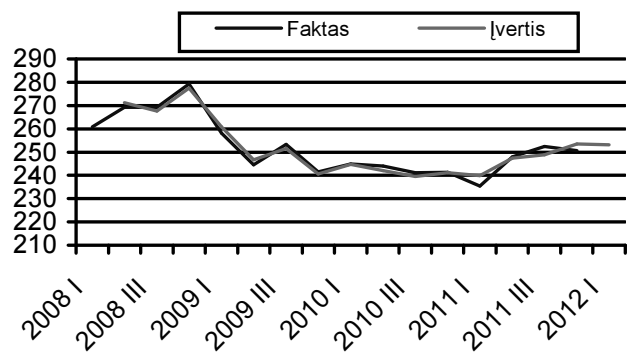

3.10 pav. Užimtujų skaičiaus didmeninès ir mažmeninès prekybos, variklinių transporto priemonių ir motociklų remonto veiklose modeliavimo rezultatai

Fig. 3.10. Results of modelling of the employment in wholesale and retail trade; repair of motor vehicles and motorcycles

Ivertinto modelio paklaida pakankamai žema $-l=0,79 \%$; determinacijos koeficientas rodo aukštą modelio adekvatumą $-R^{2}=0,96$, o Durbin-Watson statistika parodo, kad gauto modelio paklaidos nèra autokorteliuotos $D W=2,10$.

$$
X_{1 H}=\underset{0,631}{9,120} \underset{4,892}{0,001} X_{2 H}(t) \underset{-2,350}{0,324} P_{V}(t-1)+\underset{5,861}{1,978 \cdot 10^{-6}} X_{4}(t-1) .
$$

Čia $X_{1 H}$ - užimtujų skaičius transporto ir sandèliavimo veiklose, $X_{2 H}$ faktiškai dirbtos valandos transporto ir sandèliavimo veiklose, $P_{V}$ - suderintas vartotojų kainų indeksas, $X_{4}$ - tiesioginès užsienio investicijos.

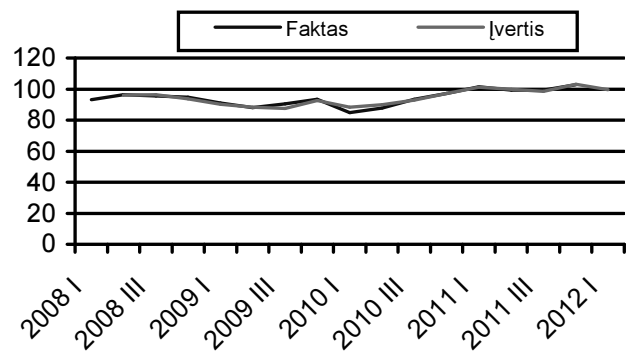

3.11 pav. Užimtujų skaičiaus transporto ir saugojimo veiklose modeliavimo rezultatai

Fig. 3.11. Results of modelling of the employment in transporting and storage

Ivertinto modelio paklaida pakankamai žema $-l=1,22 \%$; determinacijos koeficientas rodo aukštą modelio adekvatumą $-R^{2}=0,92$, o Durbin-Watson statistika parodo, kad gauto modelio paklaidos nèra autokorteliuotos $D W=1,76$. 
Gamyba. Gamybos dalyje modeliuojama 21 ekonominès veiklos rūšiu pridètinè vertè. Čia teikiamos tik trijų veiklų, kuriose sukuriama daugiausiai pridètinès vertès, lygtys.

$$
Y_{C}(t)=\underset{3,395}{1875,735}+\underset{5,114}{0,582} Y_{C}(t-1)-\underset{-4,187}{6,850} X_{1 C}(t-3)+\underset{3,246}{1,545 \cdot 10^{-4}} X_{4 C} .
$$

Čia $Y_{C}$ - pridètinè vertè sukurta apdirbamojoje gamyboje, $X_{1 C}-$ užimtujų skaičius apdirbamojoje gamyboje, $X_{4 C}$ - tiesioginès užsienio investicijos apdirbamajai gamybai.

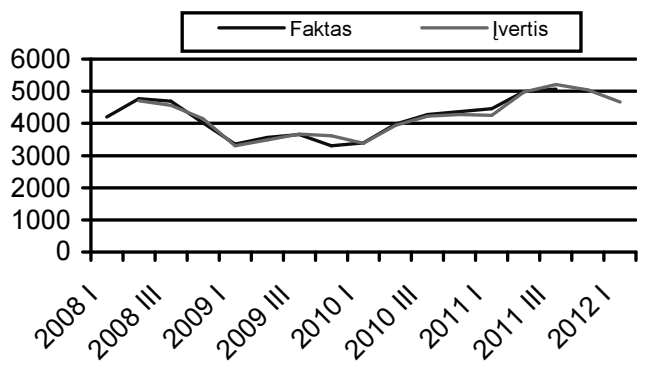

3.12 pav. Pridètinès vertès apdirbamojoje gamyboje modeliavimo rezultatai

Fig. 3.12. Results of modelling of the value added in manufacturing

Ivertinto modelio paklaida $-l=2,42 \%$; determinacijos koeficientas rodo aukštą modelio adekvatumą $-R^{2}=0,95$, o Durbin-Watson statistika parodo, kad gauto modelio paklaidos nèra autokorteliuotos $D W=1,60$.

$$
\begin{aligned}
& Y_{G}(t)=\underset{4,194}{4985,835} \underset{-3,446}{9,693} X_{1 G}(t-3)+\underset{2,235}{2,901 \cdot 10^{-4}} X_{4 G}(t-1)+ \\
& +\underset{12,042}{1,070 \cdot 10^{-4} X_{5 G}(t-1)-1,366 \cdot 10^{-4} X_{7 G}(t-4) .}
\end{aligned}
$$

Čia $Y_{G}$ - pridètinè vertè sukurta didmeninèje ir mažmeninejje prekyboje, variklinių transporto priemonių ir motociklų remonto veiklose, $X_{1 G}-$ užimtujjų skaičius didmeninès ir mažmeninès prekybos, variklinių transporto priemonių ir motociklų remonto veiklose, $X_{4 G}$ - tiesioginès užsienio investicijos didmeninès ir mažmeninès prekybos, variklinių transporto priemonių ir motociklų remonto veiklose, $X_{5 G}$ - pardavimo pajamos didmeninès ir mažmeninès prekybos, variklinių transporto priemonių ir motociklų remonto veiklose, $X_{7 G}$ - nuosavas kapitalas didmeninès ir mažmeninès prekybos, variklinių transporto priemonių ir motociklų remonto veiklose. 


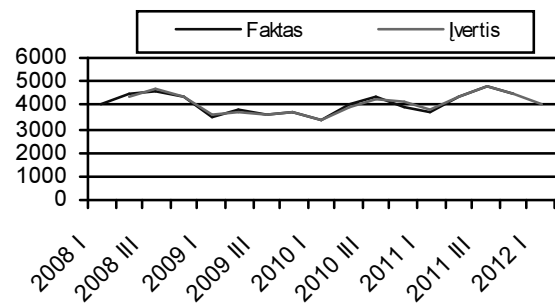

3.13 pav. Pridètinès vertès didmeninès ir mažmeninès prekybos, variklinių transporto priemonių ir motociklų remonto veiklose modeliavimo rezultatai

Fig. 3.13. Results of modelling of the value added in wholesale and retail trade; repair of motor vehicles and motorcycles

Ivertinto modelio paklaida pakankamai žema $-l=1,34 \%$; determinacijos koeficientas rodo aukštą modelio adekvatumą $-R^{2}=0,96$, o Durbin-Watson statistika parodo, kad gauto modelio paklaidos nèra autokorteliuotos $D W=2,28$.

$$
Y_{H}(t)=\underset{-10,316}{2042,912}-\underset{-4,607}{0,032} X_{2 H}(t-1)+\underset{17,062}{0,001} X_{7 H}(t-1) .
$$

Čia $Y_{H}$ - pridètinè verte sukurta transporto ir sandèliavimo veiklose, $X_{2 H}-$ faktiškai dirbtos valandos transporto ir sandèliavimo veiklose, $X_{7 H}$ - nuosavas kapitalas transporto ir sandèliavimo veiklose.

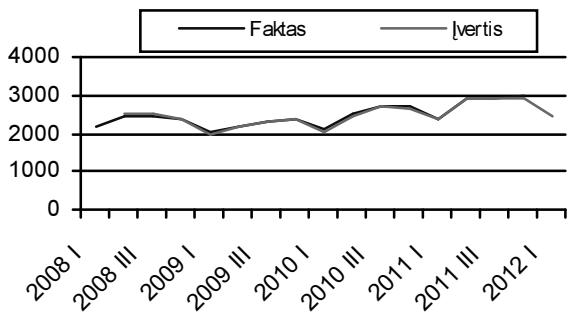

3.14 pav. Pridètinès vertès transporto ir saugojimo veiklose modeliavimo rezultatai

Fig. 3.14. Results of modelling of the value added in transporting and storage

Ivertinto modelio paklaida pakankamai žema $-l=1,29 \%$; determinacijos koeficientas rodo aukštą modelio adekvatumą $-R^{2}=0,98$, o Durbin-Watson statistika parodo, kad gauto modelio paklaidos nèra autokorteliuotos $D W=1,94$.

Kainos. Gamintojų visos parduotos pramonės produkcijos kainų indeksų lygtys sudaromos atskirai kasybos ir karjerų eksploatavimo, apdirbamosios gamybos, elektros, dujų, garo tiekimo ir oro kondicionavimo, bei vandens tiekimo, nuotekų valymo, atliekų tvarkymo ir regeneravimo veikloms. Visos gamintoju parduotos pramonès produkcijos kainų indeksas apskaičiuojamas agreguojant 
šių keturių veiklų grupių ivvertintus indeksus pagal Laspeireso formulę (naudojant bazinius svorius).

$$
P_{G B}(t)=\underset{12,069}{219,806} \underset{-10,880}{0,092} X_{2 B}(t-3) \underset{11,539}{0,011} V_{n}(t-1)-\underset{-5,775}{0,017} V_{v}(t-1) .
$$

Čia $P_{G B}$ - gamintojų parduotos pramonès produkcijos kasybos ir karjerų eksploatavimo veikloje kainų indeksas, $X_{2 B}$ - faktiškai dirbtos valandos kasyboje ir karjerų eksploatavime, $V_{n}-$ namų ūkių vartojimo išlaidos, $V_{\mathrm{v}}-$ valdžios sektoriaus vartojimo išlaidos.

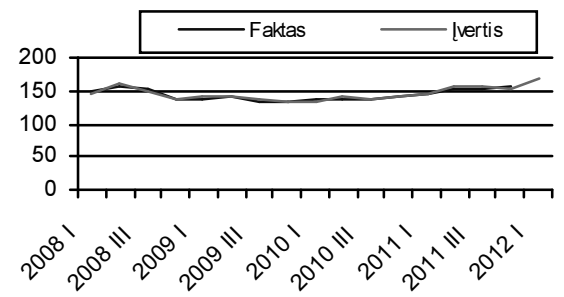

3.15 pav. Gamintojų parduotos pramonès produkcijos kasybos ir karjerų eksploatavimo veikloje kainų indekso modeliavimo rezultatai

Fig. 3.15. Results of modelling of the producer price index in mining and quarrying

Ivertinto modelio paklaida pakankamai žema $-l=1,16 \%$; determinacijos koeficientas rodo aukštą modelio adekvatumą $-R^{2}=0,93$, o Durbin-Watson statistika parodo, kad gauto modelio paklaidos nèra autokorteliuotos $D W=2,48$.

$$
P_{G C}(t)=\underset{23,376}{72,073}+\underset{7,196}{2,258 \cdot 10^{-6}} X_{8 C}(t-1)+\underset{5,482}{2,675 \cdot 10^{-6}} X_{4 C}(t-1) .
$$

Čia $P_{G C}$ - gamintojų parduotos pramonès produkcijos apdirbamojoje gamyboje kainu indeksas, $Y_{8 C}$ - parduota pramonès produkcija apdirbamojoje gamyboje, $X_{4 C}$-tiesioginès užsienio investicijos apdirbamojoje gamyboje.

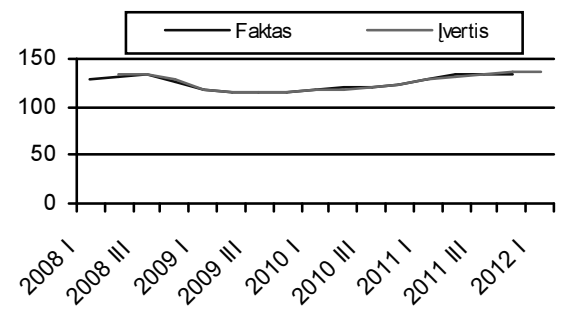

3.16 pav. Gamintojų parduotos pramonės produkcijos apdirbamojoje gamyboje kainų indekso modeliavimo rezultatai

Fig. 3.16. Results of modelling of the producer price index in manufacturing 
Ivertinto modelio paklaida pakankamai žema $-l=0,77 \%$; determinacijos koeficientas rodo aukštą modelio adekvatumą $-R^{2}=0,97$, o Durbin-Watson statistika parodo, kad gauto modelio paklaidos nèra autokorteliuotos $D W=1,85$.

$$
\begin{aligned}
& P_{G D}(t)=\underset{3,652}{41,284-1,587,093} X_{1 D}(t-1)+\underset{7,530}{0,610} P_{\exp }(t-2)+\underset{2,828}{1,550 \cdot 10^{-5}} X_{8 D}(t-2)+ \\
& +\underset{8,371}{9,961 \cdot 10^{-7}} X_{7}(t-2)-\underset{-3,798}{0,003} V_{n}(t-4) \text {. }
\end{aligned}
$$

Čia $P_{G D}$ - gamintojų parduotos pramonès produkcijos elektros, dujų, garo tiekimo ir oro kondicionavimo veiklose kainu indeksas, $X_{1 D}-$ užimtujų skaičius elektros, dujų, garo tiekimo ir oro kondicionavimo veiklose, $P_{\exp }-$ eksporto kainų indeksas, $X_{8 D}$ - parduota pramonès produkcija elektros, dujų garo tiekimo ir oro kondicionavimo veiklose, $X_{7}$ - nuosavas kapitalas, $V_{n}-$ namų ūkių vartojimo išlaidos.

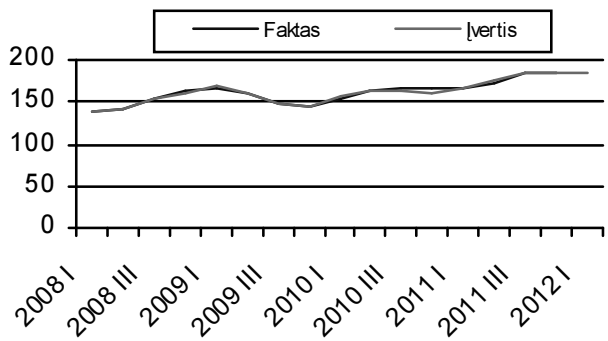

3.17 pav. Gamintojų parduotos pramonės produkcijos elektros, dujų, garo tiekimo ir oro kondicionavimo veiklose kainų indekso modeliavimo rezultatai

Fig. 3.17. Results of modelling of the producer price index in electricity, gas, steam and air conditioning supply

Ivertinto modelio paklaida pakankamai žema $-l=1,06 \%$; determinacijos koeficientas rodo aukštą modelio adekvatumą $-R^{2}=0,99$, o Durbin-Watson statistika parodo, kad gauto modelio paklaidos nèra autokorteliuotos $D W=1,97$.

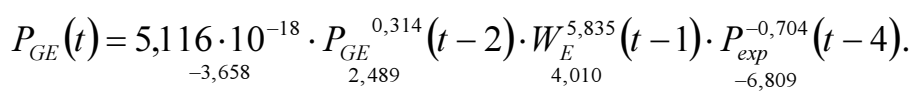

Čia $P_{G E}$ - gamintojų parduotos pramonès produkcijos vandens tiekimo, nuoteku valymo, atliekų tvarkymo ir regeneravimo veiklose kainų indeksas, $X_{1 D}-$ užimtuju skaičius elektros, dujų, garo tiekimo ir oro kondicionavimo veiklose, $P_{\text {exp }}$ - prekių ir paslaugu eksportas, $W_{E}$ - vidutinis ménesinis bruto darbo užmokestis vandens tiekimo, nuotekų valymo, atliekų tvarkymo ir regeneravimo veiklose. 

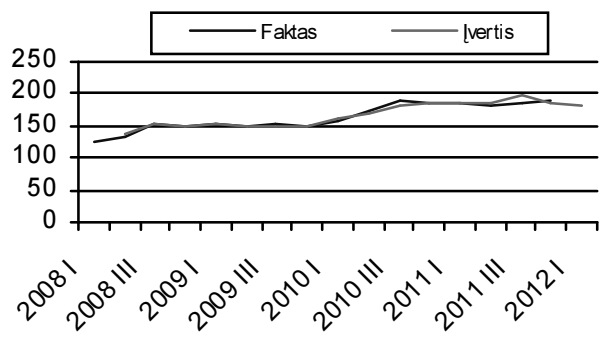

3.18 pav. Gamintojų parduotos pramonès produkcijos vandens tiekimo, nuotekų valymo, atliekų tvarkymo ir regeneravimo kainų indekso modeliavimo rezultatai

Fig. 3.18. Results of modelling of the producer price index in water supply; sewerage; waste management and remediation activities

Ivertinto modelio paklaida $-l=2,05 \%$; determinacijos koeficientas rodo aukštą modelio adekvatumą $-R^{2}=0,96$, o Durbin-Watson statistika parodo, kad gauto modelio paklaidos nèra autokorteliuotos $D W=1,83$.

Toliau vertintos 12 grupių suderinto vartotojų kainų indeksų lygtys. Čia pateikiamos trijų grupių, kurių didžiausias svoris vertinant SVKI, lygtys. Visų parduotų prekių ar paslaugų kainų indeksas apskaičiuojamas agreguojant ivertintus 12 grupių kainų indeksus pagal Laspeireso formulę (naudojant bazinius svorius).

$$
P_{V M}(t)=\underset{1,562}{1,988} \cdot \underset{11,829}{P_{1,862}^{0,8}}(t-1) \cdot V_{-2,822}^{-0,281}(t-1) \cdot W_{4,798}^{0,319}(t-3) .
$$

Čia $P_{V M}$ - suderinto vartotojų kainų maisto ir nealkoholinių gèrimų grupès indeksai, $P_{G}$ - gamintoju parduotos pramonès produkcijos kainų indeksas, $V_{v}-$ valdžios sektoriaus vartojimo išlaidos, $W$ - vidutinis ménesinis bruto darbo užmokestis.

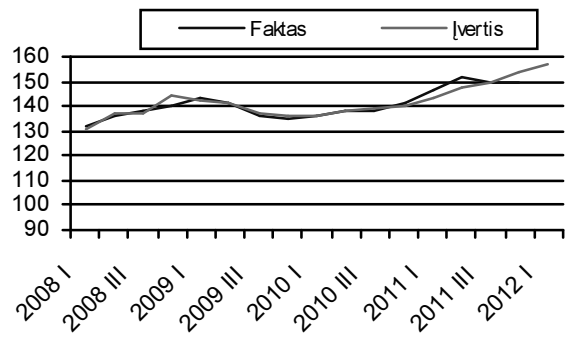

3.19 pav. Suderinto vartotojų kainų maisto ir nealkoholinių gérimų grupès indekso modeliavimo rezultatai

Fig. 3.19. Results of modelling of the harmonised consumer price index of the food and non-alcoholic beverages 
Ivertinto modelio paklaida pakankamai žema $-l=0,93 \%$; determinacijos koeficientas rodo aukštą modelio adekvatumą $-R^{2}=0,97$, o Durbin-Watson statistika parodo, kad gauto modelio paklaidos nèra autokorteliuotos $D W=1,64$.

$$
P_{V B}(t)=\underset{-3,773}{4,858 \cdot 10^{-13}} \cdot P_{G B}^{0,583}(t-1) \cdot P_{-3,494}^{-0,356}(t-4) \cdot P B_{-2,325}^{-0,161}(t-1) \cdot W_{D}^{4,212}(t-1) .(3.53)
$$

Čia $P_{V B}$ - suderinto vartotojų kainų būsto, vandens, elektros, dujų ir kito kuro grupès indeksai, $P_{G}$ - gamintojų parduotos pramonès produkcijos kainų indeksas elektros, dujų, garo tiekimo ir oro kondicionavimo veiklose, $P_{i m}$ - importo kainų indeksas, $P B(\mathrm{t})$ - pinigu bazé, $W_{D^{-}}$vidutinis mènesinis bruto darbo užmokestis elektros, dujų, garo tiekimo ir oro kondicionavimo veiklose.

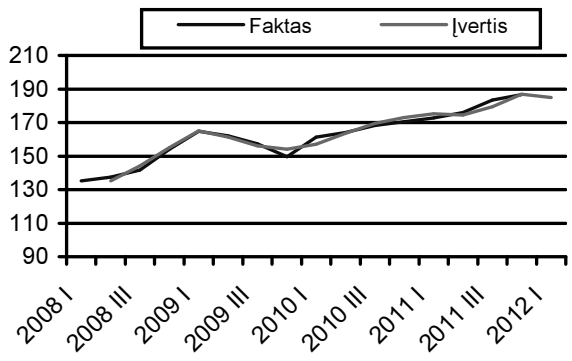

3.20 pav. Suderinto vartotojų kainų būsto, vandens, elektros, dujų ir kito kuro grupès indekso modeliavimo rezultatai

Fig. 3.20. Results of modelling of the harmonised consumer price index of the housing, water, electricity, gas and other fuels

Ivertinto modelio paklaida pakankamai žema $-l=1,16 \%$; determinacijos koeficientas rodo aukštą modelio adekvatumą $-R^{2}=0,97$, o Durbin-Watson statistika parodo, kad gauto modelio paklaidos nèra autokorteliuotos $D W=2,29$.

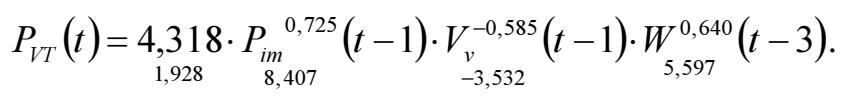

Čia $P_{V T}$ - suderinto vartotojų kainų transporto grupès indeksai, $P_{i m}$ - importo kainų indeksas, $V_{v}$ - valdžios sektoriaus vartojimo išlaidos, $W$ - vidutinis mènesinis bruto darbo užmokestis. 


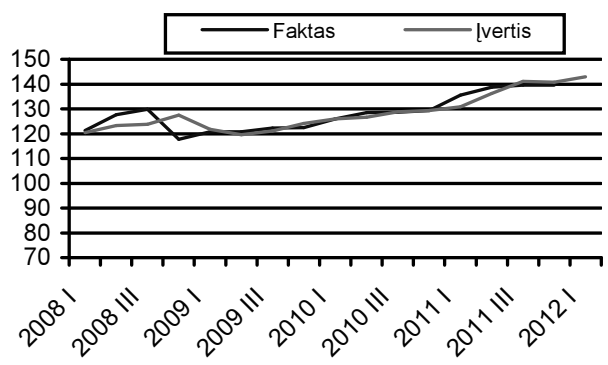

3.21 pav. Suderinto vartotojų kainų transporto grupès indekso modeliavimo rezultatai Fig. 3.21. Results of modelling of the harmonised consumer price index of the transport

Ivertinto modelio paklaida pakankamai žema $-l=1,07 \%$; determinacijos koeficientas rodo aukštą modelio adekvatumą $-R^{2}=0,89$, o Durbin-Watson statistika parodo, kad gauto modelio paklaidos nèra autokorteliuotos $D W=2,04$.

Pajamos. Ivertinta vidutinio mėnesinio bruto darbo užmokesčio modelio lygtis:

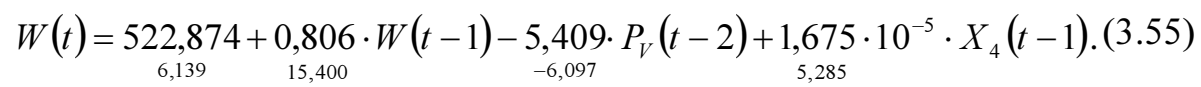

Čia $W$ - vidutinis mènesinis bruto darbo užmokestis, $P_{V}$ - suderinto vartotojų kainų indeksai, $X_{4}$ - tiesioginès užsienio investicijos.

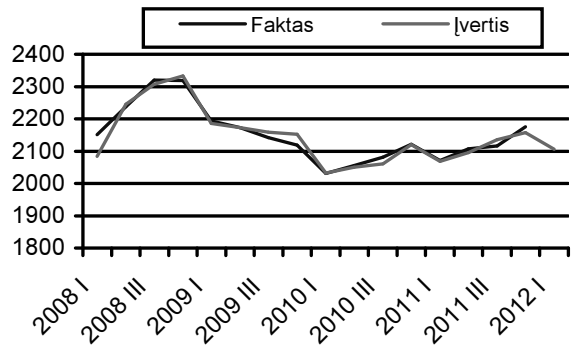

3.22 pav. Vidutinio mėnesinio bruto darbo užmokesčio modeliavimo rezultatai

Fig. 3.22. Results of modelling of the average monthly earnings

Ivertinto modelio paklaida pakankamai žema $-l=0,55 \%$; determinacijos koeficientas rodo aukštą modelio adekvatumą $-R^{2}=0,97$, o Durbin-Watson statistika parodo, kad gauto modelio paklaidos nèra autokorteliuotos $D W=2,15$.

Valstybinio socialinio draudimo senatvès pensijos modeliavimui buvo naudotas ASETAR metodas. 


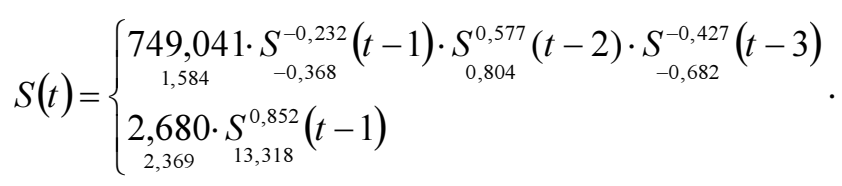

Čia S - valstybinio socialinio draudimo senatvès pensija.
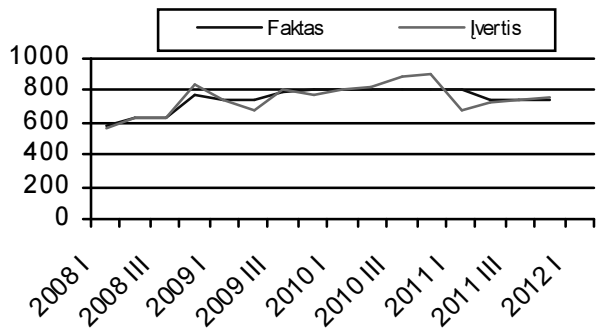

3.23 pav. Valstybinio socialinio draudimo senatvès pensijos modeliavimo rezultatai

Fig. 3.23. Results of modelling of the old-age pension paid

Ivertinto modelio paklaida $-l=4,89 \%$; slenksčio kintamojo reikšmè $-r$ $=446,01$, o poslinkio parametras $d=1$.

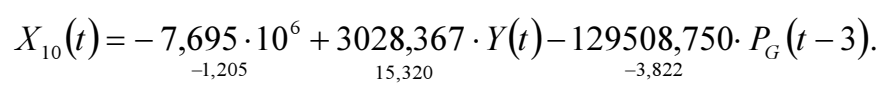

Čia $X_{10}$ - bendrasis imonių ūkinès veiklos pelnas, $Y$ - pridètinè vertè, $P_{G}-$ gamintojų Lietuvos rinkoje parduotos produkcijos kainų indeksas.

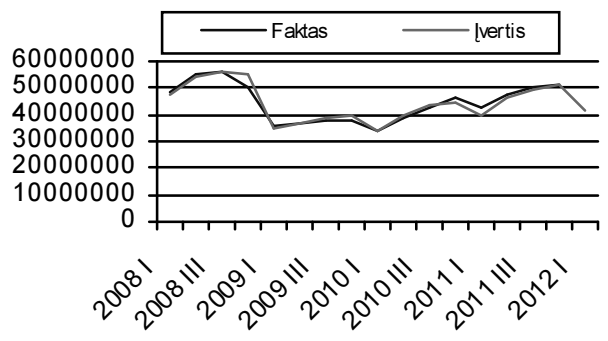

3.24 pav. Bendrojo įmonių ūkinès veiklos pelno modeliavimo rezultatai

Fig. 3.24. Results of modelling of the general profit of the enterprises

Ivertinto modelio paklaida $-l=2,40 \%$; determinacijos koeficientas rodo aukštą modelio adekvatumą $-R^{2}=0,94$, o Durbin-Watson statistika parodo, kad gauto modelio paklaidos nèra autokorteliuotos $D W=1,77$. 


$$
B(t)=\left\{\begin{array}{l}
2,933 \cdot B_{8,018}^{0,929}(t-1) \\
0,619 \\
3,333 \cdot 10^{7} \cdot B_{-0,718}^{-0,114}(t-1)
\end{array} .\right.
$$

Čia $B$ - nacionalinio biudžeto pajamos.

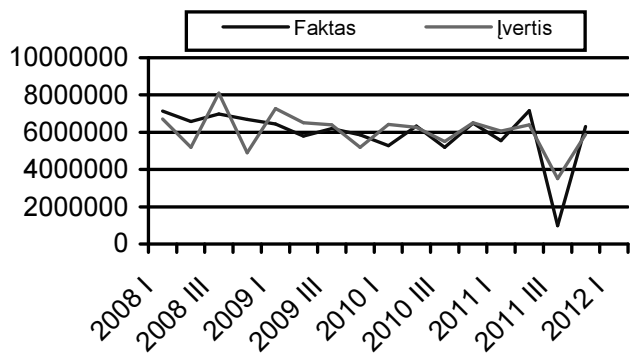

3.25 pav. Nacionalinio biudžeto pajamų modeliavimo rezultatai

Fig. 3.25. Results of modelling of the national budget revenue

Ivertinto modelio paklaida $-l=9,80 \%$; slenksčio kintamojo reikšmè $-r$ $=5523211,26$, o poslinkio parametras $d=1$.

Prekyba. Ivertintų namų ūkių vartojimo išlaidų modelio lygtis:

$$
V_{n}(t)=\underset{2,241}{33332,167} \underset{11,536}{1,049} V_{n}(t-1)-\underset{-3,847}{2,386} W(t-2)+\underset{2,880}{4,881} \cdot X_{10}(t-2) .
$$

Čia $V_{n}$ - namų ūkių vartojimo išlaidos, $W$ - vidutinis mėnesinis bruto darbo užmokestis, $X_{10}$-darbo pajamos iš užsienio.

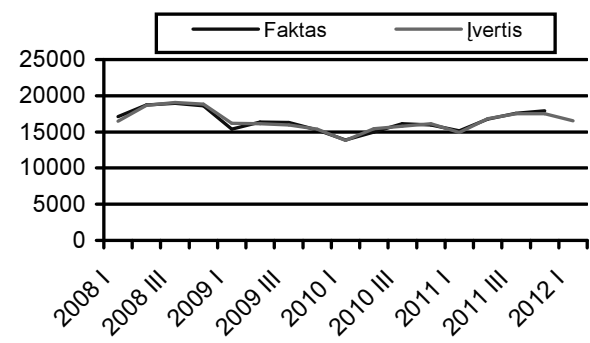

3.26 pav. Namų ūkių vartojimo išlaidų modeliavimo rezultatai

Fig. 3.26. Results of modelling of the household consumption expenditure

Ivertinto modelio paklaida $-l=1,69 \%$; determinacijos koeficientas rodo aukštą modelio adekvatumą $-R^{2}=0,90$, o Durbin-Watson statistika parodo, kad gauto modelio paklaidos nèra autokorteliuotos $D W=1,53$. 


$$
V_{v}(t)=\underset{1,371}{782,678}+\underset{6,704}{3,704 \cdot 10^{4}} B(t-3)+\underset{3,574}{0,172} P B(t-1) .
$$

Čia $V_{v}$ - valdžios sektoriaus vartojimo išlaidos, $B$ - nacionalinio biudžeto pajamos, $P B$ - pinigu bazè.

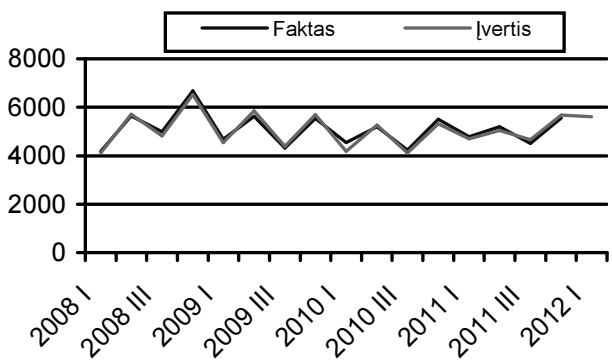

3.27 pav. Valdžios sektoriaus vartojimo išlaidų modeliavimo rezultatai

Fig. 3.27. Results of modelling of the general government consumption expenditure

Ivertinto modelio paklaida $-l=3,07 \%$; determinacijos koeficientas rodo aukštą modelio adekvatumą $-R^{2}=0,81$, o Durbin-Watson statistika parodo, kad gauto modelio paklaidos nèra autokorteliuotos $D W=1,81$.

$$
X_{3}(t)=\left\{\begin{array}{c}
2,951 \cdot X_{3}^{0,927}(t-1) \\
1,539 \quad 19,138 \\
17,951 \cdot X_{3}^{1,450}(t-1) \cdot X_{3}^{-0,639}(t-2) \\
2,875 \\
8,608
\end{array} .\right.
$$

Čia $X_{3}$ - materialinès investicijos.

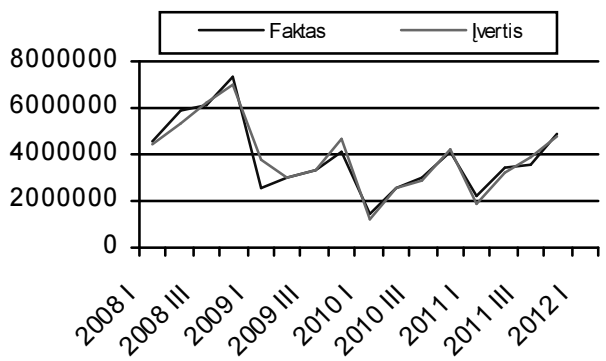

3.28 pav. Materialinių investicijų modeliavimo rezultatai

Fig. 3.28. Results of modelling of the investment in tangible fixed assets

Ivertinto modelio paklaida $-l=5,88 \%$; slenksčio kintamojo reikšmé $-r$ $=2884522,69$, o poslinkio parametras $d=1$. 


$$
I M(t)=\underset{1,627}{4,082 \cdot 10^{6}}-\underset{-11,893}{2141,893} V_{n}(t-4)+\underset{4,373}{3543,818} V_{v}(t-1)+\underset{11,818}{0,844} X_{4}(t-1) .(3.62)
$$

Čia $I M$ - importas, $V_{n}$ - namų ūkių vartojimo išlaidos, $V_{v}$ - valdžios sektoriaus vartojimo išlaidos, $X_{4}$ - tiesioginès užsienio investicijos.

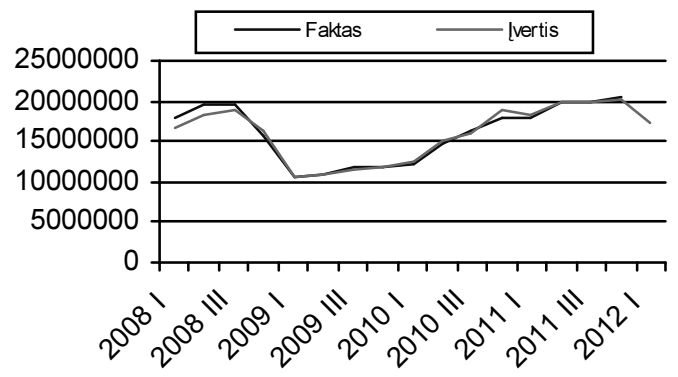

3.29 pav. Importo modeliavimo rezultatai

Fig. 3.29. Results of modelling of the import

Ivertinto modelio paklaida $-l=2,16 \%$; determinacijos koeficientas rodo aukštą modelio adekvatumą $-R^{2}=0,95$, o Durbin-Watson statistika parodo, kad gauto modelio paklaidos nèra autokorteliuotos $D W=1,71$.

$$
E X(t)=\underset{3,420}{1,410 \cdot 10^{8}}-\underset{-3,759}{2790,211} V_{v}(t-1)+\underset{9,016}{2,428 \cdot 10^{5}} P_{\text {exp }}(t-1)-\underset{-3,558}{2,910 \cdot 10^{7}} \bar{\xi}_{L V}(t-3) .(3.6
$$

Čia $E X$ - prekių ir paslaugų eksportas, $V_{v}$ - valdžios sektoriaus vartojimo išlaidos, $P_{\exp }$ - eksporto kainų indeksas, $\bar{\xi}_{L V}$ - lito ir Latvijos lato santykis.

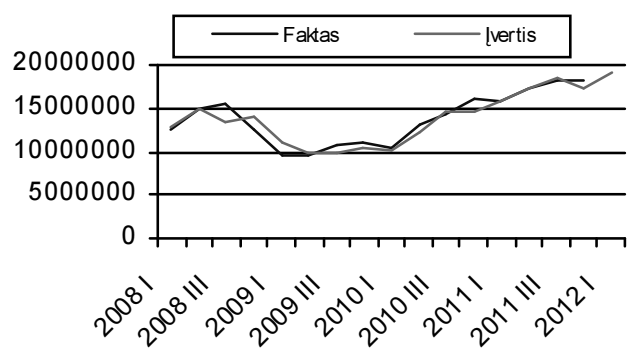

3.30 pav. Eksporto modeliavimo rezultatai

Fig. 3.30. Results of modelling of the export

Ivertinto modelio paklaida $-l=4,59 \%$; determinacijos koeficientas rodo aukštą modelio adekvatumą $-R^{2}=0,97$ o Durbin-Watson statistika parodo, kad gauto modelio paklaidos nèra autokorteliuotos $D W=1,94$. 


\subsection{Siūlomos metodikos ir klasikinių modeliavimo metodu palyginimas}

Vienas iš disertacinio darbo uždavinių buvo ịvertinti teikiamos metodikos naudą sukurtų ekonominių indikatorių modelio lygčių bei apskaičiuotų prognozių tikslumui padidinti.

Atlikus Lietuvos makroekonominių, verslo statistikos, finansinių indikatorių laiko eilučių grafinę, koreliacinę, regresinę (naudojant kategorinius kintamuosius), spektrinę bei laiko eilučių analizes, nustatyta, kad daugumos Lietuvos ekonominių indikatorių sezoniniai svyravimai pakankamai reikšmingi, taip pat yra nemažas kiekis išsiskiriančių reikšmių. Analizuotos ekonominių indikatorių laiko eilutès buvo modeliuotas taikant disertaciniame darbe teikiamą metodiką ir paraleliai - taikant iprastus laiko eilučių modeliavimo metodus.

Disertaciniame darbe teikiamas metodas leido sumažinti ekonominių indikatorių modeliu paklaidas ir taip pagerinti sudaromu modelių ir apskaičiuojamų prognozių tikslumą bei tvarumą. Gauti modelių paklaidų rezultatai pateikti 3.3 lentelèje.

Pagal ivertintas modelio lygtis apskaičiuojamos trumpalaikès prognozès. Apskaičiuotos pagrindinių indikatorių prognozių santykinès absoliutinès paklaidos pateiktos 3.2 lentelèje.

3.2 lentelè. Pagrindinių modelio indikatorių santykinès absoliutinès prognozès paklaidos, proc.

Table 3.2. Relative absolute errors of main model indicators forecasts, pct.

\begin{tabular}{|c|c|c|c|c|c|c|c|c|}
\hline Paklaida & $X_{2}$ & $X_{1}$ & $Y$ & $P_{G}$ & $P_{V}$ & $W$ & $B$ & $D$ \\
\hline $\begin{array}{l}\text { Vidutinè } \\
\text { santykinè } \\
\text { absoliutine } \\
\text { paklaida }\end{array}$ & 0,16 & 1,02 & 3,50 & 1,09 & 0,65 & 4,09 & 7,15 & 6,86 \\
\hline
\end{tabular}




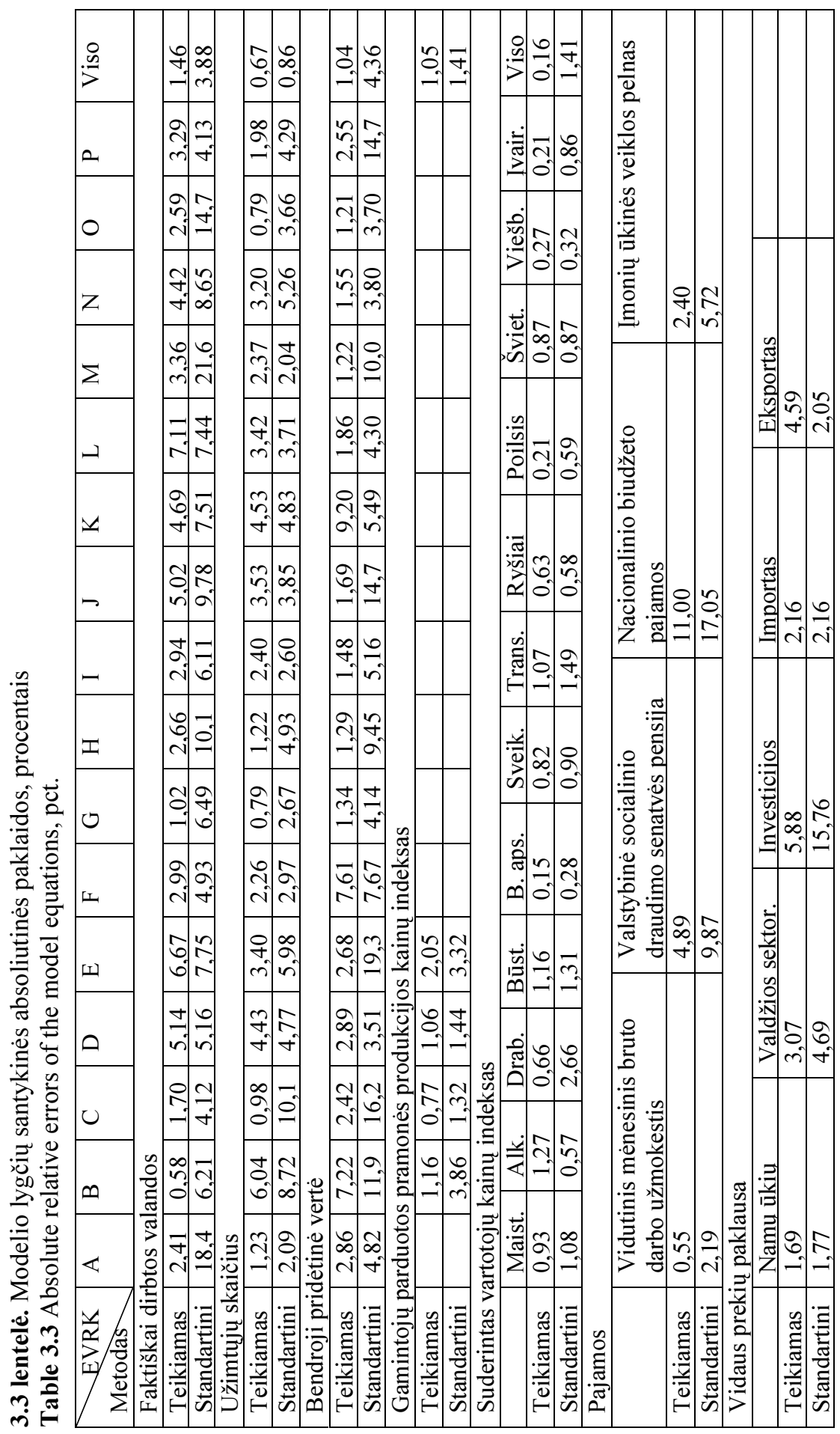




\subsection{Priemonès šalies ūkio pokyčių analizei}

Vienas iš šiame darbe iškeltų tikslų buvo sukurti programines priemones, kurios, naudojant pirmines prielaidas, leistu vertinti šalies ekonomikos tendencijas ir apskaičiuoti vedančiujų ekonominių indikatorių prognozes. Todèl buvo sukurtos dvi programinès priemonès, kurios realizuotos MSExcel pagalba:

- ekonominių indikatorių kitimo itakos Lietuvos ekonomikos būsenos ir perspektyvos (SARv2.0.XLS),

- ekonominių indikatorių trumpalaikių ir vidutinio ilgumo prognozių skaičiavimui (LMRM).

SARv2.0.XLS - programinè priemonè, skirta konkrečiu prekių ar paslaugų grupių kainų pokyčių pirminių poveikių suderintam vartotojų kainų indeksui vertinimui. Trumpu laikotarpiu, infliaciją nulemiančius veiksnius galima suskirstyti i paklausos ir sąnaudu grupes. Todèl, kainų pokyčiu įtakos analizei, integruota Lietuvos statistikos departamento sudaryta sąnaudu-produkcijos lentelè. Šioje lentelèje parodomas, prekių ir paslaugu vartojimas (pagal ekonominès veiklos rūšis), galutinis vartojimas, bendrasis kapitalo formavimas ir eksportas. Naudojantis sąnaudų - produkcijos lentelès duomenimis buvo nustatytos 61 sąnaudų grupès, kurios gali įtakoti bendrą šalies kainų lygi.

SARv2.0.XLS programinès priemonès pagalba nesudètingai ìvertinamas ¡vairių sąnaudų kainų pokyčių poveikis galutinio vartojimo kainoms, nustatomi atskirų vartojimo prekių ir paslaugų grupių ir bendro SVKI galutiniai pokyčiai. Priemoné sukurta pirminei ir antrinei žaliavų, gamybos, naftos produktuc, komunalinių paslaugų prekybos, transporto, ryšių ir kitų sąnaudų kainų pokyčių itakai maisto produktu ir nealkoholiniu gèrimų, alkoholinių gerimų ir tabako gaminių, drabužių ir avalynès, būsto, vandens, elektros, dujų ir kito kuro, būsto apstatymo, namų ūkio irangos ir kasdieninès priežiūros, sveikatos, transporto, ryšių, poilsio ir kultūros, švietimo, restoranų ir viešbučių, ivairių prekių ir paslaugų SVKI grupėms vertinti.

Naudojant SARv2.0.XLS galima nesudetingai i̇vertinti kokią pirminę ir antrinę itaką turès visam SVKI ir/ar atskiroms grupėms pavyzdžiui, kylančios kuro kainos, brangstanti elektra, dujos ar žemès ūkio produkcija.

Kainų pokyčių itaka vertinama naudojant konkrečios ekonominės veiklos rūšies sąnaudų svorius, kurie apskaičiuoti pagal, Lietuvos Statistikos Departamente sudarytą sąnaudų - produkcijos lentelę. SVKI apskaičiuojamas naudojant svertini agregavima. 


$$
Y(t)=\sum_{k=1}^{12} \sum_{i} \frac{x_{i j}}{\sum_{j} x_{i j}} I_{i} w_{k}
$$

Čia $x_{i j}$-j-tosios veiklos sąnaudos $i$-tojoje veikloje, $I_{i}-$ sąnaudų $i$-tojoje veikloje kainų indeksas, $w_{k}-$ SVKI prekių ir paslaugu grupès svoris.

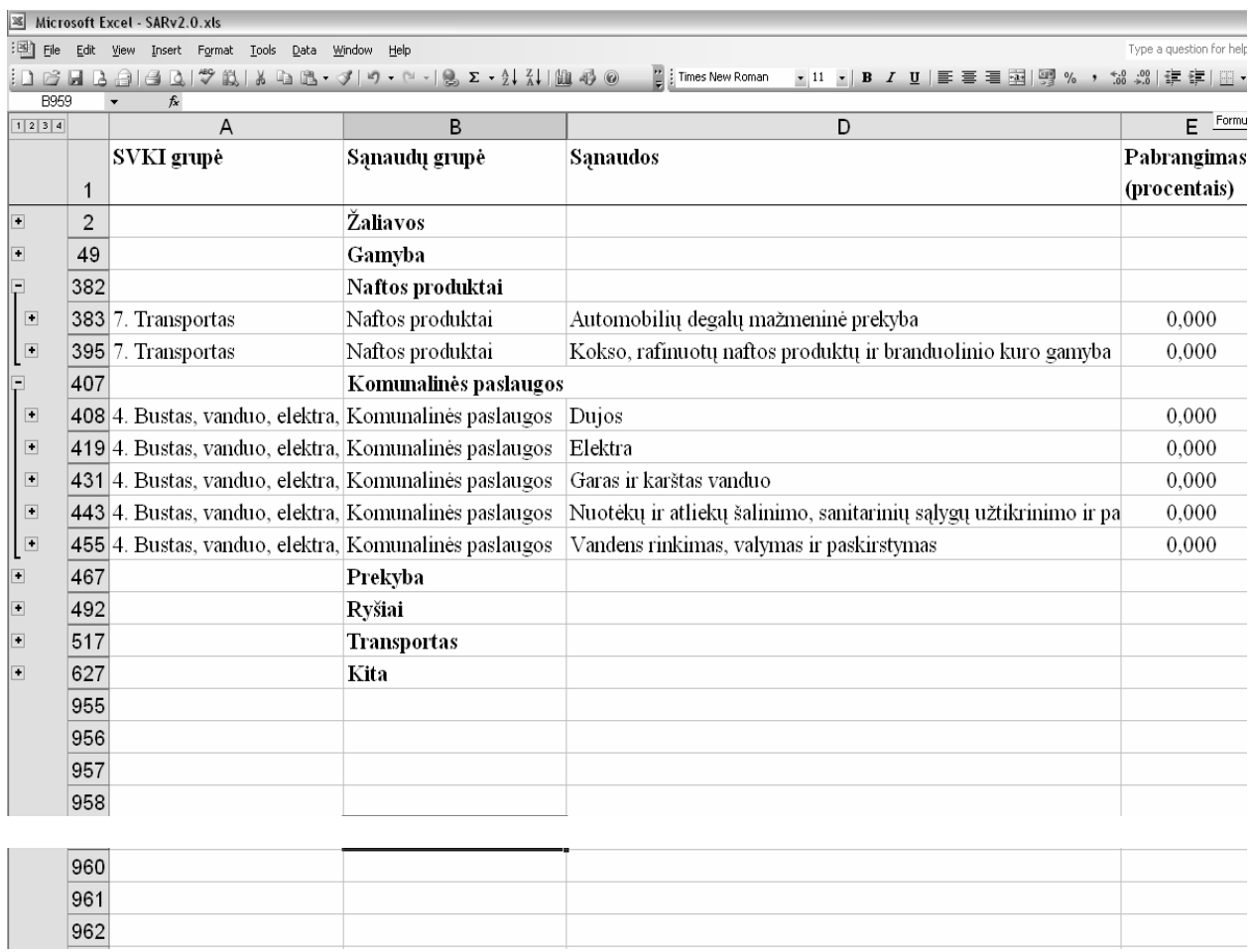

3.31 pav. Ekonominių indikatorių kitimo itakos programinè priemonè Fig. 3.31. Application window for estimation of the economic indicators changes

Programinè priemonè LMRM sukurta šalies ekonomikos tendencijų ir ekonominių indikatorių visumos vienalaikiam prognozių vertinimui, skirtingų scenarijų kūrimui. Trumpalaikes prognozes galima apskaičiuoti naudojant pirmines prielaidas arba be jų. 


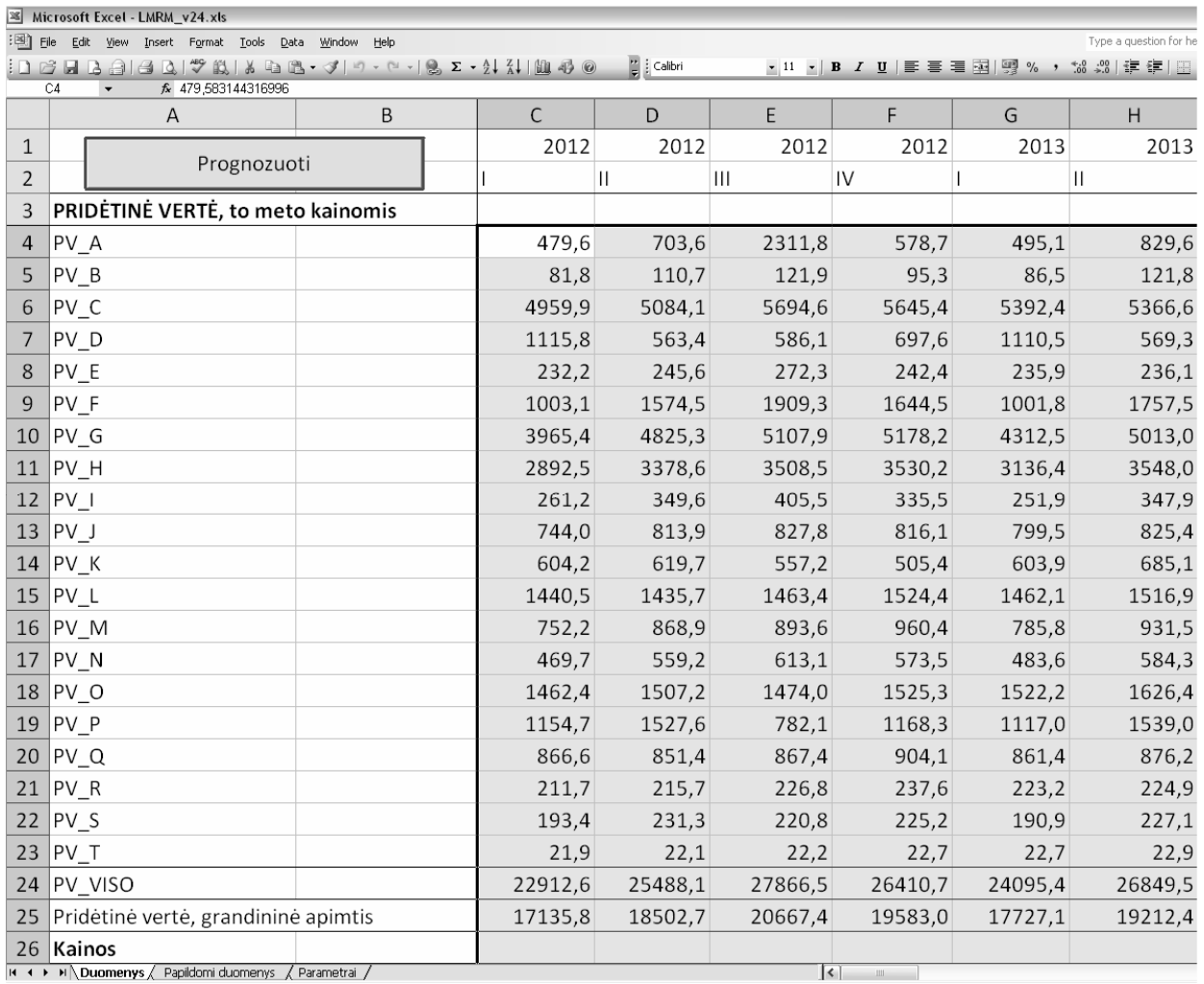

3.32 pav. Ekonominių indikatorių trumpalaikių ir vidutinio ilgumo prognozių vertinimo programinè priemonè

Fig. 3.32. Application window of estimation of the short-term and medium-term forecasts of the economic indicators

Naudojant programinę priemonę LMRM prognozuojami šie ekonominiai indikatoriai:

- Bendroji pridètinè vertè, to meto kainomis, pagal EVRK 21 veiklą;

- Bendrosios pridètinès vertès grandininè apimtis;

- Gamintojų parduotos pramonès produkcijos indeksas, pagal EVRK;

- Suderintas vartotoju kainų indeksas, pagal 12 vartojimo prekių ir paslaugu grupių;

- Importo kainų indeksas;

- Eksporto kainų indeksas;

- Namų ūkių vartojimo išlaidos;

- Valdžios sektoriaus vartojimo išlaidos; 
- Materialinès investicijos;

- Importas;

- Eksportas;

- Užimtumas, dirbtomis valandomis (vidaus koncepcija), pagal EVRK 21 veikla;

- Užimtumas (vidaus koncepcija), pagal EVRK 21 veiklą;

- Vidutinis mėnesinis darbo užmokestis;

- Valstybinè socialinio draudimo vidutinè mènesinè senatvès pensija;

- Imonių pardavimo pajamos;

- Nacionalinio biudžeto pajamos;

- Tiesioginès užsienio investicijos.

Ivedus turimus ekonominių indikatorių duomenis ar prielaidas ir pažymejjus indikatorius ir laikotarpius, kuriems norime apskaičiuoti prognozes reikia paleisti programos vykdyma, mygtuko „Prognozuoti“ pagalba (3.6 pav.). Paspaudus, aktyvuojasi makrokomanda, kuri pateiks pasirinktų ekonominių indikatoriu prognozes. Vèliau ivertintas prognozes galima išsaugoti, o esant poreikiui ar atsiradus naujoms atitinkamų indikatorių reikšmėms ar prielaidoms, prognozes galima ištrinti arba pakeisti.

\subsection{Trečiojo skyriaus išvados}

1. Norint patikrinti darbe pateiktų siūlymų praktini pritaikyma, buvo atlikti empiriniai tyrimai Lietuvos atveju. Skyriuje pateikti šalies pagrindinių ekonominių indikatorių praktinio modeliavimo, pagal antrame skyriuje aprašytą metodiką, rezultatai. Praktiniai rezultatai parode, kad siūloma metodika leidžia pakankamai tiksliai vertinti šalies ekonominius procesus, nes gauta vidutine santykine absoliutine paklaida 2,7 proc. Todèl metodiką tikslinga taikyti šalies ekonomikos būsenos ir perspektyvos modeliavimui, analizavimui bei savalaikiam prognozių skaičiavimui.

2. Nedidelès paklaidos (vidutinè modelio lygčiu paklaida lygi 2,7 proc., ekonominès perspektyvos - 3,1 proc.) irodo, kad sukurtas šalies ekonomikos indikatorių dinamikos modelis gali būti taikomas patikimai šalies ekonominei būklei tirti ir vertinti, kiekybinei ekonominių indikatorių analizei atlikti, tolesnei ekonomikos perspektyvai prognozuoti.

3. Modeliuojant Lietuvos gamybos indikatorius, naudojant gamybos funkcijos veiksnius, ne visoms ekonominèms veiklos rūšims pavyksta gauti patikimus rezultatus - paklaidos atskirose ekonominèse veiklose siekia 10 proc. Tai gali sąlygoti nepakankama statistinè informacija matuojanti ekonominius procesus bei kiti Lietuvos ekonomikos ypatumai. Itraukiant i gamybos 
funkciją papildomus regresorius gautos modelio lygtys pakankamai tiksliai aprašo (vidutinè santykinè absoliutinè paklaida lygi 1 proc.) pridètinès vertès empirinius duomenis bei pagerina prognozių tikslumą.

4. Sukurtos originalios programinès priemonès šalies ūkio pokyčių analizei atlikti leidžia nustatyti pagrindinių ekonominių indikatorių pokyčius, priklausomai nuo juos sąlygojančių pokyčiuc, rengti šalies ekonominių procesų prognozes, kurti priklausančius nuo pirminių prielaidų scenarijus. 


\section{Bendrosios išvados}

1. Išanalizavus teorines ir praktines šalies pagrindinių ekonomikos indikatorių modeliavimo prielaidas bei galimybes, modeliavimo patirti kitose šalyse bei Lietuvoje, nustatyta, kad esamus ekonominius modelius galima taikyti tik fragmentiškai. Daugumos modelių taikymas apribotas aktualumo bei aprèpties. Išsamiai vienalaikei šalies ūkio analizei bei ekonomikos perspektyvos vertinimui reikalingas ekonominis modelis, atitinkantis dabartinę ekonominę situaciją bei aprèpiantis visus šalies ūkio sektorius.

2. Sukurtas modelis, sudarytas iš penkių dalių: gamybos, kainų, prekybos, pajamų, bei užimtumo, apima pagrindinius šalies ekonomikos indikatorius. Modelis gali būti taikomas kompleksiniam šalies ekonomikos būklès tyrimui, kiekybinei ekonominių indikatorių analizei, ekonomikos perspektyvos vertinimui.

3. Ivairūs ekonominiai, demografiniai, socialiniai, politiniai, bei kalendoriniai pokyčiai reikšmingai ittakoja daugelio šalies ekonominių indikatorių laiko eilučių struktūrą - atsiranda pastovūs ir atsitiktiniai svyravimai, išskirtys, struktūriniai lūžiai. Atlikus pirminę pagrindinių ekonomikos indikatorių laiko eilučių analizę, buvo nustatyta, kad daugeli šalies ekonominių eilučių reikšmingai itakoja sezoniškumas bei įvairios trukdančios komponentès adityvios išskirtys, praeinantys pokyčiai, lygio postūmiai, reikšminga kalendoriaus itaka. Kai kuriose laiko eilutèse stebima dispersijos 
priklausomybè nuo laiko ir netiesinè elgsena. Todèl iprasti tiesiniai laiko eilučių vertinimo metodai tokių laiko eilučių modeliavimui nėra tinkami.

4. Ekonominių indikatorių modeliavimo metodų lyginamosios analizès rezultatai, naudojant modeliuotas ir realais ekonominiu indikatoriu laiko eilutes, igalino pasiūlyti naujus šalies tipinių bei sudètingos prigimties ekonominių indikatorių vertinimo ir prognozavimo metodus, kurie leidžia operatyviai apskaičiuoti trumpalaikę ir vidutinio laikotarpio ekonomikos indikatorių perspektyva, atlikti šalies ūkio kompleksinę analizę, analizuoti ivairių ekonominių indikatorių pokyčių poveiki ir pasekmes šalies ekonominei būsenai ir perspektyvai, kurti skirtingus ekonominius scenarijus.

5. Atlikti tyrimai bei modeliavimo rezultatai parodè, kad disertacijoje teikiama modeliavimo metodika leidžia tiksliau vertinti šalyje vykstančius ekonomikos procesus, o vertinimo tikslumą irodo sumažèjusios šalies ekonomikos indikatorių modelio lygčių paklaidos (modelio paklaida vidutiniškai sumažèjo nuo 6,0 proc. iki 2,7 proc.) bei žema vidutinè perspektyvos paklaida, kuri lygi 3 proc.

6. Sukurtos programinès priemonès leidžia kompleksiškai analizuoti šalies ūkio pagrindinių ekonomikos indikatorių pokyčius, ivvertinti trumpalaikes ir vidutinio laikotarpio prognozes, kurti skirtingus ekonominius scenarijus, priklausančius nuo ekonominių prielaidų. 


\section{Literatūra ir šaltiniai}

Adamopoulos, A. 2010. Stock Market and Economic Growth: En Empirical Analysis for Germany, Business and Economics Journal BEH-1:1-12.

Aivazian, S. A. 2001.Essentials of Econmetrics. Volume 2. Moscow: Unity, 432 p.

Aly, H.Y. 2008. The role of government in a market economy. [žiureta 2014 m. sausio 6 d.]. Prieiga per interneta:

$<$ http://econ.ohio-state.edu/Aly/docs/The\%20role\%20of\%20government $\% 20$ MS\%20Article\%209-27-08.pdf $>$

An, S.; Schorfheise, F. 2007. Bayesian Analysis of DSGE Models, Econometric Review, Taylor and Francis Journals, vol. 26(2-4): 113-172.

Arrow, K. J.; Chenery, H. B.; Minhas, B. S.; Solow, R.M. 1961. Capital-labour substitution and economic efficiency, Review of Economics and Statistics 43: 225-250.

Arrow, K. J.; Debreu, G. 1954. Existence of an Equilibrium for a Competitive Economy, Econometrica, vol. 22, No.3: 256-290.

Arvanitis, S.; Loukis, E. N. 2009. Information and Communication Technologies, Human Capital, Workplace Organization and Labour Productivity: A Comparative Study Based on rm-level Data for Greece and Switzerland, Information Economics and Policy, 20/1: 43-61.

Avdejenkova V. Bendrojo vidaus produkto modeliavimas. Daktaro disertacija, Vilnius, 2003, 148 p. 
Azavedo J. V. 2007. Interpretation of the Effects of Filtering Integrated Time Series. MPRA Paper No 6574. [žiurèta 2012 m. rugsèjo 15 d.]. Prieiga per internetą: http://mpra.ub.uni-muenchen.de/6574/

Bachmann, R.; Jinjui H. Bai. 2013. Public consumption over the business cycle. Quantitative Economics 4/3: 417-451.

Bai, J.; P. Perron. 1998. Estimating and testing linear models with multiple structural changes, Econometrica 66: 47-78.

Basdevant, O.; Kaasik, U. 2002. The Core of a Macro-econometric model for Estonia. Tallinn, 1-49.

Blanchard, O. J.; Quah, D. 1989. The Dynamic Effects of Aggregate Demand and Supply Disturbances, American Economic Association, vol. 79(4): 655-673.

Boldin, M.D. 1992. Using switching models to study business cycle asymmetries: Overview of methodology and application, Research Paper no 9211, Federal Reserve Bank of New Yourk.

Brockwell, P. Davis R. 1991.Time Series-Theory and Methods. New York.

Bruno, M.; Easterly, W. 1998. Inflation Crises and Long-Run Growth, Journal of Monetary Economics, 41: 3-26.

Budrytè, A.; Kvedaras, V. 2000. Lietuvos makroekonometrinio modelio vizija. Pinigu studijos, 2000/1: 5-17.

Burgess, S.; Mawson, D. 2003. Aggregate Growth and the Efficiency of Labour Reallocation, CEP Discussion Papers CEPDP 0580.

Celov, D.; Andersen, F. M.; Vilkas, E.; Grinderslev, D. 2003. A Macro-Econometric Model for Lithuania LITMOD. 105 p. [žiurèta $2010 \mathrm{~m}$. vasario 10 d.]. Prieiga per interneta: http://www.ekm.lt/lt/strategija/doc/litmod2.pdf,

Chan, K.S. 1990. Testing for threshold autoregression, Ann. Sta., 18: 1886-1894.

Chang, F.; Fernandez, A. 2010. On the Sources of Aggregate Fluctuations in Emerging Economies, NBER Working Papers 15938, National Bureau of Economic Research.

Charemza W.; Makarova S.; Parkhomenko V. 2002. LAM modelling of East European economies: Methodology, EU accession and privatisation. Paper prepared for the EcoMod2002 conference on Policy Modelling, Brussels.

Chatffield, Ch. 2004. The Analysis of Time Series, USA.

Chen, X.; Maringer, D. 2011. Detecting time-variation in corporate bond index returns: A smooth transition regression model. Journal of Banking \& Finance 35/1: 95-103.

Chumcero, R. A.;Schmidt-Hebbel, K. 2004. General Equilibrium Models An Overview, Working Papers Central Bank of Chile 307, Central Bank of Chile. 
Culver, S.E.; D.H. Papell. 1997. Is there a unit root in the inflation rate? Evidence from sequential break and panel data methods, Journal of Applied Econometrics 12: 435-444.

Dacco, R.; Satchell, S. 1999. Why do regime - switching models forecast so badly? Journal of Forecasting, 18: 1-16.

Dagum, E. B. 1988. The X-11-ARIMA/88 Seasonal adjustment Method - Foundations and Yser's Manual. Statistics Canada.

Darby J.; Ireland J.; Leith C. 1999. Wren-Lewis S. COMPACT: a rational expectations, intertemporal model of the United Kingdom economy. Economic Modelling, 16: 1-52.

DeJong, D. N.; Dave, C. 2007. Structural Macroeconometrics, Princeton, N.J: Princeton University Press, $338 \mathrm{p}$.

Demertzis M.; Els P.; Peeters M. 2002. EUROMON: De Nederlandsche Bank's MultiCountry Model, p. 34.

Dijk D.; Siliverstovs B. 2003. Forecasting industrial production with linear, nonlinear, and structural change models. Economic Institute report EI 2003-16, JAV.

Economic models at the bank of England. 1999. Bank of England.

Emerson, J.; Chihwa K. 2006. Testing for structural change in panel data: GDP growth, consumption growth, and productivity growth. Economics Bulletin, Vol. 3, No. 14: 112.

European Central Bank. 2004. The new EU member states convergence and stability, Third ECB central banking conference.

Fernandez-Villaverde, J. 2010. The econometrics of DSGE models, Series, Spanish Economic Association. Vol. 1(1): 3-49.

Gomez,V.; Maravall, A. 1997. Program TRAMO and SEATS: Instructions for the User, Beta Version. Banco de Espana.

Feng, H.; Liu, J. A. 2002. SETAR Model for Canadian GDP: Non-linearities and Forecast Comparisons. Working Paper EWP 0206, University of Victoria.

Findley, D. F.; Monsell, B. C.; ir kt. 1998. New Capabilities and Methods of the X-12ARIMA Seasonal Adjustment Program. Journal of Business and Economic Statistics, 16.

Forteza, A.; Rama M. 2002. labour Market Rigidity and the Success of Economic Reforms across More Than One Hundred Counties. Washington: World Bank. P. 50.

Franses, P.H.; van Dijk, D. 2000. Non-Linear Time Series Models in Empirical Finance, Cambridge University press, Cambridge.

Francis, N.; Ramsey, V. 2004. The Source of Historical Economic Fluctuations: An Analysis using Long-Run Restrictions, NBER Chapters in: NBER International Seminar on Macroeconomics 2004: 17-73. 
Fry, R; Pagan, A. 2011. Sign Restrictions in Structural Vector Autoregression: A Critical review, Journal of Economic Literature, American Economic Association, vol. 49(4): 938-960.

Gilmore, A.; O'Donnell, A.; Carson, D.; Cummins, D. 2003. factors Influencing Foreign Girect Investment and International Joint Ventures - a Comparative Study of Nothern Ireland and Bahrain, International Marketing Review, 20(2):195-215.

Ginevičius, R.; Podvezko, V. 2009. Evaluating the Changes in Economic and Social development of Lithuanian Countries by Multiple Criteria Methods, Technological and Economic Development of Economy, 15(3): 418-438.

Greenwood, J.; Jovanovic, H. 1990. Financial Development, Growth and the distribution of Income, Journal of Political Economy, 98:1076-1107.

Gregorio, D.J.; Guidotti, P.E. 1995. Financial Development and Economic Growth, World Development, 23(3): 433-448.

Gruss, B.; Mertens, K. 2009. Regime Switching Interest Rates and Fluctuations in Emerging Markets, Economics Working Papers ECC2009/22, European University Institute.

Gust, C.; Marquwz, J. 2004 International Comparison of Productivity Growth: the Role of Information Technology and Regulatory Practices, Labour Economics, 11: 33-58.

Hagen, J.; Traisttaru-Siedschlag, I. 2006. Macroeconomic Adjustment in the New EU Member States, SUERF Studies, The European Money and Finance Forum, 2006/4.

Hansen, E.H. 1999. Testing for linearity. Journal of Economic Surveys, 13(5):551-575.

Heijdra, J.; Ploeg, F. 2002: Foundations of modern macroeconomics // New York.

Intrilogator, M.D. 1983. Economic and econometric models, Handbook of Econometrics. Elsevier, edition 1, volume1, chapter 3, p. 181-221.

Yang, W. K.; Dongkoo, Ch., Geung-Hee, L. 1998. A Macroeconometric Model of the Korean Economy. Economic Papers, 1: 1-72.

Jakaitienè, A.; Kalinauskas, Ž. 2003. Lietuvos ekonomikos augimo prognozavimas trumpu laikotarpiu. Pinigu studijos, 2003/3: 79-100.

Johnson, R. 2001. Fiscal Reaction Rules in Numerical Macro Models. Research Division Paper of Federal Reserve Bank of Kansas City, 01-01: 1-38.

Josifidis ,K.; Allegret, J. P.; Gimet, C., Beke, E. 2013. The impact of excess reserves beyond precautionary levels on Bank Lending Channels in China. Journal of International Financial Markets, Institutions and Money 26: 358-377,

Jurgutytè, J. 2006. Lithuania's Track to the Euro and the Endogenity Hypothesis, Baltic journal of Economics, vol. 6, 1: 53-70.

Kalinauskas, Ž.; Tamošiūnas, R. 2000. Lietuvos ekonomikos taikomasis bendrosios ekonominès pusiausvyros modelis. Pinigu studijos, 1: 40-62. 
Kaminskienè, B.; Avdejenkova,V. 2003. Bendrojo vidaus produkto išankstinis vertinimas. Pinigu studijos, 2003/3: 14-34.

Karpavičius, S. 2006. Emigracijos poveikis Lietuvos ekonomikai. Pinigu studijos, 2006/2: 21-40.

Karpaičius, S, 2008. Kalibruotas Lietuvos ekonomikos dinaminis stochastinis bendrosios pusiausvyros modelis, Pinigu studijos, 2/2008: 22-46

Keynes, J. M. 1936. The general theory of employment, interest and money. London: Macmillan.

King, R. G.; Plosser, C. I.; Stock, J. H.; Watson, M. W. 1991. Stochastic trends and Economic Fluctuations, American Economic Review, American Economic Association, vol. 81(4): 819-840.

Kydland, F. E.; Prescott, E. C. 1982. Time to Build and Aggregate Fluctuations, Econometriva, Econometric Society, vol. 50(6): 1345-1370.

Kuodis R.; Vetlov I. 2002. Pinigu politikos poveikio mechanizmas Lietuvoje. Pinigu studijos, 2002/3: 27-63.

Kuodis, R.; Mačiulis, N. 2005. Valiutų krizių prognozavimas: teoriniai ir praktiniai aspektai, Pinigu studijos, 2005/1.

Kvedaras, V. 2004. Integracijos i Europos Sajunga pasekmiu Lietuvos ūkiui makroekonometrinis modeliavimas. Daktaro disertacija, Vilnius, 137 p.

Kvedaras, V.; Rudzkis, R. 2000. Lietuvos eksporto matematinis modeliavimas ir prognozavimas. Lietuvos matematikos rinkinys, T. 4 (spec. numeris), Vilnius: MII, 2000: 296-303.

Ladiray D., Quenneville B. 2001. Seasonal Adjustment with the X-11 Method, Lecture Notes in Statistics, New York.

Lietuvos ekonomikos matematiniai modeliai ekonomikos procesams prognozuoti (LEMM). 2003. Projektas konkursui pagal programą „Prioritetinès Lietuvos moksliniu tyrimu ir eksperimentinès plètros kryptys“. Vilniaus universitetas, Matematikos ir informatikos institutas, Ekonomikos institutas.

Lietuvos ekonomikos matematiniai modeliai makroekonominiams procesams prognozuoti (LEMM). Ataskaita. 2004. Vilniaus universitetas, Matematikos ir informatikos institutas, Ekonomikos institutas.

Lietuvos ekonomikos matematiniai modeliai makroekonominiams procesams prognozuoti (LEMM). Metinè ataskaita. 2005. Vilniaus universitetas, Matematikos ir informatikos institutas, Ekonomikos institutas.

Lietuvos ekonomikos matematiniai modeliai makroekonominiams procesams prognozuoti (LEMM). 2006 metų galutinė ataskaita. 2006. Vilniaus universitetas, Matematikos ir informatikos institutas, Ekonomikos institutas. 
Levine P.; Pearlman, J.; Perendia, G.; Yang, B. 2010, Endogenous Persistence in a Estimated DSGE Model under Imperfect Information, Discussion Papers in Economics, $03 / 10$.

Lothian J., Morry M. 1978. A Set of Quality Control Statistics for the X-11-ARIMA Seasonal Adjustment Method, Working Paper 78-10-005, Methodology Branch, Statistics Canada, Ottawa ON, Canada.

Lucas, R. E. 2003 Macroeconomic Priorities, American Economic Review, American Economic Association, vol. 93(1): 1-14.

Maravall, A. 2007. Large Scale Applied Time Series Analysis with Program TSW (TRAMO-SEATS for Windows). Federal Committee on Statistical Methodology Research Conference.

Marcellino, M. 2002. Forecasting EMU macroeconomic variables IGIER Working Paper No. 3312, Italy.

Martinez, V.; Sanchez-Robles, B. 2012. Macroeconomic Stability and Growth in Eastern Europe, Macroeconomics and Beyond: Essays in Honour of Wim Meeusen. Belgium:Maklu. p. 310

Musgrave, J.C. 1964. A set of end weights to end all end weights. Working paper, Bureau of Census.

Perron, P.; Qu, Z. 2005. Estimating and Testing Structural Changes in Multivariate Regressions.

Proškutè A. 2012. Drivers of the Business cycle in Lithuania. Pinigu studijos, 2012/1: 527.

Proškutè, A. 2012. Causes and characteristics of business cycle in Lithuania: a structural var approach, Ekonomika, Nr. 91(1): 41-58.

Ramanauskas, T.; Jakaitienè, A. 2007. Namų ūkių vartojimo modeliavimas. Pinigu studijos, 2007/1: 25-44.

Rudzkis, R.; Vilutis, G. 1999. Makroekonometrinių svyravimų ekonometrinis modeliavimas. Pinigu studijos, 1999/2: 25-37.

Rudzkis, R.; Kvedaras, V. 2003. Lietuvos eksporto tendencijos ir ekonometriniai modeliai. Pinigu studijos, 2003/4: 29-51.

Rudzkis, R.; Kvedaras, V. 2005. A Small Macroeconometric Model of the Lithuanian Economy. Australian Journal of Statistics, 34/2: 185-197.

Shiskin, J.; Young, A. H.; Musgrave, J.C. 1967. The X-11 Variant of the Census Method II Seasonal adjustment program. Technical Paper No. 15, Bureau of Census.

Schmitt-Grohe, S.; Uribe, M. 2003. Closing small open economy models, Journal of International Economics, Elsevier, 61(1): 163-185. 
Smets F., Wouters, R. 2003. An Estimated Dynamic Stochastic General Equilibrium Model of the Euro Area, Journal of the European Economic Association, MIT Press, 1(5): 1123-1175.

Stankūnienè V. 1995. Ekonominio nuostolio dèl Lietuvos darbo rinkos pokyčių ivertinimas. Pinigu studijos, 1995/2: 30-45.

Tong, H. 1990. Non-Linear Time Series: A Dynamical Systems Approach Oxford: Oxford University Press.

Vetlov, I. 2000. Virbickas E. Lietuvos infliacijos inercijos analizè. Pinigu studijos, 2000/3: 5-16.

Vetlov, I. 2001. Lietuvos ekonomikos dolerizavimo ekonometrinè analizè. Pinigu studijos, 2001/3: 22-44.

Vetlov, I. 2002. Lietuvos kainų kitimas ir jo veiksniai. Pinigu studijos, 2002/2: 24-22

Vetlov, I. 2003. Baltijos šalių ekonomikos augimo apskaita. Pinigu studijos, 2003/3: 1434.

Vetlov, I. 2004. The Lithuanian block of the ECSB multi-country model. Bank of Finland BOFIT Discussion Papers, 2004/13, 61 p.

Vetlov, I. 2006. Lietuvos darbo rinkos lankstumas. Pinigų studijos, 2006/1: 5-22.

Willman, A.; Kortelainen, M.; Mannisto, H. L.; Tujula, M. 1998. The BOF5 Macroeconomic Model of Finland. Structure and Equations. Bank of Finland discussion papers.

Willman, A.; Kortelainen, M.; Mannisto, H. L.; Tujula, M. 2000. The BOF5 macroeconomic model of Finland, structure and dynamic microfoundations. Economic Modelling, 17: 275-303. 



\section{Autorès mokslinių publikaciju disertacijos tema sąrašas}

\section{Straipsniai recenzuojamuose mokslo žurnaluose}

Bratčikovienè, N. 2012. Adapted SETAR model for Lithuanian HCPI time series, Nonlinear analysis: modelling and control. 17(1/2012): 27-46. ISSN 1392-5113. (ISI Web of Science)

Bratčikovienè, N. 2007. Changes in labour supply and demand in Lithuania. Social research. 1(9): 35-44. ISSN 1392-3110. (CEEOL, IndexCopernicus, EBSCO)

Bratčikovienè, N. 2005. Lietuvos gamybos rodiklių modeliavimas. Lietuvos matematikos rinkinys. 45, spec. nr. 2005: 400-403. ISSN 0132-2818. (CIS, MatSciNet, VINTI, Zentralblatt MATH)

Bratčikovienè, N. 2007. Šalies makroekonominių rodiklių modeliavimo ypatumai. Lietuvos matematikos rinkinys. T. 47, spec. nr.: 425-433. ISSN 01322818. (CIS, MatSciNet, VINTI, Zentralblatt MATH) 
Misiūnas, A.; Bratčikovienè, N. 2007. Pajamų nelygybè ir jų normalizavimas. Lietuvos statistikos darbai. 46: 112-121. ISSN 1392-642X.

Misiūnas, A.; Bratčikovienè, N. 2006. Migracijos tendencijos. Lietuvos statistikos darbai. 2: 16-22. ISSN 1392-642X.

\section{Straipsniai kituose recenzuojamuose mokslo leidiniuose}

Bratčikovienè, N. 2008. Ekonomikos perkaitimo veiksnių vertinimas Lietuvoje. Ekonomika ir vadyba - 2008 [Economics and management - 2008]. 2008: 453458. ISSN 1822-6515. (EBSCO)

Bratčikovienè, N. 2006. The influence of changes in model on seasonal adjusted data. Conference on seasonality, seasonal adjustment and their implications for short-term analysis and forecasting. 2006: 1-5.

Bratčikovienè, N. 2005. Vartojimo prekių ir paslaugų kainos Lietuvoje ir kitose Europos Sajungos šalyse. Ekonomika ir vadyba: aktualijos ir perspektyvos: Ernesto Galvanausko tarptautine moksline konferencija. 5: 42-47. ISSN 16489098 . 


\section{Summary in English}

\section{Introduction}

\section{Research problem}

The models of economic indicators are created for the analysis of national and international economic process, the evaluation of prospects, the analysis of sustainability, the investigation of reactions to certain economic impulses, the identification and calibration of the economic regularities and dependencies, the generation of the necessary information for forecasting and management and for the quantitative determination of decisions taken. Such models are based on econometric and/or balance equations and identities describing the global economic behaviour.

Many countries of the world use economic models for economic analysis of country, calculation of economic indicators forecasts, checking various economic scenarios. The modelling of economic indicators is particularly well-developed in the United States of America, United Kingdom, the Netherlands, and Scandinavian countries. The modelling of these countries' economies had been in progress for many years and since economic models are usually created for various purposes, some countries have several economic models.

Although, from the restoration of independence onwards, Lithuania may be historically considered as rather young economy state, but in this period witnessed many essential changes in the Lithuania's economy: Lithuania switched from planned to market economy, faced with hyperinflation and high unemployment. While moving towards sustainability, Lithuania's economy went through two economic crises, which 
made an adverse impact on its economic development. In view of rapidly changing economic conditions and growing demand for reliable forecasts for various indicators and research into the reaction of the national economy to certain economic changes, it makes sense to have a model of the country's economic indicators, which would help prepare reliable forecasts and enable the modelling of different economic behaviour scenarios, depending on different assumptions.

\section{Relevance of the thesis}

In Lithuania, the modelling of economic indicators has been developed for a long time; however, most of the previously conducted and publicly available studies into the Lithuanian economy were mainly dedicated to solving specific problems, and the previously developed models for the simultaneous broader economic analysis have not been updated, which - in view of the recent important economic events - made them no longer relevant and reliable. Therefore, there is a need for an economic model that would be relevant for the current economic situation, covering all branches of economy, which could be used for the studies into and assessment of the country's economic situation, quantitative analysis of the key economic indicators, further economic development forecasts, social and economic decision-making and different economic scenarios creation.

\section{Object of the research}

The doctoral thesis focuses on the country's macroeconomic (national accounts, general government finance, investment, price, foreign trade), business (enterprise, industry, construction, domestic trade) and social statistics time series, analyses mathematical models and methods allowing a rather accurate description and forecasts of the behaviour of economic indicators time series and generate the information needed to increase economic efficiency.

\section{Aim of the thesis}

The aim of the thesis is to create the model of the country's economic measuring indicators dynamics, that can be used for comprehensive investigation and evaluation of adequacy, consistency and links between economic indicators, analyse the possibilities and prospects of modelling the national economy, to perform a comparative analysis of possible modelling methods, and to create - on its basis - a model of the leading economic indicators of the country's economy, which could be used for the studies into and assessment of the country's economic situation, quantitative analysis of the impact of changes in certain indicators on other indicators, production of forecasts for the key national economic indicators.

\section{Objectives of the thesis}

To achieve the aim of the thesis and solve the research problem, the following tasks were formulated in the thesis:

1. To analyse the experience of modelling the national economy in Lithuania and the possibility for the application of other countries' models and identify theoretical and 
practical assumptions for the modelling of the country's economic indicators dynamics model.

2. To determine the structure of and theoretical basis for the countries economic model being developed.

3. To perform a primary analysis of the economic indicators time series and determine their unobserved components.

4. To perform a comparative analysis of the economic indicators time series modelling methods, that provides the opportunity of more accurate estimation of typical and complex nature economic indicators time series.

5. To draw up model equation specifications, to estimate model equation parameters, and to study the accuracy and sustainability of models and forecasts.

6. To create tools for the complex evaluation of country's economic situation and prospects, the creation of economic scenario's, the impacts of changes in certain indicators on the county's economic status.

\section{Research methodology}

To achieve the aim of the thesis and solve the research problem, economic statistics and econometric theory was studied, the models used in Lithuania and other countries were analysed, a comparative analysis of time series modelling methods was performed, the newest theoretical time series analysis methods were analysed, and their practical application possibilities were determined.

\section{Scientific novelty of the thesis}

The scientific novelty of research is demonstrated by the following results:

1. A new methodology for the assessment and forecasting of country's economic indicators, enabling analysis of country's economic indicators relations and their identity of measured economic processes, the production of short-term and mediumterm forecasts for economic indicators, complex analysis of the economy, analysis of the impact of certain features and conditions on the national economy, was proposed.

2. The complex model of the key economic indicators was created, which allows the monitoring, analysing and forecasting the economic processes in the country as a whole and the separate components. The accuracy and sustainability of the model equations and forecasts were estimated. The stability of model parameters was examined.

3. It was proved that the use of the adapted SETAR model, discussed in the thesis, for the modelling of complex-nature time series results in better reflection of economic process that can be found from a smaller errors of model equations.

4. A comparative analysis of non-observed time series component estimation methods was performed using the modelled and real economic indicators sequences.

5. It was determined that the modelling of the individual components of the time series of the country's economic indicators by using methods described in thesis results in the improvement in the accuracy and sustainability of the forecasts.

6. Created software tools enabling: the complex evaluation of county's economic status and prospects, analysis of changes in the leading national economic 
indicators, production of forecasts, estimation of the impact of changes in the modelled indicators on related national economic indicators and assessment of the impact of economic indicators changes in the economy were developed.

\section{Practical value of research findings}

The thesis provides a methodology for the estimation and assessment of country's economic indicators, enabling the opportunity for more fully reflection of the existing economic processes and achievement of smaller model and forecast errors at the same time, improvement in the accuracy and sustainability of analysis and forecasts. This methodology is also suitable for the modelling of complex-nature time series, the modelling whereof with usual time series modelling methods does not yield desired results.

The research findings discussed in the thesis may be used for a reliable complex estimation and analysis of the key country's economic indicators, production of shortterm and medium-term forecasts, and creation of different scenarios.

\section{Statements to be defended}

1. In view of the peculiarities of the Lithuanian economy and the limitations imposed by them, the insufficient relevance and coverage of existing models, the application of other countries' economic models and those currently available in Lithuania and other countries for the analysis of the Lithuanian economy and production of forecasts for economic indicators is either not feasible or can be just fragmentary.

2. The structural analysis of the time series being modelled through the extraction of their non-observed components enables increase of the accuracy in description of ongoing economic processes and thereby a reduction in model and forecast errors.

3. The adapted SETAR method, proposed in the thesis for the modelling of unstable, complex-nature time series (with various breaks, outliers, variance changing in time), enables the creation of reliable economic indicators models, which can be used for analysis and forecasting.

4. The original software tools, developed by the author of the thesis, enable a complex and expeditious analysis of the key country economic indicators, estimation of their changes depending on the changes that caused them, construction of national economic scenarios, and preparation of reliable economic indicators forecasts.

\section{Approval of research findings}

Based on the thesis, nine scientific papers were published: six - in an academic periodical peer-reviewed journal, three - in other peer-reviewed publications. The course of work on and the findings of the thesis were presented at ten Lithuanian and international scientific conferences:

- 5th Ernestas Galvanauskas International Scientific Conference. 2005. Šiauliai, Lithuania;

- XLVI Scientific Conference of Lithuanian Mathematical Society. 2005. Vilnius, Lithuania; 
- International Scientific Conference „Conference on seasonality, seasonal adjustment and their implications for short-term analysis and forecasting". 2006. Luxembourg, Grand Duchy of Luxembourg;

- XLVII Scientific Conference of Lithuanian Mathematical Society. 2006. Kaunas, Lithuania;

- 7th Ernestas Galvanauskas International Scientific Conference. 2007. Šiauliai, Lithuania;

- XLVIII Scientific Conference of Lithuanian Mathematical Society. 2007. Vilnius, Lithuania;

- 12th International Scientific Conference „Mathematical Modelling and Analysis”. 2007. Trakai, Lithuania;

- International Scientific Conference „Nordic Conference on Mathematical Statistics". 2008. Vilnius, Lithuania;

- XLIX Scientific Conference of Lithuanian Mathematical Society.2008. Kaunas, Lithuania;

- 13th International Scientific Conference „Economics and Management” 2008. Kaunas, Lithuania.

\section{Structure of the thesis}

The thesis is comprised of an introduction, three chapters, general conclusions, references, a list of the author's publications on the subject of the thesis, six annexes, and a summary in English. The volume of the thesis - 130 pages (without annexes); the text of the thesis contains 137 formulas, 44 figures and 8 tables.

\section{Overview and purposes of econometric modelling}

The first models of econometric indicators date back to the end of the $19^{\text {th }}$-beginning of the $20^{\text {th }}$ century, when well-known economists Walras, Klein, Keynes et al. attempted to describe the economy through simultaneous equation systems. The ideas of those prominent economists served as a basis for the creation of quite a number of models in different countries.

The key advantage of the economic model, which came down to us, is the simultaneous analysis of the whole economy. A correct model of economic indicators not only reveals the interrelation and interdependence of markets but also guarantees the integrity and compatibility of forecasts.

Currently, the creation of models of economic indicators involves not only balance but also econometric equations. In the process of creating models, economics, econometrics and mathematical statistics are used. An econometric model connects the equations explaining economic indicators - to form a common, consistent system.

The meaning and importance of models is acknowledged in many countries of the world and by individual institutions, having long experience of creation and application 
of economic models. The World Bank suggested that economic models may be used in different spheres (A. Budraitytè, V. Kvedaras 2000):

1. Economic stability maintenance survey.

2. Assessment of the consequences of structural changes.

3. Analysis of the economic development strategy.

4. Quantitative assessment of political decisions under consideration and the results of those already made.

5. Domestic and foreign policy feasibility studies.

6. Assessment of the impact and costs of different economic policy scenarios.

Due to a wide range of possibilities for using the models of economic indicators, the need for econometric modelling became a particularly topical everyday phenomenon in solving various scientific problems, analysing the current situation, constructing various political, social and economic scenarios, and estimating forecasts for various indicators.

The first chapter of the thesis presents an overview on the economic model of the Bank of England, Austrian macroeconomic model LIMA, Nepal macro-econometric model, and economic modelling in Lithuania (Lithuanian macro-econometric model LITMOD, modelling of the Lithuanian gross domestic product in the thesis of V. Avdejenkova, macro-econometric modelling of the consequences of integration into the European Union for the Lithuanian economy in the thesis of V. Kvedaras, models of business cycles in the thesis of A. Proškute, and a project dedicated to the Lithuanian economic-mathematical models for forecasting economic processes).

Based on the results of the analysis performed, the following conclusions can be drawn:

1. Many countries and institutions of the world use the models of economic indicators for various purposes and tasks (assessment of economic stability, consequences of structural changes, economic development, quantitative evaluation of political decisions under consideration and those already made, suitability of domestic and foreign policies for achieving economic purposes, impact of different economic policy scenarios), therefore, the importance and relevance of such models is undoubted.

2. Economic model at the Bank of England, the Macroeconomic model LIMA for Austria, Nepal Macroeconomic Model and economic modelling experience in Lithuania and other economic models are briefly presented in first chapter of thesis. Plenty of economic models show that in order to obtain an adequate model for the country's economic processes requires detailed analysis of country's economical properties, identification of economical and mathematical assumptions, selection of leading economic indicators set and suitable modelling techniques.

3. The analysis of foreign countries' economic models showed that - due to the peculiarities of the Lithuanian economy and the limitations imposed by them - it is possible to use the models created by other countries in Lithuania just fragmentarily.

4. The analysis of the country's experience of modelling the economic indicators in Lithuania showed that most of the previously created models were dedicated for the modelling of the key indicators in very specific spheres or for the solving of very specific tasks and problems. 
5. The periodic updating of model equations parameters, taking into account the changes in the domestic economy and the environment, is necessary when country's economic development conditions are unstable and unsustainable.

\section{Anatomy of econometrics. Methods for the assessment of the model of economic indicators}

A reliable and consistent analysis of the national economy allows obtaining the overall picture of the development of the national economy, enables the assessment of the economic benefit of political and social decisions and production of forecasts. For this purpose, first of all, the main characteristics of the sectors of the national economy have to be established, the interrelation between the indicators in question has to be assessed, the possibilities, theoretical assumptions and implementation modes for their modelling have to be analysed. The thesis focuses on the problem of theoretical and practical possibilities for the modelling of country's economic indicators, methods for the production of reliable short-term forecasts, possibilities for the assessment of the structure and individual non-observed components of the time series of economic indicators, and the aspects of the accuracy of the model.

In this chapter, a brief description of the modelling methods used in the thesis is provided, the assumptions made are delineated. Assiduous attention is given to the structural analysis of the time series of economic indicators because, in the process of work, it was established that the estimation of individual non-observed components of time series results in a significant reduction in the overall model error.

To establish whether spectral analysis produces reliable results in determining the non-observed components of time series, modelled time series were used. 800 different modelled time series, imitating the behaviour of real economic indicators, were analysed. Since the time series were modelled from individual known components, all the deterministic non-observed components of the time series were known precisely. The final modelled time series were calculated using an additive model:

$$
y(t)=\sum_{i} U_{i}(t)=T(t)+S(t)+I R(t), T=1,2, \ldots, 64 .
$$

To check the statement about the reliability of spectral analysis in determining the non-observed components of time series, spectral function plots were generated for the modelled time series.

The peaks of the spectral function plots of all modelled time series, irrespective of the type of trend and seasonal component, were reached in three points: $\omega=0, \omega=\frac{\pi}{2}$ and $\omega=\pi$, which shows that the time series in question have a trend and a seasonal component whose peaks repeat twice a year. The results of the analysis prove the statement that spectral analysis produces reasonably accurate results in determining the non-observed components of a time series, irrespective of the type of trend, seasonality or fluctuations in its random component. Therefore, based on those results, a decision 
was made to perform a spectral analysis of all endogenous and exogenous indicators before forming equations for the model of the country's macroeconomic indicators.

In the course of the analysis of the real spectral functions of the time series of country's economic indicators, it was established that most of them have a significant seasonal component. After an in-depth analysis and comparison of the results of modelling against the actual ones, it was established that the modelling of individual components results in smaller model and forecast errors. Therefore, in the process of modelling the time series of individual indicators, the non-observed components of time series were extracted.

At the next stage of the study, efforts were made to establish which of the existing methods is the best for assessing the non-observed components of time series. For the comparison of such methods, modelled time series prepared for spectral analysis and additional time series, the variance of whose random component significantly changes in time, were used.

Since the non-observed components of the modelled time series are known precisely, for the comparison of the methods, the trend and seasonal component estimate model $y(t)=\hat{T}(t)+\hat{S}(t)+\varepsilon(t)$ and time series model $y(t)=\hat{T}(t)+\hat{S}(t)+\hat{I}(t)$ errors are estimated, where $\hat{T}(t)$ - trend estimate, $\hat{S}(t)$ - seasonal component estimate, $\hat{I}(t)$ random component estimate. For the comparison of results, the mean absolute percentage error (MAPE) and root mean square percentage error (RMSPE) were used.

The precision and suitability of the models was established not only according to MAPE and RMSPE but also by checking the autocorrelation and independence of residuals and their distribution according to the normality law and by calculating standard diagnostic statistics.

To perform the analysis, Demetra, TRAMO-SEATS software, approved by the Statistical Office of the European Union (Eurostat), NBBTools software, used by the National Bank of Belgium, and software developed by the author of the thesis were used.

The assessment of the non-observed components of the modelled time series showed that the results of the extraction of the non-observed components of time series obtained using both parametric and non-parametric methods are rather similar. The different forms of the trend function did not impact on the results obtained. As for the trend and seasonal component estimates, smaller mean errors were observed when the parametric method was used. Therefore, a conclusion can be drawn that the non-observed components of the time series the variance of whose random component does not significantly change in time are better estimated by parametric methods. The results of the analysis of the modelling of the time series the variance of whose random component does significantly change in time show that both errors (MAPE and RMSPE) of the time series models are smaller when the non-parametric method is used. However, since the difference in the errors is insignificant, both parametric and non-parametric methods may be used for the estimation of the non-observed components of time series.

In the process of forming the equations for the country's economic model, it was noticed that usual econometric mechanisms do not enable an accurate enough description of quite a number of time series. Therefore, new, more efficient methods 
have been searched for, which would enable the estimation of all key country's economic indicators with sufficient precision. On the basis of the studies done for the thesis and available scientific literature, a new method for the modelling of complexnature time series, to which traditional linear methods do not apply, was proposed - an adapted threshold autoregressive method.

In the thesis, an adapted SETAR model is provided and described. The model estimation algorithm enables the estimation of non-linear models through the assessment of the importance of the non-observed components of time series. The thesis presents an algorithm for the estimation of only a two-subclass adapted SETAR model; nevertheless, the methodology proposed may also be used for the estimation of models with more than two subclasses.

For the verification of the adapted SETAR method, real and modelled time series were used. The results of the adapted SETAR model estimates were compared against the results of the ARIMA model, which is most often used in time series analysis. The charts show that the adapted SETAR model describes data better than the ARIMA model; it is because the deviations of estimators from the true values in the adapted SETAR model are smaller than in the ARIMA model. For a more accurate comparison of the results obtained, the mean absolute percentage error of the models was calculated. The results are provided in Section 2.3.3 of the thesis.

The analysis of errors in the adapted SETAR model and in the ARIMA model showed that the adapted SETAR model is more stable because the error variance is considerably smaller. The charts of model errors are presented in Annex 5. The results of the study proved the statement that it makes sense to use the adapted SETAR method for the modelling of non-linear behaviour, complex structure time series or time series whose variance significantly changes in time.

The results of the studies conducted determined the choice of the methods and estimation algorithm used for the creation of the model of the key country's economic indicators.

First of all, using spectral analysis, non-observed components were determined and extracted for all the time series of the indicators in question. Then, it was attempted to figure out whether there are other economic indicators whose changes might explain the economic behaviour of the indicators in question and to prove this dependence using correlation matrices. When significant relations were detected, equations were formed using the regression analysis method. If no relations were detected or the regression model errors were quite big, model equations were formed using the adapted threshold autoregressive method and the algorithm proposed in the thesis.

The results of the studies performed led to the following main conclusions:

1. The models of economic processes time series, with constant or random fluctuations, additive outliers, level shifts, transitory changes, structural breaks, unstable dispersion, estimated by using traditional econometric methods are not suitable due to high model errors and parameter equations unsustainability.

2. The rapid economic, demographic, social and political changes have a significant impact on the structure of the time series of many country's economic indicators; therefore, usually linear time series estimation methods do not enable an 
accurate description of such time series - errors are higher than 10 pct. Such models can not be used in the analysis of economic processes due to low reliability.

3. Using modelled time series with different trend function and seasonal component types, imitating real time series, the following was established:

3.1. Before the modelling of economic time series, it is recommended to perform a structural analysis of endogenous and exogenous model variables, a primary correction of time series, and an extraction of non-observed components.

3.2. The spectral analysis of modelled time series showed that, irrespective of the type of the time series trend, seasonality or random component fluctuations, spectral analysis enables a precise estimation of the deterministic non-observed components of time series.

3.3. Comparative analysis of non-observed time series components estimation methods showed that both parametric and non-parametric methods describe non-observed components well enough: parametric methods are better used for the time series the variance of whose random component does not change in time, non-parametric methods - for those the variance of whose random component changes in time.

4. For complex nature economic indicators time series, a new modelling methodology was proposed - using time series correction, frequency analysis and threshold autoregressive methods, which has helped to improve econometric description of the economic processes.

5. The use of the ASETAR model order, threshold variable, bias and model equation parameter estimation algorithm, described in the thesis, enables a more precise description of non-linear behaviour, complex-nature real time series than the use of traditional linear methods. Moreover, ASETAR model errors are more stable, and their variance is considerably smaller.

6. The most common form of nonlinearity test RESET is not appropriate for threshold nonlinearity detecting and may be used only as an information tool. Using SETAR-type models of the time series detection threshold nonlinearity F-test criterion given reliable results.

7. The model errors analysis showed that the estimation of model equations by using ASETAR method gives smaller, more stable and with lower dispersion errors for complex nature economic time series with non linear behaviour, comparing with a traditional linear time series methods.

\section{Economical investigation on country's economic indicators dynamics model adequacy in Lithuania}

In the third chapter of the thesis, the task of compiling the model of the key Lithuanian economic indicators is solved based on the studies described in the previous chapters and using the model equation formation algorithm proposed. The results obtained are presented by, first of all, outlining the model structure and the factors determining the 
choice of model equation variables and drawing up equation specifications with probable parameter signs; then, model equations for economic indicators with estimated parameters are provided. A calculated absolute percentage error, a determination coefficient reflecting the adequacy of model equations, Durbin-Watson statistics measuring the autocorrelation of residuals and the significance of model equation parameters are provided next to each estimated equation. To avoid the expansion of the volume of the thesis, only a few estimated equations are presented in the chapter; the rest of the estimated equations are presented in Annex 1.

The analysis of other countries' economic modelling experience showed that part of the models are compact, including only the key economic indicators, and the main purpose of such models is the expeditious reliable assessment and forecast of the economic situation. The other part of the models, comprised of a larger number of modelled economic indicators, may yield more detailed results; however, due to a large number of component variables, the preparation of such analysis and forecasts takes much longer time. In the thesis, a decision was made to achieve balance between the former and the latter types of models. The main aim of this model is the expeditious provision of detailed Lithuanian economic analysis and forecasting results. Nevertheless, it is not difficult to expand the model, when needed.

The model provided in the thesis covers the key country's economic indicators. The model is comprised of five parts: production, prices, trade, income, and employment (see Fig. 3.1). The model may be used for studies into and assessment of the country's economic situation, quantitative analysis of economic indicators, economic forecasts.

The main endogenous variables of the model are as follows: value added, harmonised index of consumer prices, producer, import and export price indices, domestic demand for goods, imports, exports, national budget revenue, income of legal and natural persons, employed population, and the number of hours worked.

In the process of forming model equations, account was taken of economic meaningfulness, model equation errors and econometric validity. The indicators chosen to be the model's exogenous variables are those having an economically explainable impact on the modelled endogenous variable. Then, the correlation coefficients of the indicators selected are estimated. If an exogenous variable significantly correlates with the endogenous one, it is included in the model. When the selection of explanatory variables is completed, a check is run to figure out whether they are not interdependent. If multicollinearity is present, the coefficient estimates obtained will be incorrect. Therefore, a task of selecting the exogenous variables which will ensure that the classical regression assumptions are satisfied is solved.

For the modelling of complex-nature time series or endogenous variables for which no proper explanatory variables were found and/or the model errors exceed 5 per cent, a new adapted threshold autoregressive method is proposed in the thesis, when - before the model is compiled - the non-observed components of time series are assessed for the modelled indicators.

Further in the paper, the key model equation formation principles and specifications are provided.

Production. Production indicators were modelled taking into account the key factors affecting production. 
The more production factors are consumed, the more goods are produced or services are provided. However, the impact of factors influencing production depends on the length of the period analysed. There are more possibilities for increasing the output in the long-term than in the short-term period because over a long period all production factors change, while over a short period some production factors remain unchanged or change just marginally. In the long-term period, the output depends not only on labour but also on changes in capital - because as the output changes, investment and savings, which are the components of capital, change accordingly. In the short-term period, some of the production factors cannot change fast; therefore, they are invariable. For example, capital is accumulated throughout a long period, and its benefit is lasting; meanwhile, investments usually just replace depreciated capital or supplement it. Therefore, in a general short-term overview, capital is usually considered to be a constant, which limits changes in the output. However, if one of the production factors does not change significantly, the output will depend on another factor - labour. Since the movement of the labour force on the market is a permanent phenomenon, this factor may be considered as a rapidly changing production factor. Therefore, changes in production in the short-term period are possible only on condition that there are changes in the labour factor. However, the increase in the output through the increase in labour costs has a limit - when marginal labour costs exceed the benefit. In such case, the increase in the labour factor is no longer beneficial; therefore, it is not possible to achieve a constant and stable output growth just by increasing labour costs.

In the thesis, the modelling of the value added of individual production activities is based on a general case of a production function:

$$
Y(t)=A \cdot \mathrm{F}\left(x_{1}(t), x_{2}(t), \ldots, x_{m}(t)\right) .
$$

Where $Y(t)$ - value added, $x_{1}(t), x_{2}(t), \ldots, x_{m}(t)$ - factors influencing the production process, $A$ - total productivity of production factors.

Production functions are estimated based on the following assumptions:

- $\quad$ given the increase in the costs of a certain factor, when other costs are constant, a marginal growth in the output is achieved;

- there is a possibility of replacing and supplementing the production factors used without changing the output.

The key objective of the thesis is to perform a short-term analysis of the country's economy; therefore, closer attention in estimated equations was devoted to labour indicators: number of hours actually worked and employed population. The results of correlation analysis were used to select a labour indicator - either the number of employed persons (employed population) or the average monthly number of hours worked.

Since there are no estimated and officially published time series of gross capital by economic activity in Lithuania, a modified production function was used for the description of production indicators, which, instead of capital, included the variables influencing its changes - investment in tangible fixed assets by purpose and foreign direct investment. Some equations additionally included equity and changes in the sales of goods and services. 
To analyse the real time series of the national economy, various modifications of the production function were used in the thesis. To obtain as accurate and reliable results as possible, both additive and multiplicative production function model equations were formed. After the estimation of the production function in individual economic activities, the factors that had determined the economic changes in the country were analysed.

In the production section, the gross value added is modelled by 21 economic activities. The value added equation specification:

$$
Y=f_{Y}\left(\begin{array}{c}
L, I, X_{7}, X_{5} \\
+
\end{array}\right) .
$$

Where $Y$ - value added, $L$ - labour, $I$ - investment, $X_{7}$ - equity, $X_{5}$ - income from the sale of goods and services.

Employment. One of the main factors affecting production in the short-term period is labour, while this indicator, in turn, directly depends on the number of able-bodied residents and their motivation for active labour market participation. Therefore, a decision was made to, first of all, perform an analysis of the labour supply and demand in Lithuania.

When taking a decision on the number of employees to be hired, enterprises maximise their profit, which equals the value of the goods produced or services provided minus costs. To calculate the amount of labour maximising profit, enterprises compare the benefit of hiring an additional employee against costs. Here, costs refer to expenditure on the employee's wage, benefit - the value of the output produced by that additional employee. If the benefit exceeds the costs, the additional employee will increase the enterprise's profit; hence it is beneficial for the enterprise to hire more employees.

The overall labour demand is influenced by the same factors as in the case of a single enterprise; therefore, this theory may be used not only for one enterprise but also for macroeconomic analysis - creation of labour demand models for individual economic activities.

In the process of analysing the labour demand, one must simultaneously analyse the labour supply. The labour supply is formed by people of working age, considering and estimating the benefits and cost of work. The main benefit of work is the possibility to consume goods and services in exchange for earned income, while the cost of work is the loss of leisure time. The overall increase in the labour supply may be affected by just a few factors: increase in real earnings, increase in the working-age population, decrease in the inactive population.

In the thesis, the labour supply and demand is estimated by forming equations for hours actually worked and the number of persons employed in individual economic activities. The labour supply and demand equations specification are provided below.

$$
\Pi=f_{\Pi}\left(\begin{array}{c}
P_{G}, \underset{+}{Y}, \underset{-}{W}, X_{+} \\
+
\end{array}\right) .
$$

Where $\Pi$ - labour demand, $P_{G}$ - producer price indices for the production sold on the Lithuanian market, $Y$-value added, $W$-average monthly gross earnings, $X_{1}$ - employed population. 


$$
L S=f_{U}\left(\begin{array}{cc}
P C & X_{2} \\
+ & -
\end{array}\right) .
$$

Where $L S$ - labour supply, $P C$ - consumption of goods and services, $X_{2}$ - number of hours actually worked.

Prices. Production costs are comprised of the values of all the production resources (labour, capital, etc.) consumed. To achieve economic efficiency, producers have to estimate their expenditure on the production factors used. If there is a change in production factor prices, production costs also change. In that event, producers have to solve the task of optimising the production factors used anew or reconsider the prices for the goods produced or services provided. Large price fluctuations encumber the relative estimation of changes in prices for goods and services, cause deviations from efficient resource distribution, redistribution of assets and income, contribute to an increased investment risk. One of the main production factors in the short-term period is labour. Labour compensation makes up a rather large proportion in production costs. Production, employment, earnings and prices are directly cyclically connected. Although labour makes up a considerable proportion in production costs, other costs incurred by producers must also be taken into account. Apart from the costs incurred by producers, a decision on product prices is influenced by the market - household and general government final consumption, amount of the output sold, investment, exports.

Price stability is the best tool of monetary policy, which can contribute to two other important economic objectives - economic growth and job creation. During the last decade, both deflation and high inflation periods were observed in Lithuania, which made a negative impact on the country's economic stability. The thesis analysed the correlation between various factors and inflation changes in Lithuania.

Inflation is observed when the overall demand exceeds the overall supply. In the long-term period, the main factor affecting the overall demand is the amount of money. Therefore, the final consumer price equation includes additional regressors, reflecting the purchasing power of consumers. One of such regressors is earnings. However, given the intensification of emigration processes and the growth in the labour income from abroad, observed in recent years, earnings do not fully reflect the purchasing power of Lithuanian consumers. Therefore, after checking significance, compensation of employees credit and the amount of money were included in model equations.

Consumer price model equations are formed for twelve different groups, classified according to the Classification of Individual Consumption by Purpose (COICOP), prepared by the Organisation for Economic Co-operation and Development (OECD). Estimated indices are aggregated using the Laspeyres formula and a weighting system developed and annually updated by Statistics Lithuania.

Equation specifications of prices are provided bellow.

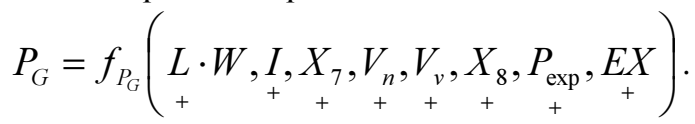

Where: $P_{G}$ - producer price indices for the production sold on the Lithuanian market, $L-$ labour, $W$ - average monthly gross earnings, $I-$ investment, $X_{7}$ - equity, $V_{n}-$ 
household consumption expenditure, $V_{v}$ - general government consumption expenditure, $X_{8}$ - production sold, $P_{\exp }-$ export price index, $E X$ - production exported.

$$
P_{V}=f_{P_{V}}\left(\begin{array}{c}
P_{G}, V_{n}, V_{v}, P_{i m}, P B, W,+_{+}, D_{+} \\
+
\end{array}\right)
$$

Where $P_{V}$ - harmonised indices of consumer prices, $P_{G}$ - producer price indices for the production sold on the Lithuanian market, $V_{n}$ - household consumption expenditure, $V_{v}$ - general government consumption expenditure, $P_{i m}$ - import price indices, $P B(t)-$ monetary basis: cash in circulation, current accounts and required reserves of credit institutions, $W$ - average monthly gross earnings, $D P(t)$ - compensation of employees credit.

Income. The income of any entity has two main characteristic functions: consumption (satisfaction of current needs) and saving (deferment of consumption to other periods - for the satisfaction of future needs). Income may take two forms: in cash and in kind. In the thesis, modelled income is broken down into personal income, income of economic entities, and national budget revenue.

The sources of personal income may be broken down by nature of income into three groups: market, redistribution system, and other persons' support. Since for more than half of households the main source of income is income from employment, and earnings is the best reflection of income from employment, a decision was made to include this indicator in the model. A major portion of households with social benefits as the main source of income is made up of pension beneficiaries; therefore, an average state social insurance old-age pension equation was also formed. No other quarterly indicators reflecting personal income were found in Lithuania.

Reliable regressors for the modelling of the average state social insurance old-age pension were not found; therefore, this indicator was modelled using an adapted SETAR model.

Statistics Lithuania collects, systemises and processes financial data on enterprises. In this section, a model equation was formed for the sum of sales and other operating income of enterprises.

In Lithuania, the national budget is comprised of the State budget and municipal budgets. It is comprised of taxes, other revenue, and European Union (EU) support. To describe the individual income tax, the number of employed persons and average monthly gross earnings are used. To estimate changes in the profit and social taxes, the total profit of enterprises is included, to estimate changes in taxes on goods and services - the value added generated and imports. Other national budget revenue and EU support time series are modelled using the adapted threshold autoregressive model, discussed in the thesis.

Equation specifications of income indicators are provided bellow.

$$
W=f_{W}\left(\begin{array}{c}
P_{V}, U_{+} n \\
+
\end{array}\right) .
$$

Where $W$ - average monthly gross earnings, $P_{V}$ - harmonised index of consumer prices, $U n$ - unemployment rate. 


$$
X_{5}=f_{X_{5}}\left(\begin{array}{c}
Y, P_{G} \\
+
\end{array}\right) \text {. }
$$

Where $X_{5}$ - income from sales, $Y$ - value added, $P_{G}$ - producer price indices for the production sold on the Lithuanian market.

$$
B=f_{B}\left(\begin{array}{c}
X_{1}, W \\
+ \\
+
\end{array}, \bar{X}, \underset{+}{Y}, \begin{array}{l}
I M \\
+
\end{array}\right) .
$$

Where $B$ - national budget revenue, $X_{1}$ - employed population, $W$ - average monthly gross earnings, $\bar{X}$ - enterprises' profit from economic operations, $Y$ - value added, $I M$ - imports.

Trade. In the thesis, trade results are analysed through the prism of supply of and demand for goods and services. Domestic demand is directly formed by households and the general government; moreover, since Lithuania is a small open economy, account must be taken not only of domestic trade but also of exports and imports.

The demand for goods is affected by multiple factors: price changes, part of the consumer budget allocated for the acquisition of goods, time. Meanwhile, supply is, first of all, determined by time, then - by the existence of competitive goods and by storage possibilities. The supply of end-use products is formed by producers, influenced by the current demand for goods and services. Meanwhile, traders engaged in imports analyse the current demand and form the supply of goods and services which are not produced or provided in Lithuania or import competitive goods or services.

Investment in production affords an opportunity for producers to produce more output with the same resources, i.e. increase the supply, while the introduction of new technologies often allows cheapening the production process, thus enhancing the competitiveness of and demand for products. Consumption depends on income; therefore, household and general government expenditure is modelled using income and other monetary indicators. To describe household consumption, apart from income data, data on the turnover of retail trade and catering enterprises are used.

Investment directly depends on two factors: economic entity's profit and interest rates. Since sales depend on consumption, the model equation includes private and general government consumption. If consumption is growing, the sales of goods and services by enterprises are also growing, which, in turn, results in a profit growth. However, if one wants to increase the output, one has to increase investment. Since it is not always that the profit earned is sufficient for investment, many enterprises take out loans. For that reason, the model equation includes the volume of loans and interest rates. If those are high, it is possible that the benefits from investment will be smaller than interest, and enterprises decide not to invest. Since there is not enough data on all types of investment in Lithuania, the thesis focuses on the modelling of investment in tangible fixed assets.

To describe imports, an import demand function was formed using consumption, investment and exports variables. Imports also depend on production and the real exchange rate. An increase in the real exchange rate results in a relative growth in prices for domestic goods, as compared to the imported ones, which, in turn, opens up import 
growth possibilities; and vice versa: a decrease in the real exchange rate results in a relative drop in prices for domestic goods, as compared to the imported ones. In Lithuania, there is no estimated and officially released real exchange rate; moreover, it is quite hard to estimate precisely because it is related to the nominal exchange rate and to prices on the domestic and foreign markets. Therefore, in the estimation of imports, it was decided to use the nominal exchange rate of the litas vis-à-vis the currencies of the foreign countries accounting for the major portion of imports into Lithuania (Russia, Poland, and Latvia).

The products produced in Lithuania are exported to many countries. To provide an accurate description of exported products, an analysis of all those countries' markets would have to be made, which is not the purpose of the thesis. Therefore, to describe changes in exports, the value added generated, the indicators of consumption of goods in Lithuania, the export price index are used, while the impact of changes in exchange rates on exports is studied by including the exchange rate of the litas vis-à-vis the currencies of the foreign countries accounting for the major portion of exports from Lithuania in the equation.

Equation specifications of trade indicators are provided bellow.

$$
V_{n}=f_{V_{n}}\left(\underset{+}{W,} \underset{+}{D P}, M_{+} P\right)
$$

Where $V_{n}$ - private consumption, $W$ - average monthly gross earnings, $D P$ compensation of employees credit, $M P$ - turnover of retail trade and catering enterprises.

$$
V_{v}=f_{V_{v}}\left(\begin{array}{c}
B, Y_{+}, P B \\
+
\end{array}\right) .
$$

Where $V_{v}$ - general government consumption, $B$ - national budget revenue, $Y_{O}$ - value added generated in public administration and defence, compulsory social security, $P B-$ monetary basis: cash in circulation, current accounts and required reserves of credit institutions.

$$
I=f_{I}\left(\underset{+}{\bar{X}}, \underset{+}{P A}, \underset{-}{P N}, X_{+}\right) .
$$

Where $I$ - investment in tangible fixed assets, $\bar{X}$-profit from economic operations, $P A$ - volume of loans, $P N$ - interest rate, $X_{1}$ - employed population.

$$
I M=f_{I M}\left(\begin{array}{c}
V_{n}, V_{v}, I, E X, \bar{\xi}_{R U}, \bar{\xi}_{P L} \\
+++_{+}
\end{array}\right) .
$$

Where $I M$ - imports, $V_{n}$ - private consumption, $V_{v}$ - general government consumption, $I$ - investment, $E X$ - exports, $\bar{\xi}_{R U}(t)$ - exchange rate of the litas vis-à-vis the Russian rouble, $\bar{\xi}_{P L}(t)$ - exchange rate of the litas vis-à-vis the Polish złoty.

$$
E X=f_{E X}\left(\begin{array}{c}
V_{n}, V_{v}, I, P_{+} P_{+}, \bar{\xi}_{L V} \\
-{ }_{-}
\end{array}\right) .
$$

Where $E X$ - exports, $V_{n}$ - private consumption, $V_{v}$ - general government consumption, $P_{\text {exp }}$ - export price index, $\bar{\xi}_{L V}(t)$ - exchange rate of the litas vis-à-vis the Latvian lat. 
The benefit of this methodology for the enhancement of the accuracy of economic indicator model equations and forecasts has been estimated and is presented in tables 3.2 and 3.3 of the thesis.

The third chapter of the thesis describes, in brief, the software developed by the author of the thesis, enabling a simultaneous estimation of economic trends in the country and the total of economic indicators, production of forecasts, with or without using primary assumptions, as well as the construction of various economic scenarios.

The practical results of research lead to the following conclusions:

1. Empirical studies were carried out in case of Lithuania, for checking proposed methodology in practice. The chapter provides the country's main economic indicators of practical modelling, according to the methodology described in the second section of the results. Practical results show that the proposed method enables enough accurate assessment of the country's economic processes, which received an average absolute relative error of 2.7 percent. Therefore, the proposed methodology is appropriate for modelling of country's state of the economy and the prospects, for analyzing and forecasting.

2. The small errors (average error of model equations is equal 2.7 pct, average economical prospects error $-3,1$ pct.) proves, that created country's economic indicators dynamics model can be reliably applied for investigation of the country's economic status, the quantitative analysis of economic indicators and the prediction of further economic situation.

3. Lithuanian production indicator in some economic activities did not obtain reliable results, by using the production function factors. Errors in different economic activities exceed 10 percents. Insufficient statistical information that measure economical processes and other properties of Lithuanian economy may take influence to results. Additional regressors included in models improve the results - errors decrease to average 1 percent and improve the accuracy of predictions.

4. The original software tools developed for country changes analysis may be used for the identification of the changes of the main indicators, depending on the changes affecting them, the production of economic processes forecasts, and the construction of various economic scenarios with different primary assumptions.

\section{General conclusions}

1. The analysis of the theoretical and practical assumptions and possibilities for the modelling of the country economic indicators, the Lithuanian and other countries' modelling experience showed that some of the existing models may be used in Lithuania just fragmentarily. The use of most of the existing models is limited by the lack of relevance and insufficient coverage. The detailed simultaneous analysis of the country's economy and production of forecasts requires an up-to-date all-round model of the key economic indicators.

2. The proposed structure of the model, which includes the main indicators of the economy and consists of five components: production, employment, prices, income and 
trade. The model can be applied for a complex analysis of country economic situation, qualitative analysis of economic indicators and estimation of the economic prospects.

3. Various economic demographic, social, political and calendar changes significantly influence to the structure of many economic indicators - regular and random fluctuations, outliers, and structural breaks occur. After comprehensive initial analysis of leading economic indicators time series was identified that many country's economical indicators are affected with seasonality and other confusing components additive outliers, transitory changes, level shifts, significant calendar effects. The time dependence of the dispersion and nonlinear behaviour is also observed in some time series. Therefore, most frequency used linear time series techniques are not appropriate for such time series.

4. The results of comparative analysis of economic indicators modelling methods, which was carried out with real and simulated time series of modelling indicators, enabled to propose a new methodology for the estimation and forecasting of country's economic indicators, with a typical or a complex nature behaviour, to calculate a shortterm and medium-term forecasts, to perform complex analysis of the country's economy, to analyse the impact of various changes on the national economy, to evaluate consequences for the country's economic status and prospects of changes, to construct various economic scenarios.

5. The studies performed and results of modelling prove that the new economic indicators modelling methodology, proposed in the thesis, enables an accurate assessment of the economic processes, due to a significant reduction in model equation and forecast errors (model error decreased from an average of 6.0 percent to 2.7 per cent.) and a low average error of perspective, which is equal to 3 percent, show this.

6. The software tools developed enable the complex analysis of changes in the leading country's economic indicators, preparation of reliable short-term and mediumterm forecasts, estimation of the impact of changes in economic indicators on the national economy, construction of various economic scenarios, depending on different economical assumptions. 



\section{Priedai $^{2}$}
A priedas. Modeliuotų laiko eilučių nestebimų komponenčių vertinimo paklaidos
B priedas. Adaptuoto SETAR specifikacija
C priedas. SETAR poklasių keitimo grafikai
D priedas. ASETAR ir ARIMA modelių iverčiu grafikai
E priedas. SETAR ir ARIMA modelių paklaidų grafikai
F priedas Ivertintos modelio lygtys ir grafikai
G priedas. Bendraautorių sutikimai teikti publikacijų medžiagą disertacijoje
H priedas. Autoriaus mokslinių publikacijų disertacijos tema kopijos

${ }^{2}$ Priedai pateikiami pridetoje kompaktineje plokšteleje 


\section{Nomeda BRATČIKOVIENE}

\section{ŠALIES EKONOMIKOS INDIKATORIŲ}

DINAMIKOS MODELIS

Daktaro disertacija

Socialiniai mokslai, Ekonomika (04S)

THE MODEL OF THE COUNTRY'S ECONOMIC INDICATORS DYNAMICS

\section{Doctoral Dissertation}

Social Sciences,

Economics (04S)

$20140113.12,25$ sp. 1. Tiražas 20 egz.

Vilniaus Gedimino technikos universiteto leidykla „Technika“,

Saulètekio al. 11, LT-10223 Vilnius, http://leidykla.vgtu.lt

Spausdino UAB „Ciklonas“,

J. Jasinskio g. 15, LT-01111 Vilnius 